\title{
The diplacanthid fishes (Acanthodii, Diplacanthiformes, Diplacanthidae) from the Middle Devonian of Scotland
}

\author{
Carole Burrow, Jan den Blaauwen, Michael Newman, and Robert Davidson
}

\begin{abstract}
The Diplacanthiformes are a clade of acanthodian fishes which were widespread during the Middle and early Late Devonian. They are best represented in the Middle Devonian, by articulated fossils, fin spines, and abundant scales, the latter particularly from northern Europe. Three species of diplacanthid diplacanthiforms, Diplacanthus crassisimus, Diplacanthus tenuistriatus, and Rhadinacanthus longispinus, are found in Middle Devonian (Eifelian-Givetian) assemblages of articulated fish in northern Scotland. Our detailed study of the dermal structures and endoskeletal shoulder girdles in these fish supports the validity of Rhadinacanthus as a separate genus from Diplacanthus, with the two being differentiated by spine morphology, scale morphology, and histology, and shape and form of the pectoral girdle. In Orkney and Caithness, $D$. crassisimus first occurs in the Thursius macrolepidotus vertebrate biozone and disappears by the Millerosteus minor + Thursius pholidotus vertebrate biozone. Diplacanthus tenuistriatus and $R$. longispinus range from the Coccosteus cuspidatus biozone to the end of the Millerosteus minor + Thursius pholidotus biozone. Through comparing the results of our detailed work on the morphology and histology of fin spines and scales from the articulated fish with diplacanthid taxa based on isolated scales and fin spines from the Baltic region, Belarus, and Severnaya Zemlya, we recognize many of the latter taxa from contemporary deposits as junior synonyms of the Scottish species. Phylogenetic analysis of selected gnathostome genera shows the diplacanthiforms Diplacanthus, Rhadinacanthus, Uraniacanthus, and Culmacanthus form a well-supported clade within a larger clade comprising all acanthodian taxa plus a monophyletic Chondrichthyes.
\end{abstract}

Carole Burrow. Geosciences, Queensland Museum, 122 Gerler Rd, Hendra, Brisbane, Queensland 4011, Australia. carole.burrow@gmail.com Jan den Blaauwen. University of Amsterdam, Science Park 904, 1098 XH, Amsterdam, Netherlands. J.L.denBlaauwen@uva.nl Michael Newman. Vine Lodge, Vine Road, Johnston, Haverfordwest, Pembrokeshire, SA62 3NZ, United Kingdom. ichthyman@btinternet.com Robert Davidson. 35 Millside Road, Peterculter, Aberdeen, AB14 0WG, United Kingdom. Bob.Davidson@nexencnoocltd.com

Keywords: Diplacanthus; Rhadinacanthus; Caithness; Orkney; histology; phylogeny

Submission: 20 September 2015 Acceptance: 8 February 2016

Burrow, Carole, den Blaauwen, Jan, Newman, Michael, and Davidson, Robert. 2016. The diplacanthid fishes (Acanthodii, Diplacanthiformes, Diplacanthidae) from the Middle Devonian of Scotland. Palaeontologia Electronica 19.1.10A: 1-83 palaeo-electronica.org/content/2016/1398-scottish-diplacanthid-fishes 


\section{INTRODUCTION}

The diplacanthiforms are a group of acanthodians which were widespread during the Middle and early Late Devonian, being recorded from all continents: Europe (Agassiz, 1844); North America (Woodward, 1892); Australia (Burrow, 2002); South America (Burrow et al., 2003); Antarctica (Young and Burrow, 2004); Africa (Gess, 2001; Derycke and Goujet, 2011); and possibly China (Burrow et al., 2000). Whereas Berg (1940) considered the group as an Order, Denison (1979) demoted them to Family level, within the Order Climatiiformes. However, the Climatiiformes are no longer recognized as a clade (e.g., Hanke and Wilson, 2004; Brazeau, 2009; Burrow and Turner, 2010), whereas many recent analyses show the diplacanthiforms as a well-characterized monophyletic group (Burrow and Turner, 2010, figure 7A, 7B, Culmacanthus stewarti+Diplacanthus horridus+Milesacanthus antarctica+Gladiobranchus probaton+Tetanopsyrus breviacanthus; Davis et al., 2012, figure 4a; Zhu et al., 2013, supplementary figures 2a, 3, 6b, 7a, Tetanopsyrus+Culmacanthus+Diplacanthus+Gladiobranchus+Rhadi nacanthus).

The oldest diplacanthiforms known from articulated fossils are earliest Devonian Uraniacanthus spp.: type species $U$. spinosus Miles, 1973a from England, U. curtus (Powrie, 1870) (originally assigned to Euthacanthus, reassigned by Newman et al., 2012) from Scotland, and U. probaton (Bernacsek and Dineley, 1977) (originally assigned to Gladiobranchus, also reassigned by Newman et al., 2012) from Canada; plus Tetanopsyrus spp. from Canada (e.g., Hanke et al., 2001). Most known taxa, however, are Middle Devonian, represented by articulated fossils and fin spines, and as the most abundant acanthodian scales in Middle Devonian microvertebrate assemblages from northern Europe (e.g., Valiukevičius, 2000). Despite articulated specimens of Diplacanthus spp. from the Middle Devonian of Scotland and Frasnian of Canada first being described in the 1800 s, only rarely has work been undertaken to better understand their anatomy (Watson, 1937; Miles, 1973a; Gagnier, 1996) and the morphology and histology of their squamation (Gross, 1947; Denison, 1979, figure 21; Young, 1995).

Here we provide detailed descriptions of the general anatomy and morphology and histology of dermal elements and the endoskeletal shoulder girdle of the Scottish Middle Devonian diplacanthids, and discuss their biostratigraphical and biogeographical distribution. We also undertook a cladistic analysis of selected gnathostome taxa based on other recent analyses (Zhu et al., 2013; Dupret et al., 2014), adding two extra acanthodian taxa Nerepisacanthus denisoni Burrow, 2011 and Gyracanthides murrayi Woodward, 1906. We revised data codings for acanthodians based on our work on the Scottish diplacanthids and other recent publications.

All specimens studied are housed in the collections of the National Museums of Scotland, Edinburgh (NMS G), the Natural History Museum in London (NHM P), the Queensland Museum (QM $F)$, and the Institute of Geology at Tallinn University of Technology (GIT).

\section{HISTORY OF RESEARCH ON THE DIPLACANTHIDS OF SCOTLAND}

\section{Diplacanthus crassisimus (Duff, 1842)}

The first publication on a Scottish diplacanthid was a brief description and figure of an unnamed 'ichthyolite' by Hugh Miller (1841, plate 8.2 ) in the first edition of his classic work "The Old Red Sandstone." This specimen NMS G.1953.4.4 (counterpart $=$ NMS G.1859.33.3) was the first articulated example of the type species Diplacanthus crassisimus to be figured; the species is by far the most common articulated diplacanthid found in Scotland. Hugh Miller was aware that Louis Agassiz was preparing a monograph describing the Scottish Devonian fish and presumably did not want to steal priority. Later editions of Miller's classic book had his figure captioned as Diplacanthus striatus, the name that Agassiz assigned to the species in his manuscript. However, priority was taken by Patrick Duff who provided a short description with a restoration of the species Diplocanthus crassisimus (Duff, 1842, plate 10.2) that bears an uncanny resemblance to Miller's figure. Duff (1842) had wrongly transcribed the genus name from Agassiz' manuscript. Duff (1842, plate 11.3) also figured NMS G.1891.92.333 (Figure 1.1) from Tynet Burn in a very poor drawing, and it is this specimen which is regarded as the holotype. Agassiz (18441845) published his own fuller account of the species under the names Diplacanthus striatus, $D$. striatulus, and D. crassispinus. Agassiz (1844-1845, plate D.3) produced a schematic restoration of the genus Diplacanthus. M'Coy (1848) raised a new species Diplacanthus gibbus based on some poorly preserved specimens from Orkney and later figured one of the "better" specimens (M'Coy 1855, plate 2B.4). Traquair (1888) could see no valid character differences between $D$. crassispinus, $D$. 


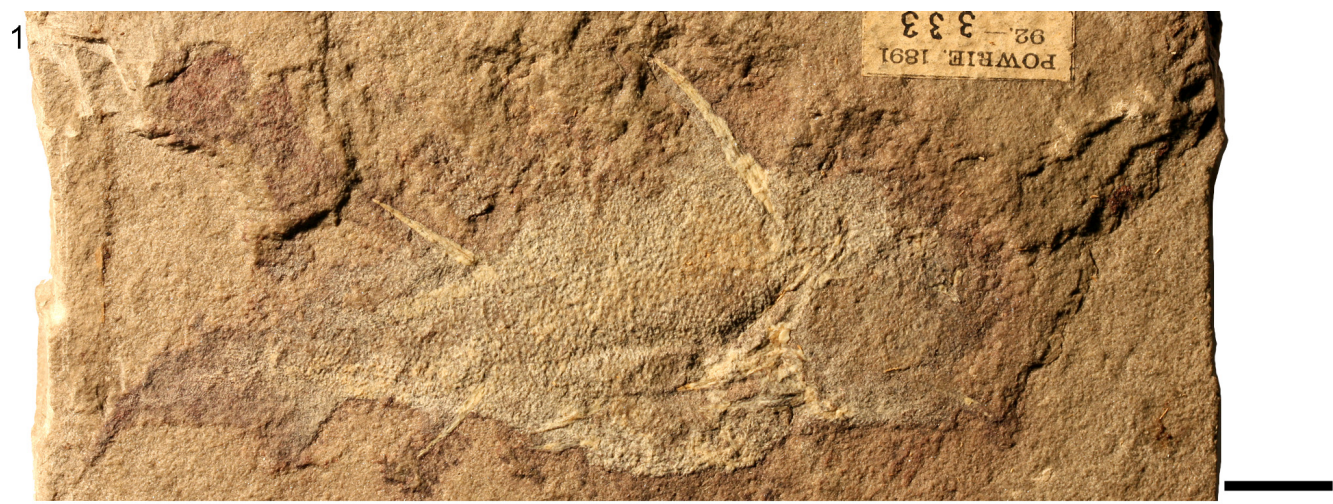

2

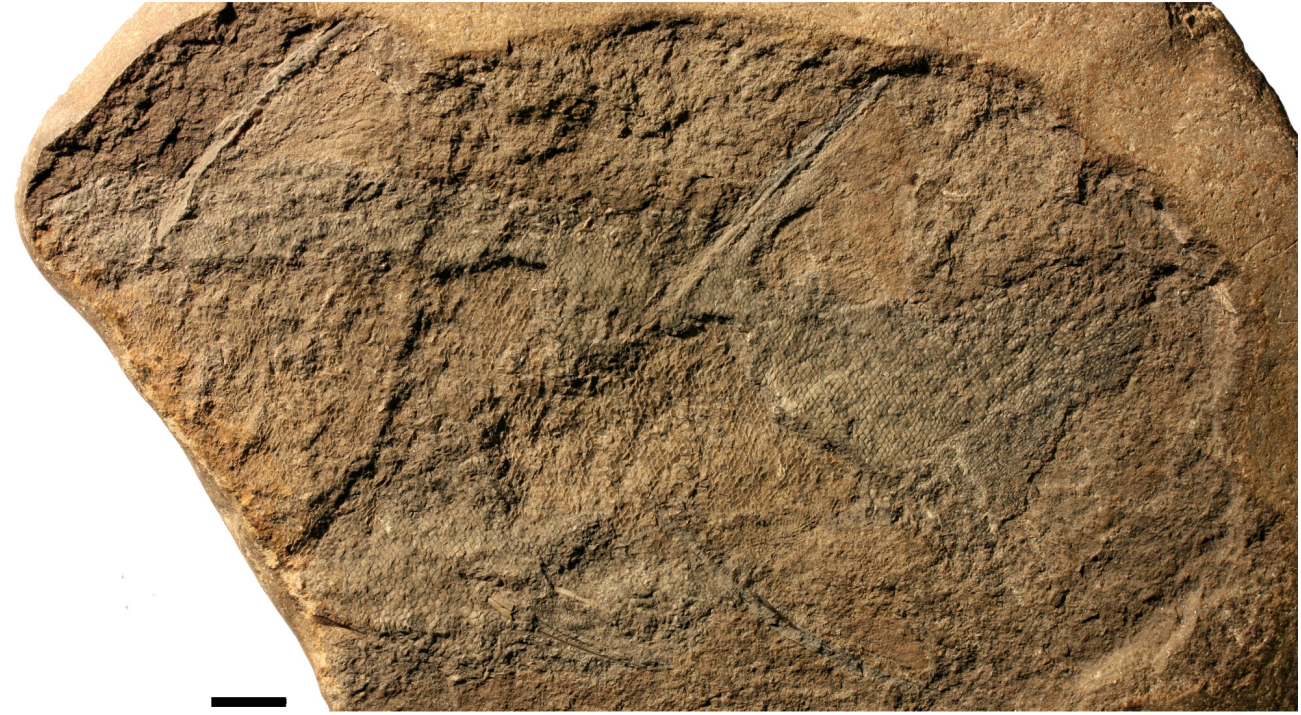

4

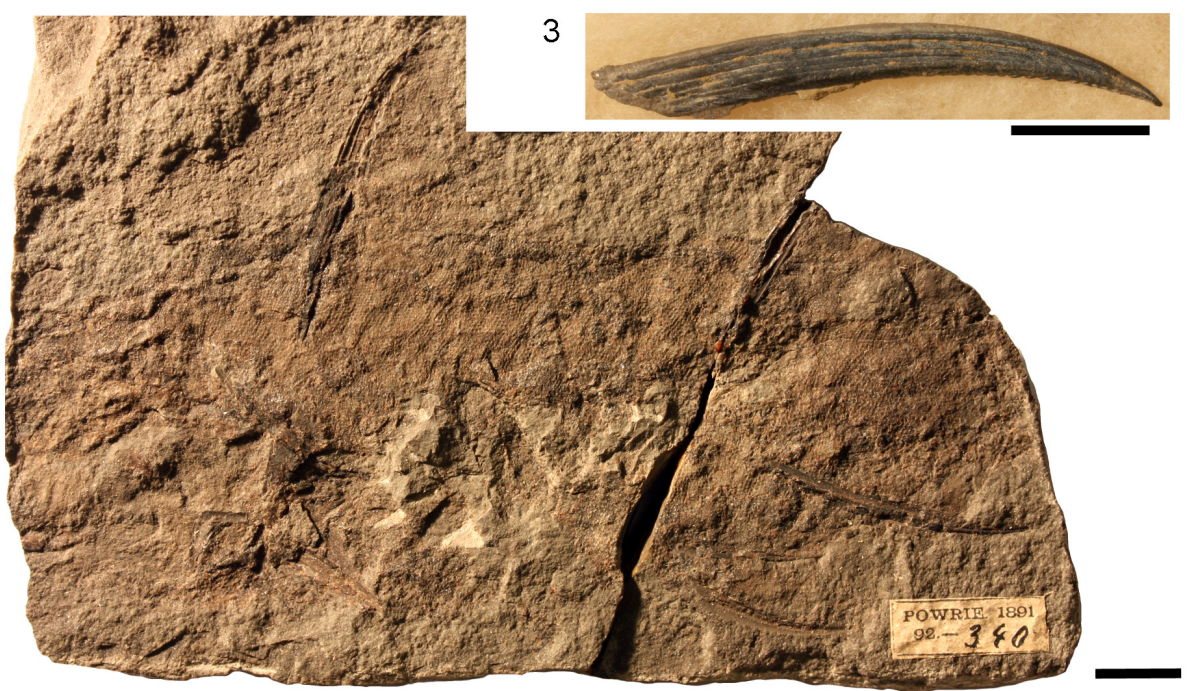

FIGURE 1. Type specimens of Scottish Middle Devonian diplacanthids: 1, Diplacanthus crassisimus (Duff, 1842) holotype NMS G.1891.92.333, from Tynet Burn, Moray; 2, Rhadinacanthus longispinus (Agassiz, 1844) holotype NMS G.1953.4.3, from Cromarty, Ross and Cromarty; 3, Homacanthus borealis holotype spine NMS G.1892.91.1, from Lybster, Caithness; 4, Diplacanthus tenuistriatus (Traquair, 1894) syntype NMS G.1891.92.340, from Gamrie, Banffshire. Scale bars equal $1 \mathrm{~cm}$. 
gibbus, $D$. striatulus, and $D$. striatus, considering all differences between the species were due to preservation; he synonymized all the forms as $D$. striatus, which had page priority in Agassiz's (1844-1845) work, rather than D. crassisimus, which had chronological priority. The last reconstruction of Diplacanthus in the $19^{\text {th }}$ century was by Traquair (1895, plate 2.1), showing D. crassisimus in a life-like pose. Watson (1937) gave a detailed description of the species, and his figure 14A is the restoration most commonly found in text books. Watson's account was the last full description of the species, although Miles (1973a) described the shoulder girdle region in much more detail than previous workers. Davidson and Trewin (2005) provided new information on the remains of internal organs of this species, preserved as dark stains. Diplacanthus striatus was often used as the species name (in particular, by Miles 1966, 1973a), but $D$. crassisimus has priority.

\section{Rhadinacanthus longispinus (Agassiz, 1844)}

The holotype (NMS G.1953.4.3; Figure 1.2) of this species is an articulated fish from Cromarty, first briefly mentioned by Hugh Miller (1841) in the first edition of "The Old Red Sandstone." Miller (1841, plate 8.1) described and captioned the specimen as another unnamed 'ichthyolite.' This specimen was also one of the two syntypes figured by Agassiz (1844-1845, plate 14.8) when he raised Diplacanthus longispinus. The other syntype figured by Agassiz (plate 13.5) was reidentified as Diplacanthus crassisimus by Andrews (1982). M'Coy (1848) raised a new species Diplacanthus perarmatus based on poorly preserved specimens from Orkney, later figuring the best specimen he had at his disposal (M'Coy 1855, plate 2B.3). Traquair (1888) could see no specific character differences between $D$. longispinus and $D$. perarmatus and synonymized them by priority as $D$. longispinus. He also erected a new genus Rhadinacanthus for the species, based mainly on the assumption that there is only one pair of spines between the pectoral and pelvic spines. However, Woodward (1891) identified an anterior pair of relatively small admedian spines as well as the larger prepelvic pair and reverted to Diplacanthus as the genus name. Several authors including Gross (1973), however, have retained the genus Rhadinacanthus for this species, based on the differences in spine and scale morphology between $R$. longispinus and the other two Scottish diplacanthids $D$. crassisimus and $D$. tenuistriatus. Due to the rarity of $R$. longispinus it is not often figured in the literature. The last published description of the whole fish was by Woodward (1891).

\section{Diplacanthus tenuistriatus (Traquair, 1894)}

Diplacanthus tenuistriatus was first briefly described by Traquair as Homacanthus borealis based on a solitary pectoral fin spine NMS G.1892.91.1 (Traquair, 1892, plate 8; Figure 1.3) from Lybster, Caithness. Traquair (1894) raised the new species Diplacanthus tenuistriatus, which he distinguished from $D$. crassisimus by its greater size and the nature of its fin spines. Paton (1976) recognised $H$. borealis as a synonym of $D$. tenuistriatus, and it is surprising that Traquair did not also recognize the identical pectoral fin spines. Based on this chronology, $H$. borealis should have had priority and the species should be Diplacanthus borealis, but following ICZN rule 23.9.1, prevailing usage must be maintained because the senior synonym has not been used as a valid name after 1899 (rule 23.9.1.1), and the junior synonym has been used as its presumed valid name, in at least 25 works, published by at least 10 authors in the immediately preceding 50 years and encompassing a span of not less than 10 years (rule 23.9.1.2). Although $D$. tenuistriatus has been rarely mentioned in hardcopy publications, if webpage references are included then the species name fills the latter criterion.

Traquair (1894) did not figure any specimens or mention any registration numbers, but Paton (1976) identified the specimens Traquair described, listing them as syntypes NMS G.1859.33.90 (Figure 1.4; counterpart NMS G.1859.33.91) from Cromarty, Moray, NMS G.1892.8.6 (counterpart NMS G.1892.8.7) from Gamrie, Banff and NMS G.1891.92.340 from Gamrie, Banff. The Cromarty syntype, which was part of the Hugh Miller collection, was the first specimen Traquair observed, having been shown it by Charles Peach many years previously, before Traquair started working at the Royal Scottish Museum (Traquair, 1894).

\section{GEOLOGICAL SETTING}

The Middle Devonian deposits of the Orcadian Basin extend from the southern shores of the Moray Firth to the isles of Shetland. The deposits are cyclic, alternating between deep lake and fully exposed sediments. These cycles have been considered by a number of authors (e.g., Hamilton and Trewin, 1988; Astin, 1990) to be climate controlled with Milankovic periodicities. For the most part the basin at this time consisted of a series of moder- 
ately sized lakes, but at maximum high stand (at the Sandwick/Achanarras horizon) a very large lake filled most of the basin (Trewin, 1986). The geology and sedimentology of the Orcadian Basin is described in detail in numerous works (e.g., Trewin and Thirlwall, 2002 and references therein). Diplacanthid remains are found throughout most of the Orcadian Basin area, but not in Shetland. The oldest record is of Diplacanthus crassisimus in the Lybster Flagstone Formation in Caithness (Figure 2 ), although this is based on a solitary specimen. The stratigraphically equivalent Lower Stromness Formation in Orkney is fossil poor and D. crassisimus is unknown from this formation. This species becomes much more common in the overlying Sandwick and Achanarras fish beds and the equivalent Moray Firth nodule beds. It is also in these beds that Diplacanthus tenuistriatus and Rhadinacanthus longispinus first appear. These three species are particularly common in the nodule beds. These were laid down at a high stand of the Orcadian Lake when it transgressed a series of alluvial plains (Trewin and Davidson, 1999). Middle Devonian fossil remains are much rarer in the Moray Firth above the nodule beds horizon, with no diplacanthids known. Diplacanthus crassisimus disappears from the Orcadian Basin at the top of the Lower Rousay and Thurso Flagstones formations. The other two species disappear in the overlying Middle Rousay and Mey formations (Figure 2).

The best preserved, articulated fossils are found in the deep lake sediments. In Orkney and Caithness these sediments are varved flagstones which represent anoxic conditions, hence the better preservation (Trewin, 1986). The Moray Firth nodule sites were deposited in shallower water, but fish are still well-preserved in calcareous nodules (Trewin and Davidson, 1999). Fossil remains are also found in shallow lake deposits but these tend to be disarticulated, often as localized bonebeds. These bonebeds are often associated with stromatolite debris, plant fragment and coprolites (which often contain diplacanthid remains).

\section{MATERIALS AND METHODS}

Macro-photographs were taken using a Canon EOS 450D, and microphotographs were made under normal light using a Nikon Eclipse E400 microscope with a Sony Cyber-shot DSC-H5 camera. Images of thin sections were also made with the Cyber-shot and microscope adapter, combined with a Wild M3Z binocular microscope. Figures were compiled using Adobe Photoshop $₫$. Thin sections were made using epoxy resin to sta- bilize and secure specimens to glass slides, and manually ground using various sizes (down to four microns) of corundum powder. Material from Achanarras Quarry, Caithness, and Moray Firth nodule-bearing localities (particularly, Eddeton, Tynet Burn, Gamrie, Cromarty, and Eathie) and from isolated, small bone beds enriched in organic remains found in Caithness and Orkney were most suitable for this process. The material from the Sandwick fish bed tended not to be very translucent in thin section. Some fin spines and pectoral girdle elements were glued or covered with twocomponent polyester filler then serial sectioned using a $1 \mathrm{~mm}$ thick diamond saw. The various sections were photographed under water and drawn to produce reconstructions. Where thin section and serial section elements are preserved they are given suffixes to registration numbers to the original specimen (Appendix 1). For example, NMS G.2014.33.8, a pectoral girdle of Diplacanthus crassisimus, was sectioned thus to produce six thin sections, hence NMS G.2014.33.8.1-6.

The Sollas grinding method (Sollas, 1903) was used on some bone bed (e.g., NMS G.2014.15.1) and articulated material (e.g., NMS G.2014.44.4) although this method often totally destroys a specimen. Samples from other specimens were immersed in weak acetic acid to separate individual scales for scanning electron microscopy using an Hitachi Tabletop TM-1000 scanning electron microscope (SEM) housed in the Queensland Museum, Brisbane, Australia.

\section{SYSTEMATIC PALAEONTOLOGY}

\author{
Class ACANTHODII Owen, 1846 \\ Order DIPLACANTHIFORMES Berg, 1940
}

Remarks.- See Newman et al. (2012) for a revised diagnosis.

Family DIPLACANTHIDAE Woodward, 1891

Revised Diagnosis. Diplacanthiforms having scapulocoracoid with high scapular shaft extending dorsal to the lateral line, divided by a strong ridge into a postbranchial lamina and a posterior flange; dermal shoulder girdle with paired anterior plus paired pinnal plates; anterior dorsal fin spine longer than posterior dorsal spine; median, pectoral, and pelvic fin spines deeper than wide; spines with a main pulp canal and at least one accessory pulp canal; paired admedian spines and pectoral fin spines fused to, or articulating with, pinnal plates; anterior ventral plates fused to procoracoids; one pair of prepelvic spines; no prepectoral spines; dermal ornamented cheek plates lacking a sensory 


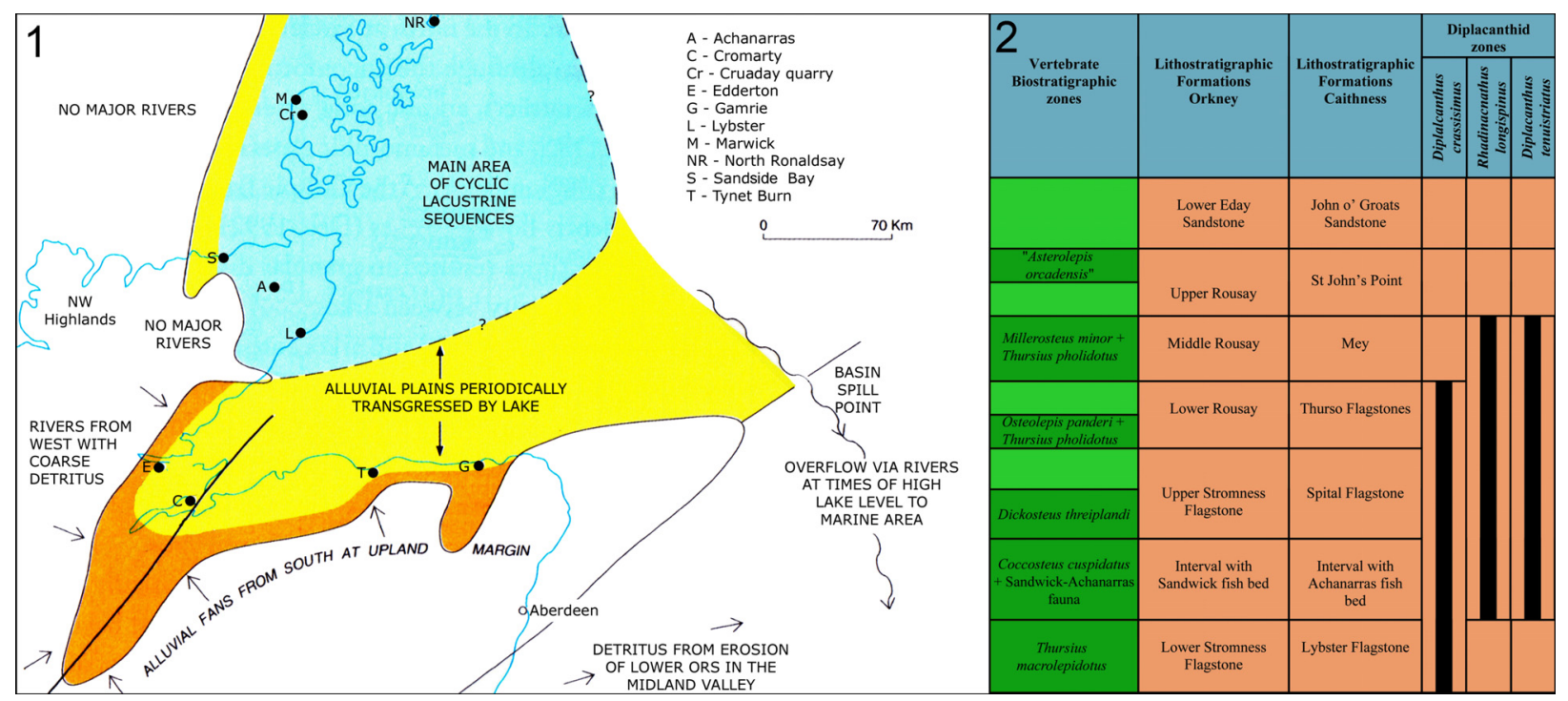

FIGURE 2. 1, Site map indicating the most important localities with Middle Devonian diplacanthids on northern Scotland; 2, biostratigraphic table of diplacanthid occurrences in the Orcadian Basin of northern Scotland.

canal; large circumorbital plates do not completely encircle the orbit; scale crowns ornamented with longitudinal converging or transverse ridges; low robust occlusal bone on each lower jaw.

\section{Genus DIPLACANTHUS Agassiz, 1844}

Type Species. Diplocanthus crassisimus Duff, 1842 , by original designation.

Revised Diagnosis. Dermal and endoskeletal pectoral girdle elements - pectoral and admedian spines, scapulocoracoid, procoracoid, pinnal and anterior ventral plates - articulating or fused as a single structure on each side of body; sides of fin spines with multiple longitudinal ridges; each eye encircled by a single long plate plus multiple short plates; high scales with a narrow neck, flat base and scale crowns ornamented with denticulated transverse ridges; scales with a network of canals opening out via pores on the crown and high on the posterior neck.

Included Species. Diplacanthus tenuistriatus Traquair, 1894; Diplacanthus kleesmentae Valiukevičius and Karatajūtè-Talimaa, 1986; ?Diplacanthus gravis Valiukevičius, 1988a; ?Diplacanthus poltnigi Valiukevičius, 2003 (Lochkovian; possibly Uraniacanthus sp.); ?Diplacanthus solidus Valiukevičius, 2003.

\section{Diplacanthus crassisimus (Duff, 1842)}

Figures 1.1, Figure 3, Figure 4, Figure 5, Figure 6, Figure 7, Figure 8, Figure 9, Figure 10, Figure 11, Figure 12 ichthyolite; Miller, pl. 8, fig. 2.
1842 Diplacanthus crassisimus Duff, 1842; Duff, p. 71, pl. 10, fig. 2; pl. 11, fig. 3.

1844 Diplacanthus striatus Agassiz; Agassiz, p. 34, 41, pl. 14, figs. 1, 2.

1844 Diplacanthus striatulus Agassiz; Agassiz, p. 34, 42, pl. 8, figs. 3, 4.

1844 Diplacanthus crassispinus Agassiz; Agassiz, p. 34, 43, pl. 8, figs. 1, 2, pl. 14, figs. $6,7$.

1844 Diplacanthus longispinus Agassiz, in part; Agassiz, pl. 13, fig. 5.

$1844 \quad H y b o d u s$ gracilis Eichwald; p. 827.

1845 Homacanthus gracilis (Eichwald); Agassiz, p. 153.

$1845 \quad$ Homacanthus arcuatus Agassiz; Agassiz, p. 113, 114, pl. 33, figs. 1-5.

1846 Hybodus gracilis; Eichwald, p. 279, pl. 1, figs. 12, 13.

1847 Diplacanthus striatus; Miller, pl. 8, figs. 2, 4.

$1848 \quad$ Diplacanthus gibbus M'Coy; p. 301.

1855 Diplacanthus gibbus; M'Coy, p. 584, pl. 2B, fig. 4.

$1859 \quad$ Diplacanthus striatus; Timbs, p. 142.

non 1881 D. striatus of Agassiz; Whiteaves, p. 160, 162.

$1888 \quad$ Diplacanthus striatus; Traquair, p. 512.

non 1889 Homacanthus gracilis, N. sp.; Whiteaves, 1888 , p. 96, pl. 10, fig. 4.

1890 Diplacanthus striatus, Ag.; Traquair, p. 482.

1891 Diplacanthus striatus Agassiz; Woodward, p. 24, text-fig. 3.

1892 Diplacanthus striatus (Ag.); Traquair, p. 37. 

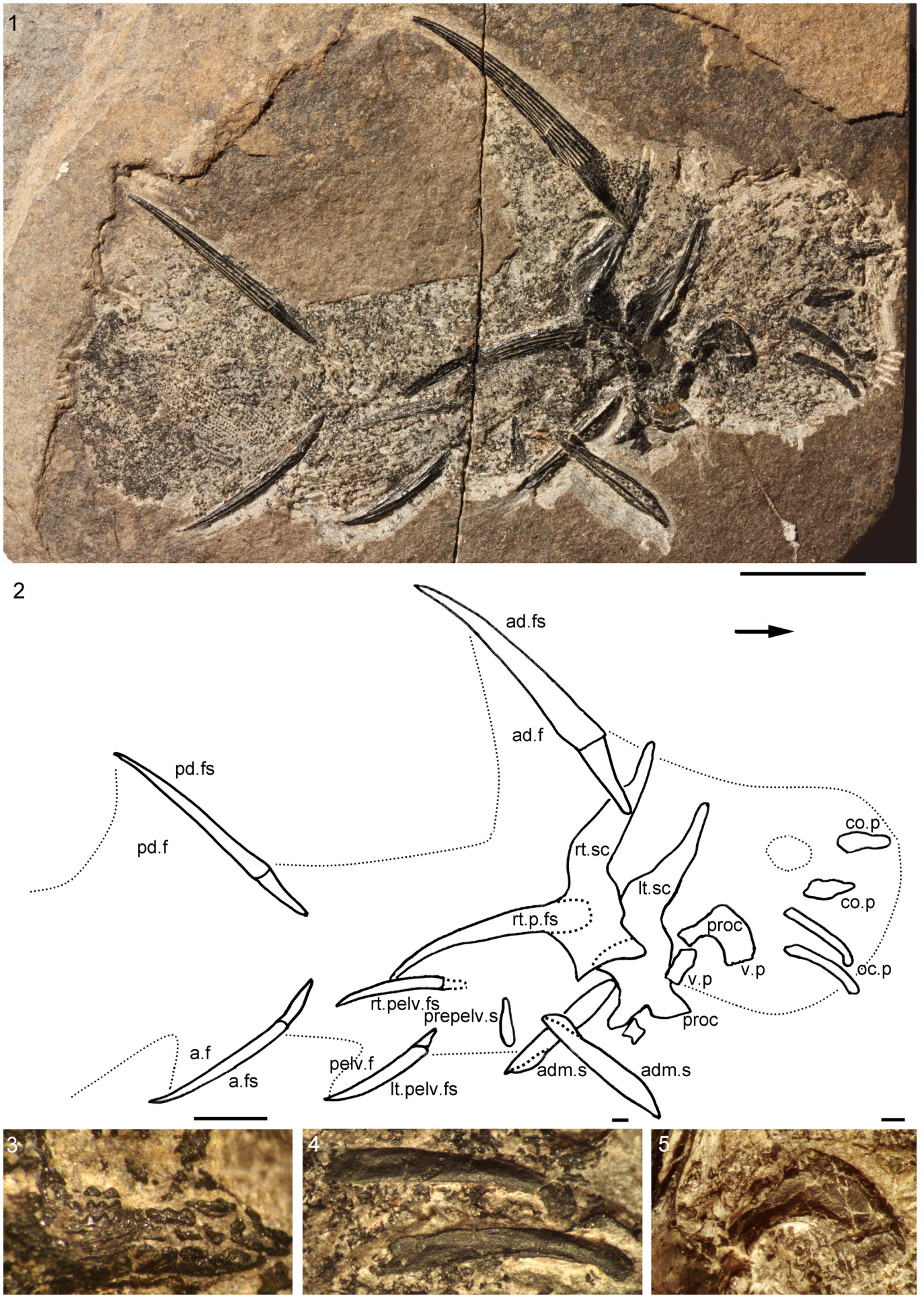

FIGURE 3. Diplacanthus crassisimuss, NMS G.2014.4.29, from Edderton, Ross and Cromarty, showing surface morphology of spines: 1 , complete specimen; 2 , line drawing identifying various elements; 3 , circumorbital bone; 4 , occlusal bones; 5 , procoracoid with ventral plate attached. Scale bars equal: $1 \mathrm{~cm}$ for 1, 2; $1 \mathrm{~mm}$ for $3-5$. Abbreviations: a.f=anal fin web; a.fs=anal fin spine; ad.f=anterior dorsal finweb; ad.fs=anterior dorsal fin spine; adm.s=admedian spine; co.p=circumorbital plate; It.sc=left scapula; It.pelv.fs=left pelvic fin spine; oc. $p=o c c l u s a l$ plate; $p d . f=p o s t e r i o r$ dorsal finweb; pd.fs-=posterior dorsal fin spine; pelv.f=pelvic finweb; prepelv.s=prepelvic spine; proc=procoracoid; rt.p.fs=right pectoral fin spine; rt.pelv.fs=right pelvic fin spine; rt.sc=right scapula; v.p=ventral plate. Arrow indicates anterior. 
1894

Diplacanthus striatus Agassiz; Traquair, $\mathrm{p}$. 254, 255.

1895 Diplacanthus striatus Agassiz; Traquair, pl. 2, fig. 1.

1902 Diplacanthus crassisimus Duff; Hay, p. 274.

1904 Diplacanthus striatus; Goodchild, p. 595.

non 1905 Diplacanthus striatus; Lambe, p. 34, 40.

1907 Diplacanthus striatus; Dean, pp. 217, 218, fig. 19.

1907 Ischnacanthus gracilis in part; Dean, p. 214, fig. 16.

non 1907 Diplacanthus striatus; Eastman, p. 10, 16.

non 1908 Diplacanthus striatus; Eastman, p. 280.

1910 Diplacanthus striatus; Smith, p. 663.

$1912 \quad$ D. striatus Ag.; Wundsch, p. 190.

non 1913 Diplacanthus striatus; Clarke, p. 115.

non 1916 Diplacanthus striatus?; Dean and Eastman, p. 622.

1929 Diplacanthus crassisimus Duff; Hay, p. 544.

1937 Diplacanthus striatus Agassiz; Watson, p. 88-95, text-figs. 14-16.

1940 Homacanthus gracilis (EICHWALD), in part: Gross, p. 21-23, figs. 1B, 2F, pl. 1.3, 1.4.

1940 Diplacanthus striatus; Gross, p. 23.

1942 Homacanthus gracilis (Eichw.), in part; Gross, p. 377, 379, 381, table 1.

1947 Diplacanthus striatus; Gross, p. 126, 127, pl. 6.3.

1954 Diplacanthus striatus Agassiz; Waterston, $p$. 11, 12.

non 1966 Diplacanthus crassisimus Duff; Gardiner, p. 50.

non 1966 "Homacanthus gracilis". Whiteaves; Gardiner, p. 52.

1966 Diplacanthus striatus Agassiz; Miles, p. 166, text-fig. 11.

1967 Diplacanthus striatus Agassiz; Novitskaya and Obruchev, p. 276, figs. 5, 14.

?1967 Homacanthus gracilis (Eichwald); Novitskaya and Obruchev, p. 278, fig. 15, pl. 1.2.

1969 Diplacanthus striatus Ag.; Heyler, fig. 29.

1971 Diplacanthus striatus; Moy-Thomas and Miles, fig. 4.13.

1973a Diplacanthus striatus Agassiz; Miles, pp. 190-194, text-figs. 39-41.

1973 Diplacanthus? carinatus Gross; in part, Gross, p. 72, 73, pl. 36.9, 36.10.

? 1973 Homacanthus gracilis (Eichwald); Gross, p. 86, figs. 13H, 14G-14M.

?1975 Homacanthus gracilis sensu Gross; Lyarskaya, p. 230.

1975 Diplacanthus striatus; Saxon, p. 15, fig. 3.

1976 Diplacanthus striatus Agassiz 1845; Paton, p. 10, 11.
1979

1979

1985

?1988a

1988b

1990

1991

1994

1994

1995

non 1995

1996

1997

1998

1998

1999

1999

1999

1999

2000

2000

2000

2001

2001

2001

2002

2003

2003
Diplacanthus crassisimus Duff; Denison, $p$. 32, figs. 4C, 19, 20, 21A-21C.

Homacanthus gracilis, in part; Denison, $p$. 52, figs. 32I, 33F.

Diplacanthus? carinatus Gross, in part; Valiukevičius, pl. 1.4, pl. 11.7, 11.8, ?pl. 13.513.8.

Diplacanthus gravis, in part; Valiukevičius, p. 77, pl. 8.1.

Diplacanthus carinatus, in part; Valiukevičius, p. 603, 604, table 2.

Diplacanthus striatus; Chaline, fig. 3.9.6.

Diplacanthus striatus Agassiz; Frickhinger, p. 242.

Diplacanthus carinatus Gross, in part; Valiukevičius, figs. 5-7.

Homacanthus gracilis (Eichwald); Valiukevičius, fig. 7.

Diplacanthus striatus; Young, p. 67, figs. 1, 7.

Diplacanthus striatus; Long, fig. on p. 94.

Diplacanthus striatus; Gagnier and Wilson, p. 151.

Diplacanthus striatus; Young, p. 47.

Homacanthus gracilis (Eichwald); Valiukevičius, p. 20, 21, 23, 26, fig. 4.

Diplacanthus carinatus Gross, 1973, in part; Valiukevičius, p. 21, 23, figs. 4, 7, 8, 12, 13, 16, 18, 19, 21.

Diplacanthus crassisimus Duff 1842; Trewin and Davidson, table 3, p. 543.

Diplacanthus striatus; Trewin and Davidson, table 3.

Diplacanthus crassisimus Duff; Dineley, fig. 6.12A-12D.

Diplacanthus striatus Duff; Dineley, fig. $6.12 \mathrm{H}$.

Diplacanthus striatus; Warren, Currie, Burrow, and Turner, p. 239.

Diplacanthus carinatus Gross, in part; Valiukevičius and Kruchek, figs. 1, 4.

Homacanthus gracilis (Eichwald); Valiukevičius and Kruchek, fig. 1.

Diplacanthus striatus; Hanke, fig. 4.4.

Diplacanthus crassisimus; Hanke, p. 310 , 311.

Diplacanthus crassissimus [sic]; Hanke, Davis, and Wilson, p. 750, 751.

Homacanthus gracilis; Valiukevičius, p. 36

Diplacanthus carinatus Gross, 1973, in part; Valiukevičius, p. 173, 197, 199, 202, tables 2, 3, fig. 20K, 20L.

Diplacanthus crassisimus Duff, 1842; Valiukevičius, p. 173. 

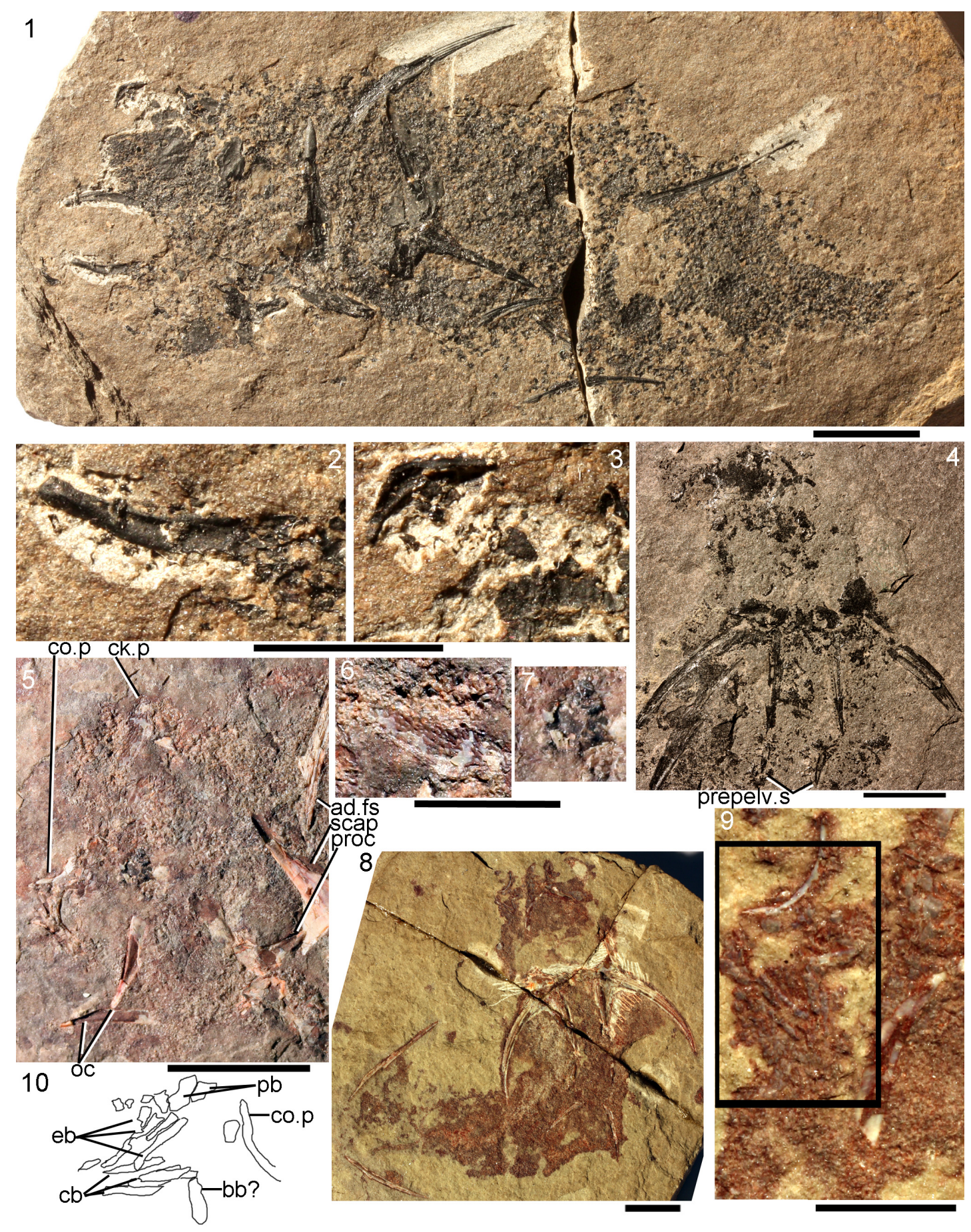

FIGURE 4. Diplacanthus crassisimus, articulated specimens: 1-3, NMS G.2014.44.3 from Edderton, Ross and Cromarty: 1, complete specimen; 2, right occlusal plate; 3, left circumorbital and postorbital plates; 4,NMS G.2014.15.21, a ventrodorsally flattened specimen from Cruaday Quarry, Orkney, showing prepelvic spines; 5-7, NMS G.1891.99.10 from Tynet Burn, Moray: 5, head region; 6, impression of a displaced cheek, rotated $90^{\circ}$ counterclockwise; 7, postorbital plate; 8-10, NHM OR.36582 from Tynet Burn, Moray: 8, complete specimen with head region ventrodorsally flattened, with articulated, displaced branchial region; 9 , branchial region; 10, sketch of branchial region elements, rotated $90^{\circ}$ clockwise. Scale bars equal: $1 \mathrm{~cm}$ for $1,5,8$ and $5 \mathrm{~mm}$ for $2-4,6,7,9$. Abbrevia-

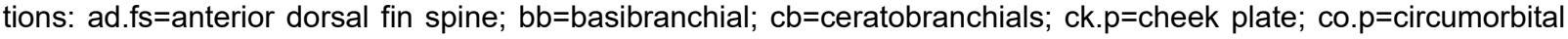
plate; eb=epibranchials; $o c=o c c l u s a l$ plate; $p b=$ pharyngobranchials; prepelv.s=prepelvic spine; proc=procoracoid; scap=scapulocoracoid. 
2005 Diplacanthus crassisimus (Duff); Newman and Dean, p. 3, 4, 5.

2005 Diplacanthus crassisimus Duff; Davidson and Trewin, fig. 3.

2006 "...Diplacanthus Striatus"; Knell and Taylor, p. 86.

2007 Diplacanthus striatus; Burrow, p. 831.

2008 Diplacanthus carinatus; Märss, Kleesment and Niit, table 1.

2010 Diplacanthus crassisimus Duff, 1842; Newman, p. 4-9, figs. 5-14

2012 Diplacanthus crassisimus; Newman, Davidson, den Blaauwen and Burrow, p. 742.

2014 Homacanthus gracilis (Eichwald); Ivanov and Märss, p. 158.

2014 Diplacanthus carinatus Gross; Ivanov and Märss, p. 158.

2014 Diplacanthus carinatus, in part; Plax and Kruchek, p. 32, 36, pl. 3.15.

? 2015 Homacanthus gracilis (Eichw.); Plax, p. 22, 31, pl. 4.9 , text-fig. 3.

? 2015 Diplacanthus carinatus Gross, in part; Plax, p. 31, text-fig. 3.

Holotype. NMS G.1891.92.333 from Tynet Burn, Moray, half a limestone nodule with an articulated fish showing the pectoral region and head exposed in ventral view, and the posterior body and tail flattened laterally.

Referred Material. Many hundreds of articulated or partially articulated specimens have been identified in public museums and private collections by the authors. The largest collections are in the NHM and NMS, all of which were examined and photographed. Specimens used in this study include the syntypes designated by Paton (1976); NMS G.1859.33.1, NMS G.1953.4.4 (part) and NMS G.1859.33.3 (counterpart) from Cromarty. Other specimens used include: from Achanarras Quarry, Caithness, NHM P.22198; from Edderton, Ross and Cromarty, NMS G.2014.4.29, NMS G.2014.15.7, NMS G.2014.44.3 and NMS G.2014.44.4; from Cruaday Quarry, Orkney, NMS G.2014.15.21 and NMS G.2014.4.30; from Sandside Bay, Caithness, NMS G.2014.44.7; from Corbie Den, Banffshire, NMS G.2014.33.9, NMS G.2014.33.10 and NMS G.2014.44.2; from East Murkle Bay, Caithness, NMS G.2014.33.11; from west of Castletown Harbour, Caithness, NMS G.2014.33.8.1-6; from Springpark, Caithness, NMS G.1878.5.349; from Tynet Burn, Moray, NMS G.1891.99.10, NHM OR.36582, NMS G.Canon Kyle no. 2 and NHM P1357a; from Gamrie, Banffshire, NMS G.1882.60.17, NMS G.1892.8.5 and NMS G.2015.11.2, NMS G.2015.11.3.
Distribution within the Orcadian Basin (Figure 2). The earliest appearance of the species in the Orcadian Basin is an isolated spine and a few scales found on the west side of Sandside Bay, Caithness in the Lybster Flagstone Formation (Figure 2.2). The species becomes much more common in the nodule localities around the Moray Firth, such as, Edderton, Gamrie, Lethen Bar, Tynet Burn, Eathie, and Cromarty. Specimens have also been collected further north in the Cadboll Point area north of Balintore. Many small specimens have been collected from Achanarras Quarry in Caithness. Disarticulated remains have been found in the Mey Formation (e.g., Murkle Bay and Castletown), but are generally quite rare above the Achanarras/Sandwick horizon. Articulated specimens were reported by Hamilton (1987) from Ness of Litter and Lythmore, but no specimens were found by the authors. Both localities have large Mesacanthus and rare Cheiracanthus specimens present and so the record is probably a case of mistaken identity. In Orkney the species is only found in the Sandwick fish bed. A fin spine impression (Figure 5.5) identified as Diplacanthus crassisimus by Mr. D. Leather (but not collected) on Westray (east side Bay of Tafts, coast before Stancro) in beds with Osteolepis panderi is the only find identified above the Sandwick fishbed.

Revised Diagnosis. Diplacanthus with maximum depth to length ratio c. 0.22-0.25; pectoral spine and posterior dorsal spine of equal length; admedian spine three-quarters the length of the pectoral spine; very short prepelvic spine positioned halfway between pelvic and pectoral spines; pelvic spine more curved than other spines, and half the length of the pectoral spine; pectoral spine with paired rows of posterior denticulations on distal half; scale crowns ornamented with transverse, serrated ridges running over a medial longitudinal ridge; orientation of transverse crown ridges changes from concave forward anteriorly to concave backwards posteriorly.

Description. Head and Branchial Region. Watson (1937) gave detailed descriptions of the head structures and sensory lines, so we will just list updated interpretations. The only large structures visible in the head region (Figures 1.1, 3.3-4, 4.2-3, 4.6-9) are the long low occlusal plates of the lower jaw (Figures 3.4, 4.2), the circumorbital bone extending about one quarter the arc of the orbit (Figures 3.3, 4.3), the ornamented cheek plate (Figure 4.6), and the smaller postorbital plate (Figure 4.7). Each cheek plate is slightly shorter than the occlusal plate and positioned just anterior to 

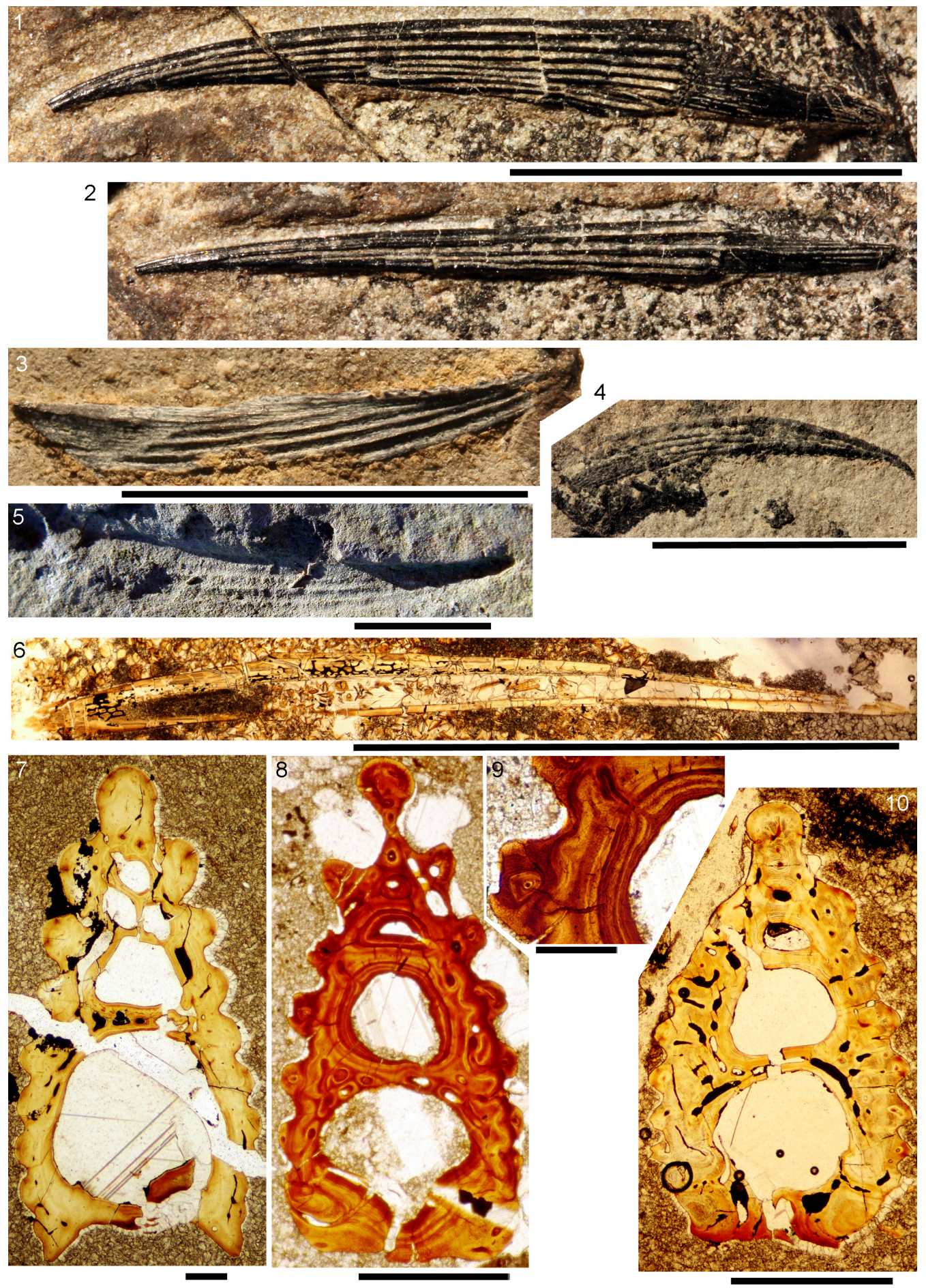

FIGURE 5. Diplacanthus crassisimus spine morphology and histology: 1, 2, NMS G.2014.4.29 from Blackpark, Ross and Cromarty; 1, anterior dorsal fin spine; 2, posterior dorsal fin spine; 3, pectoral spine of NMS G.1878.5.349 from Springpark, Caithness; 4, pectoral spine NMS G.2014.44.7 from west side of Sandside Bay, Caithness; 5, pectoral spine impression, Snaky Noust, Westray, Orkney (HY501.405); 6, longitudinal section of pelvic spine NMS G.2014.33.10 from Corbie Den, Banffshire; 7, transverse section of anterior dorsal fin spine NMS G.2014.33.9 from Corbie Den, Banffshire; 8, 9, transverse section of anterior dorsal fin spine NMS G.2014.33.11 from the south of East Murkle Bay, Caithness, with magnified image of same specimen; 10, transverse section NMS G.2014.44.2 of pectoral fin spine and bone of scapulocoracoid from Corbie Den, Banffshire. Scale bars equal $1 \mathrm{~cm}$ for $1-6(1,2$ at same scale); $1 \mathrm{~mm}$ for 8,$10 ; 0.1 \mathrm{~mm}$ for 7,9 . 
the shoulder girdle complex. As noted by Watson (1937, p. 88, 90, plate 10.1), branchial arches, jaws and other endoskeletal elements are only preserved in rare specimens from Tynet Burn. We have recognized one specimen, NHM OR.36582 (Figure 4.8-10), which shows at least four of the branchial arches displaced but articulated. The branchial region is very short, less than the arc of the longest circumorbital bone. Elements identified as pharyngobranchials, epibranchials, ceratobranchials and possibly a basibranchial are distinguished; the epibranchials and ceratobranchials form a V-shape, and the pharyngobranchials are more or less aligned with the epibranchials (Figure 4.10). Jaw cartilages and the hyoid arch do not appear to have been mineralized in this specimen.

Morphology of the Spines. All the spines, except the admedian and prepelvic spines, are laterally compressed, with smooth longitudinal ridges on each side and a leading edge ridge that is only slightly wider than the other ridges (Figures 3.1-2, $4.1,5.1-4,6,7.1-4)$. The dorsal, anal, and pectoral spines are long and slender. The pectoral spine is also slender, but is highest relative to length. The dorsal and anal fin spines are deeply inserted. The inserted parts, about one fifth of the total length, lack ornament ridges but show the thin closeset parallel ribbing diagnostic of diplacanthiforms. In cross section, the spines (other than the admedian and prepelvics) are markedly higher than wide (Figures 5.7-8, 5.10, 6), whereas the admedian and prepelvic spines are much broader, with their width mostly exceeding the height. Below the groove separating off the leading edge ridge, the sides of the spines are slightly convex, with the lateral ridges aligned parallel to the leading edge ridge and separated by concave-based narrower grooves c. $0.2-0.35 \mathrm{~mm}$ wide. In mature fish, the posterior lateral ridges sometimes bear tiny, sharply crested, secondary ribs, which resemble the micro-ornament on the scale crowns. These secondary ribs run parallel with the crest and sides of the lateral ridge. Larger spines have more lateral ridges than smaller spines: the anterior dorsal fin spine has up to nine per side, the smaller posterior dorsal spine has up to six. Anal and pelvic spines are straight and closely resemble each other, having three or four ridges per side; pelvic spines differ from anal spines mainly in the lack of a long insertion. The robust, sickle-shaped pectoral spine has up to 10 lateral ridges per side in mature specimens and is always more or less asymmetrical in cross section. The lower surface is slightly flatter and extends further posteriorly than the more con- vex, dorsally facing side. The distal half of the spine has paired rows of small, recurved denticles c. $0.2 \mathrm{~mm}$ apart on either side of the posterior median axis (Figure 5.3, 5.7). On all fin spines, this posterior face has an open pulp canal proximally, extending the full length of the inserted parts in the dorsal and anal spines (Figure 6). In the exserted parts of these and other spines, the open canal is closed over and continues distally as the main central canal. The relatively large admedian spines, which are about three-quarters the length of the pectoral spines, and the smaller prepelvic spines (about a quarter the length of the pectorals) differ in being broad and flat proximally, with a height/ width ratio from 0.5 to 0.8 , thinning to equal width and height distally. On these spines, the parallel, longitudinal ridges all have sharp crests, and are separated from each other by broad, concave grooves (Figures 6, 7). The lateral ridges, just one to three on each side, bear tiny secondary ribs parallel to the crest of the ridge. The spines have a broad open pulp canal proximally, but the canal only extends to about halfway along the spine. The prepelvic spines, which lack an insertion area, were directly intercalated between normal body scale rows, and point in a posterior, slightly ventral direction. The admedian spines abut normal body scales along their medial sides, but articulate with the posterior pinnal plate laterally. This pinnal plate articulates laterally with the base of the pectoral spine. The admedian spines point in a posterior direction, slightly ventrally.

Histology of the Spines. Transverse sections (Figures 5.7-10,6) show that spines of Diplacanthus crassisimus have one to five successively smaller accessory pulp canals above the main pulp canal, with randomly distributed, narrow calibre canals interconnecting all pulp canals and small vascular canals penetrating the trabecular dentine forming the sides of the spines. Vascular canals run longitudinally through the trabecular dentine, branching towards the spine tip. In the exserted parts of the spines, each ornament ridge always contains at least one canal running longitudinally below the crest and branching distally (Figure 5.9). Pore canals branch off these canals and open out in the grooves between the ridges. The canals under the ornament extend as open grooves over the inserted parts of the median spines, forming the regularly spaced longitudinal striations. Denteons round the canals are thickest towards the distal, oldest parts of the spines, and less well developed around the pulp canals, which show some infilling by lamellar layers (Figure 5.8), a dis- 


\section{2}

2 ad.fs

?

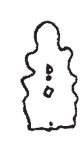

$\left\{\begin{array}{l}\{0 \\ 0\}\end{array}\right.$

$\left\{\begin{array}{l}0 \\ 0\end{array}\right\}$

$\left\{\begin{array}{l}0, \\ 0 \\ 0\end{array}\right\}$

$\{0,0$
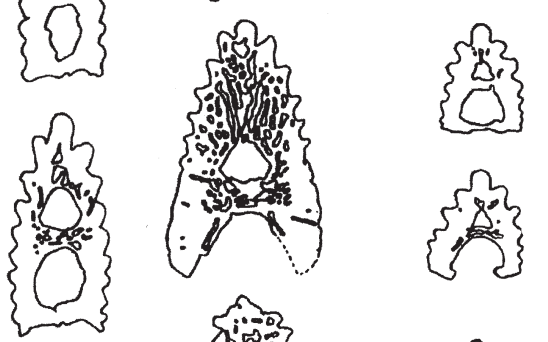

-
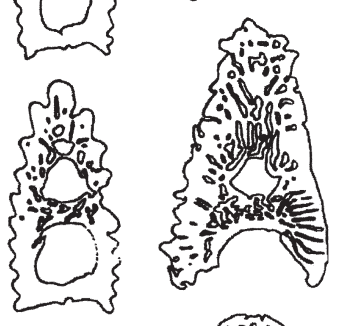

\{.:
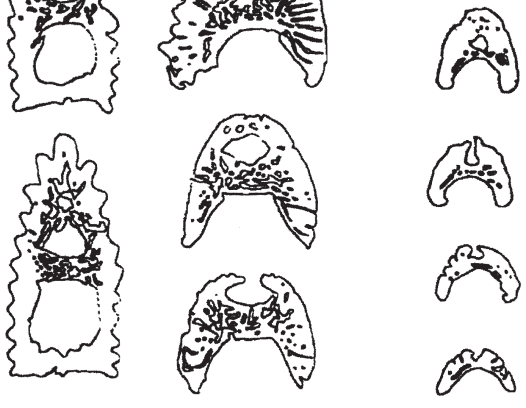

3 a.fs

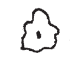

$\{3$
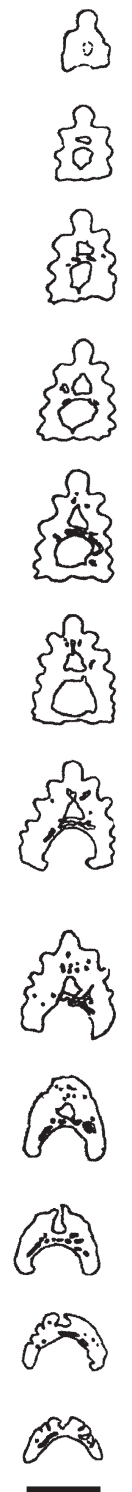

4 pelv.fs
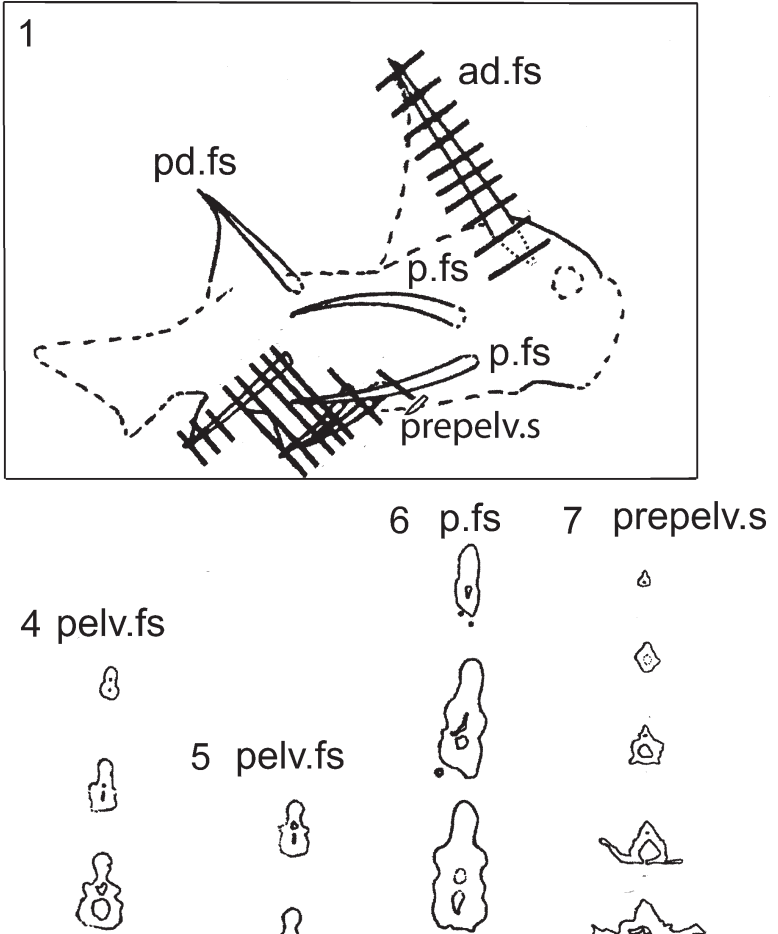<smiles></smiles>

री<smiles>[c-]1ccc[se]1</smiles>

$\{0\}$
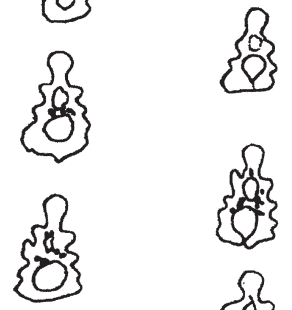

$\left\{\begin{array}{l}\Omega \\ \{\end{array}\right.$
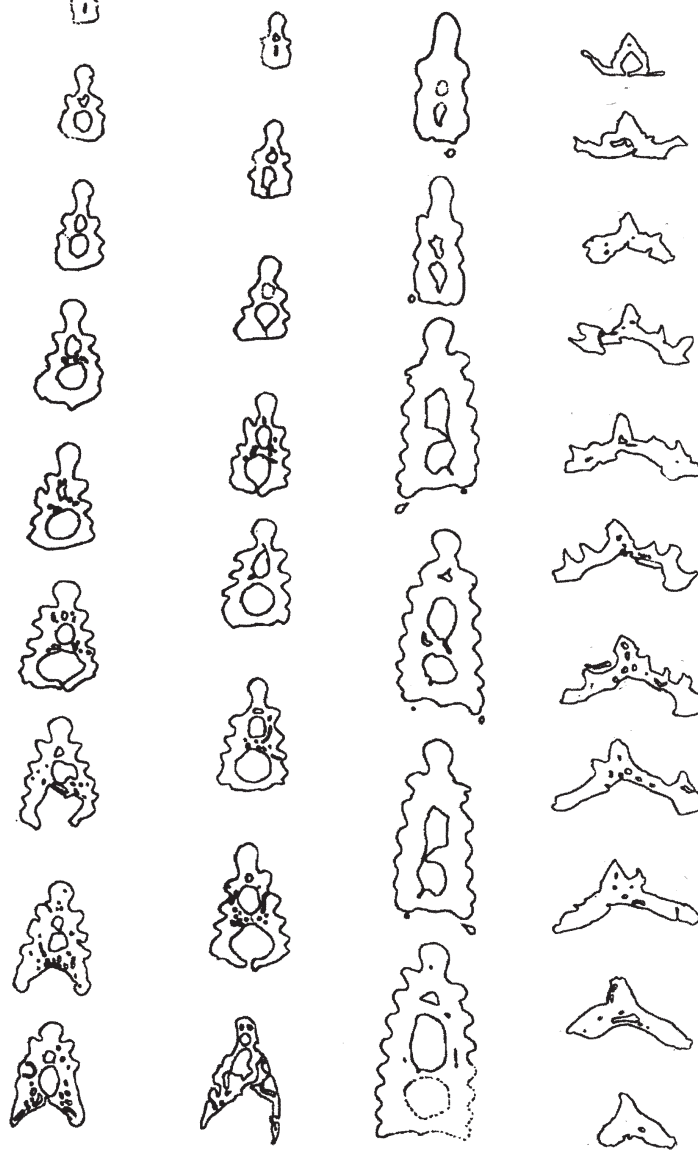<smiles>[C-]1C=C1</smiles>

$\left\{\begin{array}{l}n \\ 0 \\ 0\end{array}\right\}$<smiles>CCOC</smiles><smiles>C1CC2CC3CC1CC(C2)C3</smiles><smiles>[C]1CC2CCC(C1)C2</smiles><smiles>O=S(=O)(O)OC12CC3CC(CC(C3)C1)C2</smiles><smiles>[C]1CCCC1</smiles>
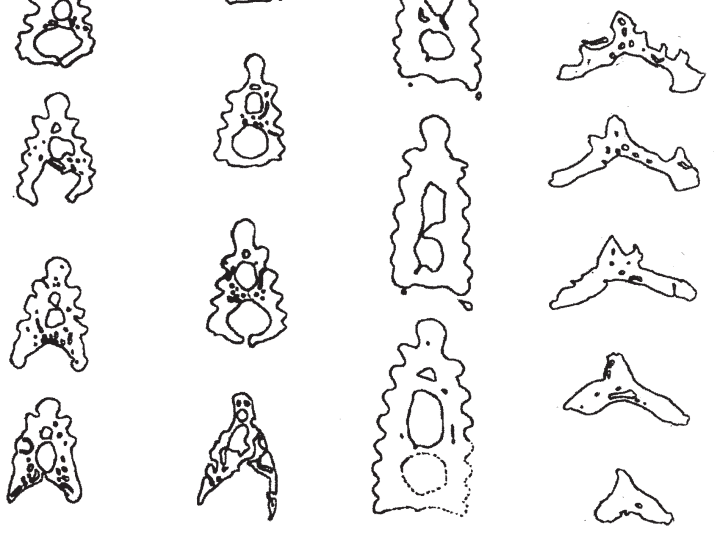

FIGURE 6. Drawings of serial transverse sections of the spines of Diplacanthus crassisimus. 1, sketch of NMS G.2014.15.7, from Edderton, Ross and Cromarty, showing the position of sections in 2-6; the sections run from the distal end to the base of each spine. 2, anterior dorsal fin spine (ad.fs); 3 , anal fin spine (a.fs); 4, right pelvic fin spine (pelv.fs); 5 , left pelvic fin spine; 6 , left pectoral fin spine (p.fs). 7 , Sollas sections of a prepelvic spine (prepelv.s) on NMS G.2014.44.4. Scale bars equal $1 \mathrm{~mm}$. 
tinctive character found only in $D$. crassisimus amongst the Scottish Middle Devonian acanthodians. The admedian and prepelvic spines sometimes have small accessory pulp canals. All spines have an outer layer of orthodentine on the crests of the leading edge and lateral ridges, a thick middle layer of trabecular dentine, and a dense laminar tissue lining the main and accessory pulp canals. In the orthodentine, the tubules are widely spaced and relatively short, between about 10 and $50 \mu \mathrm{m}$ long, and branching near the surface. The inner layer lacks bone cells and dentine tubules, and is thus difficult to distinguish as either a laminar bone or atubular dentine layer.

Shoulder Girdle Complex. (Figures 7, 8, 9) Determining the layout of this structure is best interpreted by examination of isolated complexes (Figure 7.5-6). The endoskeletal plus dermal bone elements almost completely encircled the body (Figure 7.7), reminiscent of the thoracic armour in placoderms. On the scapulocoracoid, the postbranchial flange is only developed close to the base of the cylindrical shaft, and the L- or wide Vshaped procoracoid appears to have abutted the anterior edge of the scapulocoracoid. Lack of the procoracoid on isolated complexes and only rare preservation in situ on articulated specimens (e.g., Figure 7.7, and Figure 3.5 for displaced procoracoid) indicate that the procoracoid was not fused to the scapulocoracoid. The posterior flange of the scapula reaches almost to the dorsal tip of the shaft, expanding in length ventrally towards the coracoid, which angles inwards (Figure 7.7). No differentiation is visible between the internal bone surface of the scapula and the coracoid, with the latter extending back under the base of the admedian spine. The dermal armour comprises a pinnal plate articulating with or fused to the scapulocoracoid and the admedian spine, and a ventral plate fused to the base of the procoracoid towards its medial end, so that the ventral plates of each side are almost touching. The base of the pectoral fin spine is rigidly constricted or fused into the dermal and endoskeletal structures, clearly shown in serial sections of the shoulder girdle complex (Figures 8.1-2, 9). Our reconstructions (Figure 10) show lateral and ventral views of the complexes.

Morphology of the Scales. (Figure 11) As originally described by Gross (1947), the scales have delicate ribs arranged in semicircles with the open side in an anterior direction, at least in the anterior part of the crown. More posteriorly the delicate ribs become almost straight in a transverse direction and, without interruption, cross over a broad cen- tral ridge. The scale base is oval in outline and wider than long (Figure 11.8-11, 11.13-15). The base is positioned below the anterior half of the crown (Figure 11.9-15), with the relatively thin, posterior half of the crown extending far behind the base. The neck is moderately constricted on all sides and is also oval in cross section, but with the lateral ends of the oval often sharply pointed. Along the anterior and lateral sides, small vertical buttresses rise from the middle of the neck and support the underside of the crown. Relatively large scales near the lateral line have their crown surface nearly parallel with the base. In smaller scales such as those from the tail region, the surface of the crown is inclined strongly antero-posteriorly. The surface of the crown is more or less rhombic in shape with rounded anterior and lateral corners. The posterior corner is more sharply pointed, and the latero-posterior edges are denticulated (Figure 11.14). Midflank in the posterior parts of the body, scale length is about equal to the width. In more anterior parts of the body, width of midflank scales usually exceeds the length. All scales have a broad central ridge, extending the length of the crown surface, gradually diminishing in height and width posteriorly and reaching almost to the posterior corner (Figure 11.7-9, 11.13-15). A relatively deep pit is sometimes present in front of the central ridge, almost immediately behind the anterior corner. Surrounding this pit, the crown surface is slightly concave, but in the central and posterior parts the crown surface is almost flat or slightly convex. Thin, sharply crested transverse ridges perpendicular to the broad central ridge cover the whole surface of the crown (Figure 11.2-9, 11.1215). These tiny ridges, $10-20 \mu \mathrm{m}$ apart and $15-20$ $\mu \mathrm{m}$ high in the anterior half, cross the broad central ridge without interruption; they are arranged in a Uor horseshoe-shape with the concave side facing anteriorly. The ridges become straighter more posteriorly. These ridges are mostly inclined anteroposteriorly, although ridges on crowns with the anterior pit can be inclined anteriorly or towards the pit. The crests of the ridges are serrated, with the sharp denticulations c. $10 \mu \mathrm{m}$ apart.

Histology of the Scales. (Figure 12.1-3) Scales of Diplacanthus crassisimus have only a few crown growth zones, with a maximum of five or six in the largest scales. Ascending canals rise up to the anterior crown from slit-like openings in the middle of the neck, widening and uniting into a canal c. $10-15 \mu \mathrm{m}$ in diameter running parallel to the anterior rim (Figure 12.3). Each growth zone has only one system of ascending canals and one canal 

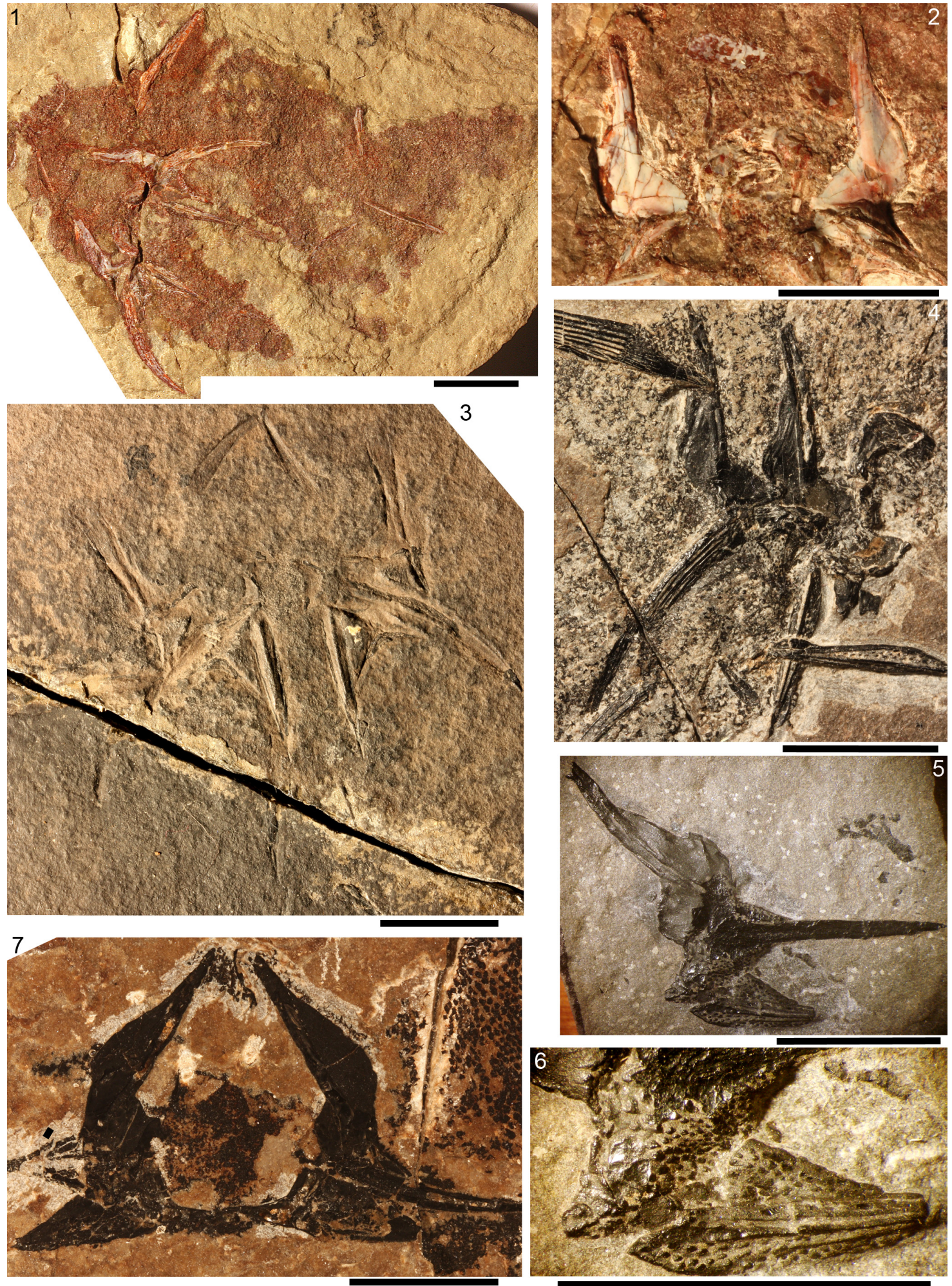

FIGURE 7. Diplacanthus crassisimus shoulder girdles. 1, NMS G.Canon Kyle no. 2 from Tynet Burn, Moray, showing ventral view of the shoulder girdle complexes; 2, NHM P.1357a from Tynet Burn, Moray, pectoral girdle region; 3, NHM P.22198 from Achanarras Quarry, Caithness, complete specimen; 4, NMS G.2014.44.3 from the Edderton, Ross and Cromarty; 5, 6, left shoulder girdle complex of NMS G.2014.4.30 from Cruaday Quarry, Orkney; 7, NMS G.2014.44.4 from the Edderton, Ross and Cromarty, natural transverse section through articulated uncompressed shoulder girdle region (prepelvic spines subsequently Sollas sectioned). Scale bars equal $1 \mathrm{~cm}$. 
parallel to the anterior rim and corners, with smaller canals, each c. $5 \mu \mathrm{m}$ diameter, branching back sharply and slightly downward into the slightly concave anterior part of the crown table. These canals follow the bottom of the grooves between the narrow ridges on the surface (Figure 12.1-3, 12.8). Extremely thin dentine tubules parallel the smaller canals and then turn upwards in the direction of the serrated crest of the thin transverse ridges (Figure 12.6). New crown growth zones completely superpose older zones; they are thin anteriorly and wider laterally and posteriorly, with the lateral and posterior areas extending out beyond the base and neck. In the primordial growth zone, there are no canals running under the grooves between the ridges; these canals develop only with the next growth zone and are then enclosed by dentinal tissue. Only the canal system of the youngest growth zone is still open. The crests of the tiny ribs are slightly more translucent than the rest of the scales, indicating they are formed only of durodentine (Figure 12.2, 12.7).

The base of larger scales shows four or five sets of cross-layered (laminated) bone layers. The low apex of the base cone is posterior to the low point of the scale crown. The primordial growth zone has a hollow, concave base but with successive growth zones the base becomes slightly convex. Growth lines in the base are continuous with growth zones in the neck and crown (Figure 12.10). Sharpey's fibres in the base are poorly developed or absent, and canals of Williamson are rare.

Remarks. Past workers regarded the long thin plates in the mouth region as mandibular bones supporting the lower jaw cartilages, but these have been reinterpreted as occlusal plates on the lower jaws (Newman et al., 2012). The cheek plate probably functioned as an operculum for the branchial region, given its position extending between the mouth and the shoulder girdle. The V-shaped layout of elements in the branchial region is comparable with that observed in the Permian acanthodid Acanthodes (Miles, 1973b) and recently in the Carboniferous shark Ozarcus mapesae Pradel et al., 2014, deemed by the latter authors to represent the ancestral gnathostome condition (Pradel et al., 2014, figure 3).

Middle Devonian isolated spines which Agassiz (1844-45) assigned to Homacanthus gracilis (Eichwald), 1844 (synonym: Homacanthus arcuatus Agassiz, 1845) are identical to pectoral spines of Diplacanthus crassisimus. The spines are curved, laterally compressed, and have a promi- nent ridge along the leading edge, a few smooth longitudinal ribs on the flanks, and a double row of recurved denticles along the distal half of the posterior face of the spines (Denison, 1979, figure 22I). Other spines from the Baltic with posterior denticles extending the length of the exserted part of the spine, which have previously been assigned to $H$. gracilis, are pectoral spines of $D$. tenuistriatus. Gross (1973) described the histology of the double row of recurved denticles in juvenile spines from erratic blocks in the Middle Devonian Baltic region, and his description accords with our observations on the histology of the recurved denticles in the pectoral spine of $D$. crassisimus (as well as $D$. tenuistriatus). Spines assigned to $H$. gracilis are also recorded from the Narova, Aruküla, and Burtnieki beds (Eifelian-Givetian) in the Baltic (Lyarskaya, 1975; Denison, 1979; Valiukevičius, 1998, table on p. 7) and Stolin beds (middle Givetian) in Belarus (Plax, 2015).

Watson (1937, figure 16) and Miles (1973a, text-figure 39) both described and illustrated the arrangement of elements forming the shoulder girdle, but neither of their reconstructions is totally accurate. Interpretation of the structure has been hampered by the ventrodorsal (Figure 7.1-3) or lateral (Figure 7.4) flattening of the components, and is best interpreted by examination of isolated complexes (Figure 7.5, 7.6).

As originally described by Gross (1947), the scales of Diplacanthus crassisimus ( $D$. striatus) differ markedly from most other acanthodian scales, particularly in their crown ornament (Figure 11.2-9, 11.12-15). Gross (1947, p. 126) mentioned that the crown does not have the typical acanthodian sculpture of radial ribs, but instead possesses delicate ribs ("feine Leisten"), arranged in semicircles with the open side in an anterior direction, at least in the anterior part of the crown. Comparison of the original description and figured specimens of Diplacanthus? carinatus Gross (1973, p.73, plate 36.8-10) a species based on scales from erratic blocks in northern Germany transported from the Eifelian Narova Beds of the Baltic region - with the scales of $D$. crassisimus, indicates that $D$.? carinatus is also a synonym of $D$. crassisimus. Valiukevičius $(1985,2003)$ assigned scales from the Baltic Narva Regional Stage and the Eifelian? Vstrechnaya Formation, Severnaya Zemlya to $D$. carinatus. Plax and Kruchek (2014) and Plax (2015) assigned scales from the Givetian Goryn, Stolin and Moroch beds in Belarus to $D$. carinatus. Based on morphological and histological similarities and contemporaneous occurrences, Homacanthus gracilis, D. 


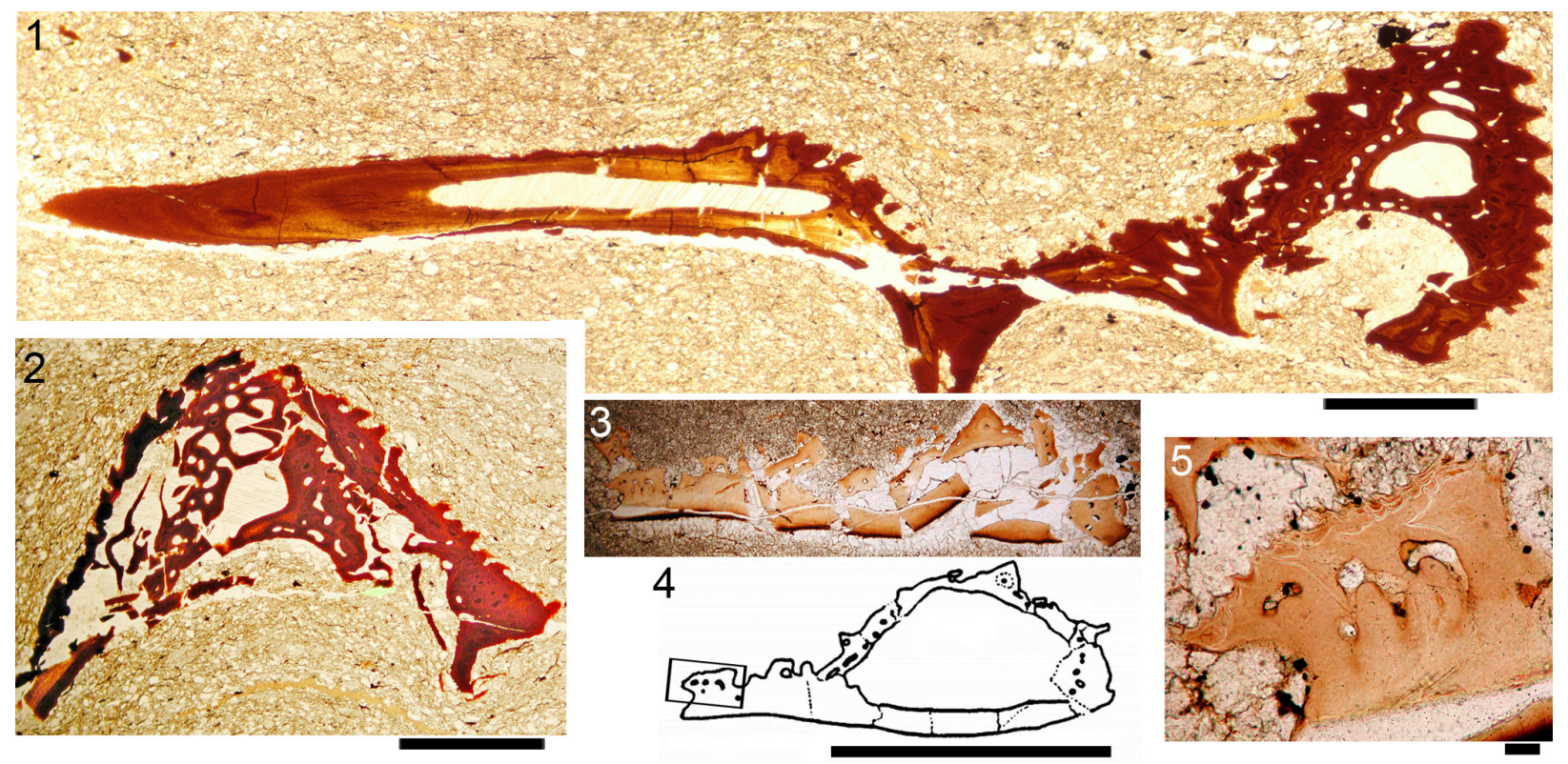

FIGURE 8. Diplacanthus crassisimus shoulder girdle thin section images. 1, 2, NMS G.2014.33.8 from west of Castletown Harbour, Caithness: 1, section through pectoral spine, pinnal plate, ?procoracoid, and scapulocoracoid; 2, transverse section through base of pectoral fin spine enclosed by pinnal plate and remnants of the endoskeletal coracoid plate; 3-5, section through admedian spine NMS G.2015.11.2 from Gamrie, Banffshire: 3, proximal end of admedian spine, inner bone base layer is the coracoid; 4, line drawing of reconstructed section; 5 , scale-like ornament towards edge of admedian spine (area box in 4). Scale bars equal $1 \mathrm{~mm}$ in 1, 2, 4; $0.1 \mathrm{~mm}$ in 5 .

carinatus (in part), and D.? carinatus (in part) are here all considered junior synonyms of $D$. crassisimus.

Diplacanthus kleesmentae Valiukevičius, 1986 (in Valiukevičius and Karatajūtè-Talimaa, 1986), based on rather poorly preserved scales from the late Emsian to early Eifelian of the Baltic region, is also similar to $D$. crassisimus, with numerous delicate ribs arranged in horseshoeshape around a deep pit near the anterior edge of the scale. However, D. kleesmentae scales have only a low broad, central ridge, and the delicate transverse ridges are not present in the lateral and posterior areas of the crown; also, the crown is formed of up to 10 growth zones. Another scalebased taxon Diplacanthus gravis Valiukevičius, 1988a from the Eifelian-Givetian Aruküla Regional Stage in the Baltic differs from the Scottish species in having a convex base that is almost pointed at its deepest, and the crown normally has two paired, branching ridges medially running the length of the crown. Diplacanthus poltnigi Valiukevičius, 2003 from the Lochkovian of Severnaya Zemlya and the Canadian Arctic differs in having subparallel grooves extending the length of the crown, or converging near the posterior corner.
This species should probably be reassigned to Uraniacanthus based on the crown ornament. Diplacanthus horridus Woodward, 1892 and D. ellsi Gagnier, 1996 from the Frasnian Miguasha Formation, Quebec, differ in having scales with subparallel ridges, comparable to the ornament on scales of Rhadinacanthus longispinus.

Diplacanthus tenuistriatus Traquair, 1894

Figure 1.3-44, Figure 13, Figure 14, Figure 15, Figure 16, Figure 17, Figure 18, Figure 19, Figure 20, Figure 21, Figure 22, Figure 23

1892 Homacanthus borealis Traquair; Traquair, p. 205, pl. 8.

1895 Diplacanthus tenuistriatus; Traquair, p. 244.

1900 Diplacanthus tenuistriatus; Wandolleck, p. 360, 365.

1904 D. tenuistriatus; Goodchild, p. 595.

1907 Diplacanthus tenuistriatus; Dean, p. 216, 222.

1923 Diplacanthus tenuistriatus; MacFarlane, p. 303.

1937 Diplacanthus tenuistriatus; Westoll, p. 22.

1940 Homacanthus gracilis (EICHW.), in part; Gross, p. 21, pl. 1, 2.

1954 Diplacanthus tenuistriatus Agassiz; Waterston, p. 12. 


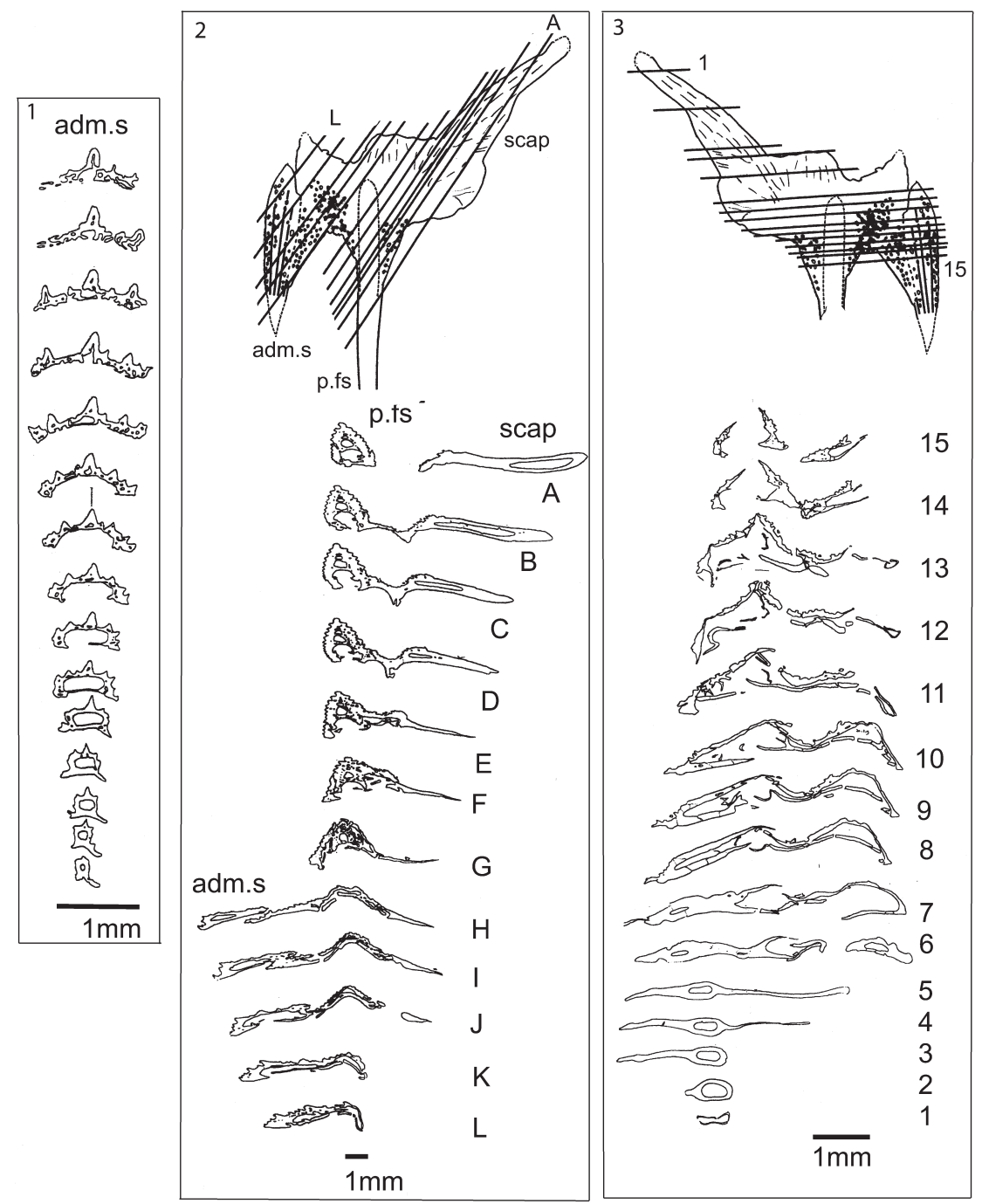

FIGURE 9. Line drawings of serial transverse sections through pectoral girdle elements of Diplacanthus crassisimus; sketch of whole specimen NMS G.2014.4.30 used to denote position of the sections shown in 2, 3 (mirror image sketch in latter). 1, serial destructive Sollas sections through admedian spine from west of Castletown, Caithness. 2, thin sections A-L through an isolated pectoral girdle complex NMS G.2014.33.8, from west of Castletown harbour. 3, Sollas sections 1-15 through an isolated juvenile pectoral girdle complex (without pectoral spine) from west of Castletown, Caithness. Abbreviations: adm.s=admedian spine; $p . f s=p e c t o r a l$ fin spine; scap=scapula.

? 1973 Homacanthus gracilis, in part; Gross, p. 86.

1973 Diplacanthus? carinatus Gross, in part; 1999 Gross, p. 72-73, pl. 36.8.

1976 Diplacanthus tenuistriatus Traquair; Paton, p. 11-12.

1979 Diplacanthus tenuistriatus Traquair; Denison, p. 32.

1979 Homacanthus gracilis, in part; Denison, fig. 32J.

1985
Diplacanthus? carinatus Gross, in part; Valiukevičius, pl. 1.3, 1.5, pl. 3.1, 2, pl. 11.9
D. tenuistriatus; Young, p. 48.

D. tenuistriatus Traquair, 1894; Dineley, p. 3. akantoodi somused; Kleesment, Nestor, and Soesoo, p. 4 top figure.

2001 D. tenuistriatus; Hanke, Davis, and Wilson, p. 751.

2005 Diplacanthus tenuistriatus (Traquair); Newman and Dean, p. 3, 4, 5 .

2010 Diplacanthus tenuistriatus Traquair, 1894; Newman, p. 12, 13, figs. 18, 19, 20. 

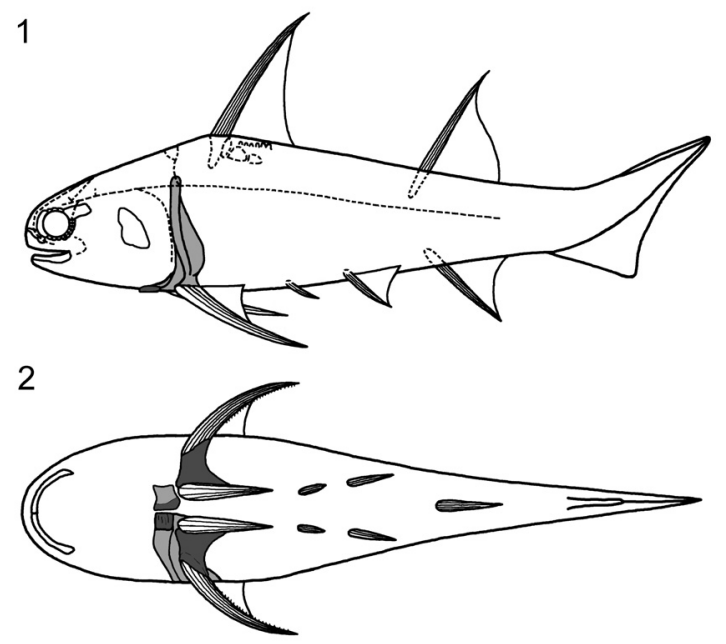

FIGURE 10. Reconstruction of the pectoral girdle of Diplacanthus crassisimus. 1, lateral view. 2, ventral view showing Miles' (1973a) interpretation on the left hand side of the fish and the authors' revised version on the right hand side of the fish. Dark grey fill indicates dermal elements, light grey fill indicates endoskeletal elements.

Type Material. Syntypes NMS G.1859.33.90 (counterpart NMS G.1859.33.91) from Cromarty, Moray, NMS G.1892.8.6 (counterpart NMS G.1892.8.7) from Gamrie, Banff and NMS G.1891.92.340 (Figure 1.4) from Gamrie, Banff.

Referred Material. The following are all the known articulated specimens: from Achanarras Quarry, Caithness, NMS G. 1897.55.1 (part), NMS G. 1897.55.2 (counterpart) and NHM P.22198; from Tynet Burn, Moray, NMS G. 1870.14.144 and NMS G.Canon Kyle no. 1; from Gamrie, Banffshire NMS G.1892.8.8 (part) and NMS G.1892.8.9 (counterpart). Disarticulated remains consisting of spines and pectoral girdle complexes include: from Marwick Bay, Orkney, QM F58024, NMS G.2014.4.18, NMS G.2014.4.20, NMS G.2014.4.23, NMS G.2014.7.35, NMS G.2014.7.36, NMS G.2014.15.21, NMS G.2014.15.22, NMS G.2014.20.20, NMS G.2014.44.5; from Appat Hill, Caithness, NMS G.1901.153.1; from Birsay, Orkney, NMS G.1898.163.2; from North Ronaldsay, Orkney, NMS G.2014.33.1; from Flashes, Hoy, Orkney, NMS G.2014.4.27.

Distribution within the Orcadian Basin (Figure 2). Diplacanthus tenuistriatus is the rarest of the diplacanthid species. It is found in some of the Moray Firth nodule beds including Gamrie, Cromarty, and Tynet Burn. One articulated specimen NMS.G1879.55.1, 2 is known from Achanarras Quarry. From Caithness there are also three isolated spines NMS G1892.91.1 from Lybster (holotype of Homacanthus borealis, Figure 1.3), NMS G 1901.153.1 from Appat Hill (Figure 14.5), NMS.G.1965.36 from Taldale Quarry, as well as a pectoral girdle complex NMS G.1898.152 from Brims Ness. In Orkney the species is also rare and mostly represented by isolated spines found with the placoderm Dickosteus threiplandi (Miles and Westoll, 1963) in deposits of the Upper Stromness Flagstone Formation. The species has not been found in the Sandwick fish bed. Recently a spine (NMS.G.2014.33.1, Figure 16.7) was collected on the island of North Ronaldsay in the Middle Rousay Formation, occurring with the placoderm Millerosteus minor (Miller, 1858).

Revised Diagnosis. Diplacanthus with spines ornamented with finely striated, closeset longitudinal ridges; pectoral spines have five to nine ridges per side, and paired rows of denticles along the whole length of the exserted portion of the spine, with larger denticles distally and smaller close set denticles proximally; admedian spines about a third the length of the pectoral spines; prepelvic spines slightly shorter than pelvic spines; median spines with long insertion, about a quarter to a third the total length of the spine; anal spine shows moderate curvature; grooves between spine ridges subcircular or flask-shaped in cross-section; one circumorbital plate round the anterodorsal quarter of the orbit; scale crowns with U- or V-shaped straight or sinuous ridges fanning out from the posteromedian ridge and often bifurcating towards the lateral edges; scale crowns are formed of mesodentine, lacking wide radial and ascending canals other than a few canals opening low in the neck.

Description. Head Region. (Figure 13.4) Diplacanthus tenuistriatus closely resembles $D$. crassisimus, differing in the characters noted in the diagnosis. A few specimens have poorly preserved elements on the head. The one large circumorbital plate is anterodorsally positioned and about a quarter the circumference of the orbit. The occlusal plates are slender and about the length of the orbit. Cheek plates appear to be shorter than the occlusal plates.

Morphology of the Spines. (Figures 13, 14, 15) Most distinguishing characters for Diplacanthus tennuistriatus are spine features. Compared with spines of $D$. crassisimus in $D$. tenuistriatus the furrows between longitudinal ridges on the sides are are much narrower (Figures 14, 15) and the flattened surfaces of the ribs exhibit a delicate striation (Figure 15.4). 

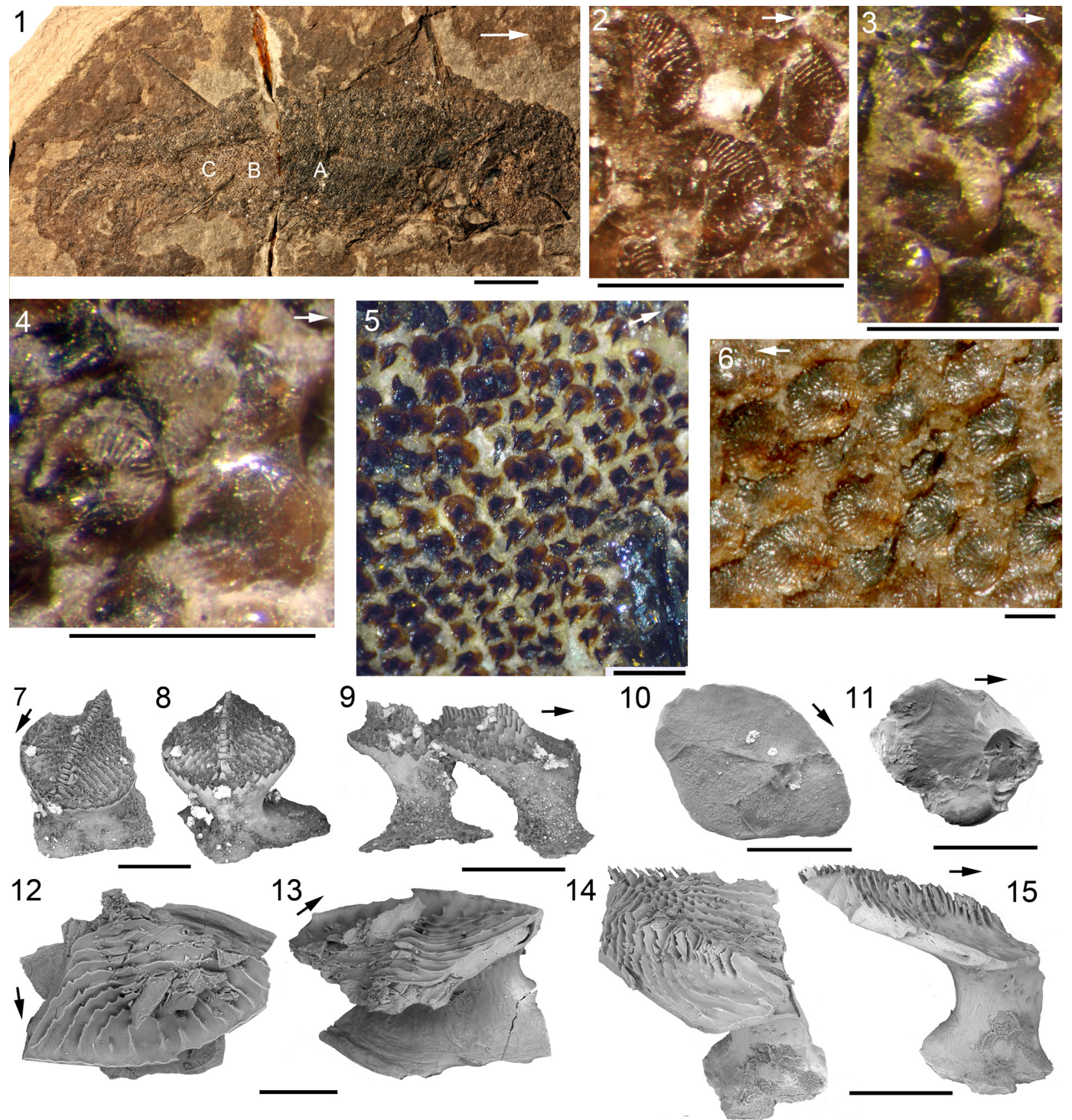

FIGURE 11. Diplacanthus crassisimus from Gamrie, Banffshire, squamation. 1-5, NMS G.1882.60.17, articulated specimen showing scale morphologies: 1 , the complete specimen, with $\mathrm{A}-\mathrm{C}$ denoting areas of squamation shown in Figure parts 2-5: 2, 3, area A; 4, area B; 5, area C. 6, NMS G.1892.8.5, mid-body squamation. 7-11, scales slide NMS G.1882.60.17.1, Scanning Electron Micrographs (SEMs): 7, 8, crown and anterior views; 9, lateral view of scale pair; 10, basal view; 11, undersurface of crown (neck and base broken off). 12-15, scales slide NMS G.2015.11.3.1, SEMs: 12, 13, crown and posterior views; 14, 15, laterocrown and lateral views. Scale bars equal $1 \mathrm{~cm}$ for $1 ; 1 \mathrm{~mm}$ for $2-5 ; 0.2 \mathrm{~mm}$ for $6-11,14,15 ; 0.1 \mathrm{~mm}$ for 12,13 . Arrows directed anteriorly. 

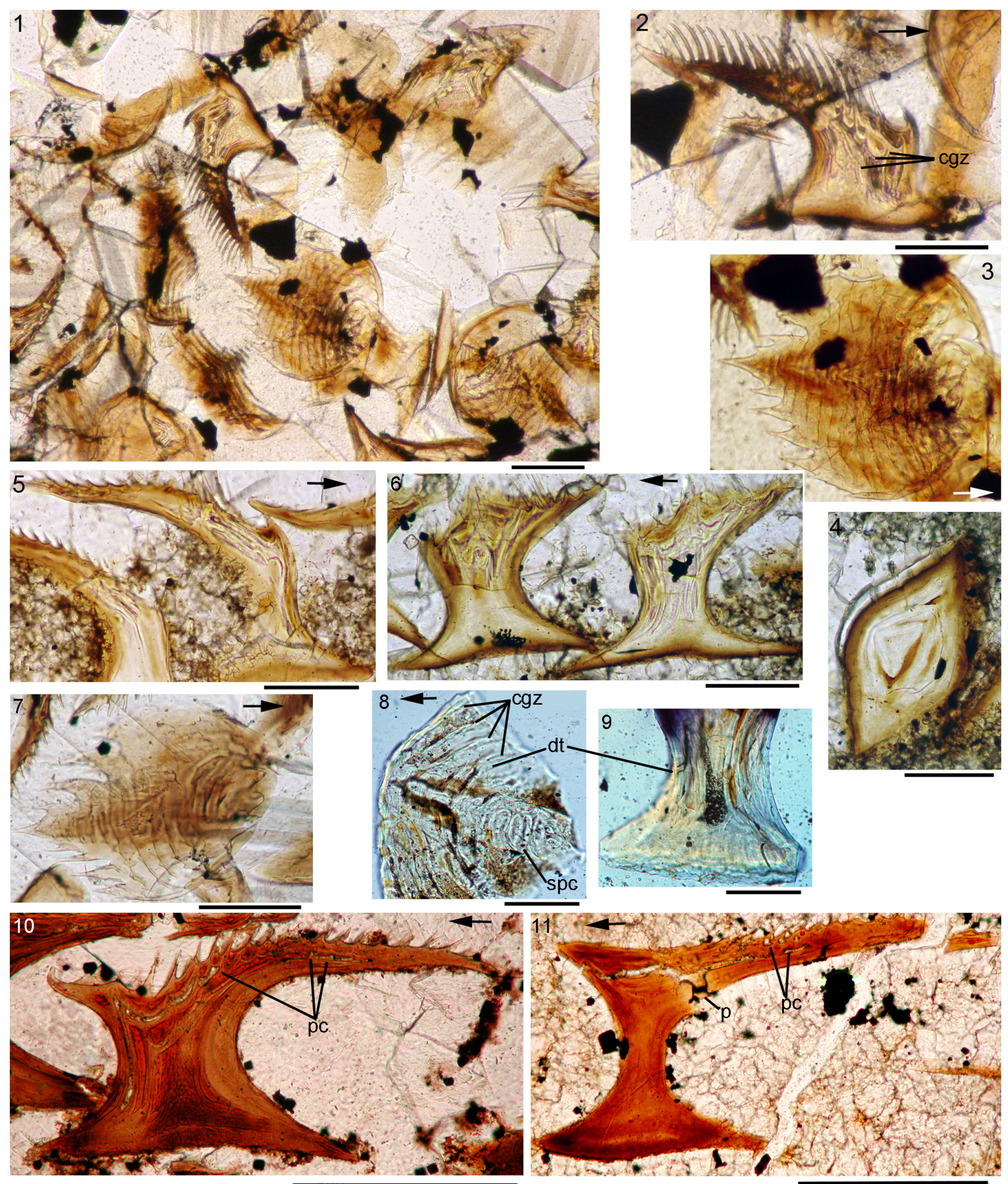

FIGURE 12. Diplacanthus crassisimus scale histology. 1-7, NMS G. 2014.33.10 from Corbie Den, Banffshire, thin sections of a patch of midflank scales: 1, group of scales sectioned in various orientations; 2 , vertical longitudinal section; 3, crown horizontal section; 4, horizontal section through the base; 5, 6, vertical longitudinal sections through articulated scales; 7, crown horizontal section. 8, 9, NMS G.2015.11.3 from Gamrie, Banffshire, isolated midflank scales: 8 , crown horizontal section; 9, vertical section through the base and lower neck, imaged with cross nicols. 10, 11, NMS G.2015.11.2 from Gamrie, Banffshire: 10, vertical longitudinal section; 11, vertical longitudinal

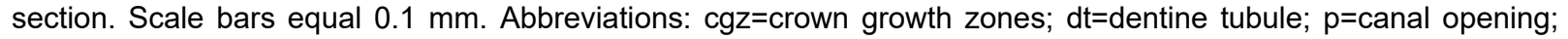
$\mathrm{pc}=$ pore canal; $\mathrm{spc}=$ spiral canal. Arrows indicate anterior direction, where relevant. 

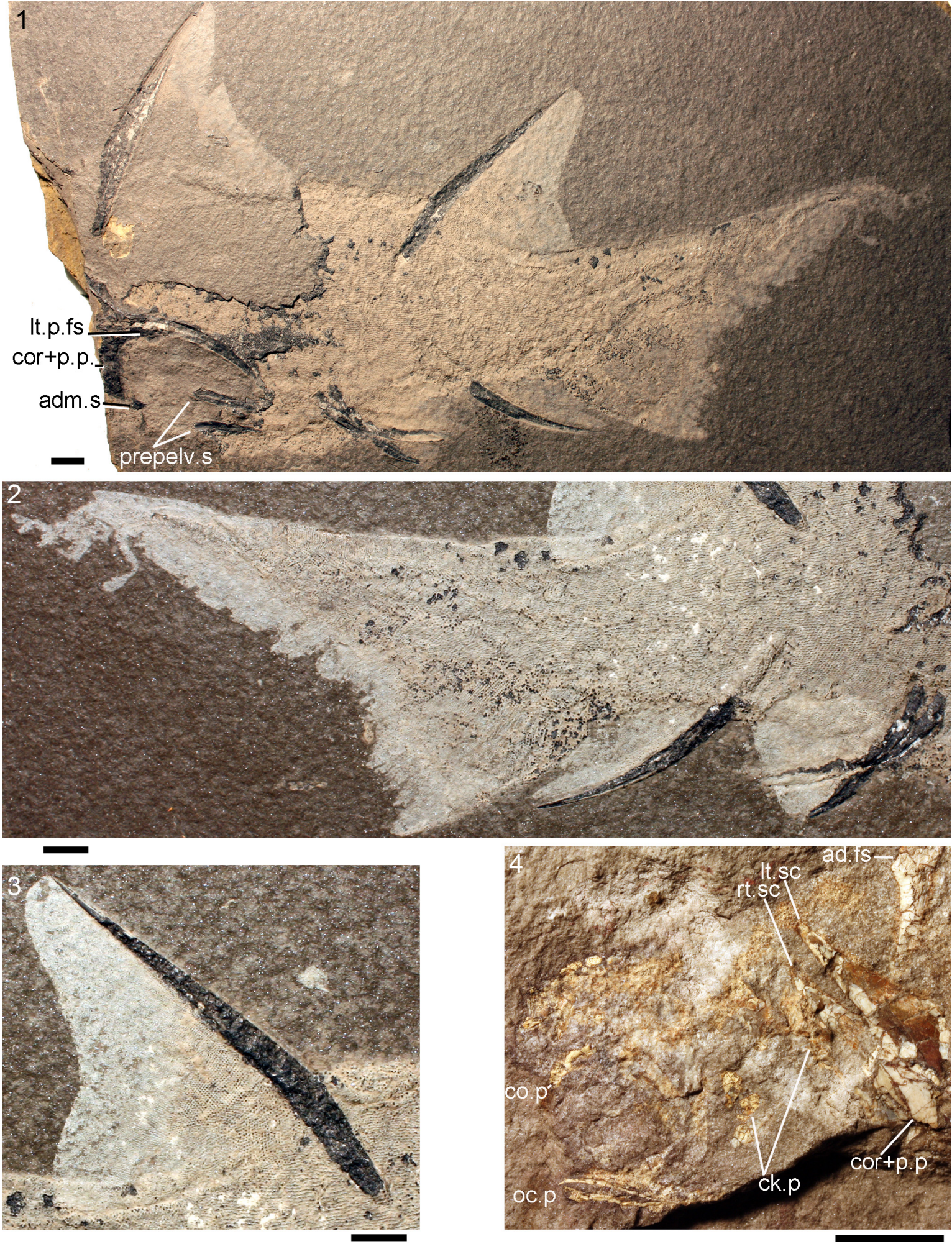

FIGURE 13. Diplacanthus tenuistriatus morphology. 1, NMS G.1897.55.2, counterpart of a headless large specimen from Achanarras Quarry, Caithness; 2, 3, NMS G.1897.55.1 (the part of NMS G.1897.55.2): 2, caudal fin, anal fin spine and fin web and right pelvic fin spine and fin web; 3, posterior dorsal fin spine and fin web; 4, NMS G.1870.14.144 from Tynet Burn, Moray, head and pectoral region. Scale bars equal $1 \mathrm{~cm}$. Abbreviations: ad.fs=anterior dorsal fin spine; adm.s=admedian spine; ck.p=cheek plate; co.p=circumorbital plate; cor=coracoid; It.sc=left scapula; It.p.fs= left pectoral fin spine; oc=occlusal plate; $p . p=$ pinnal plate; prepelv.s=prepelvic spines; rt.sc=right scapula. 
1
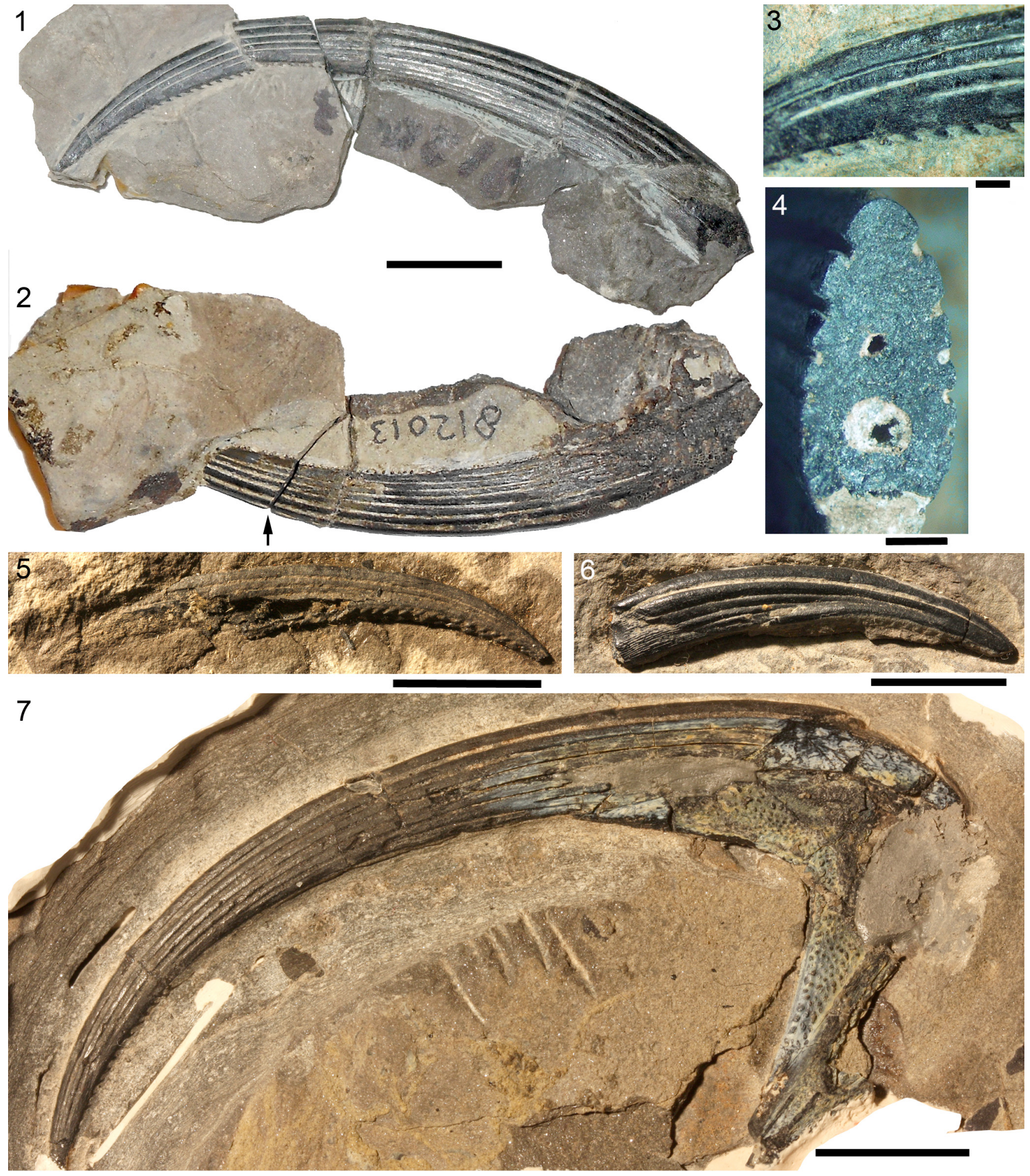

FIGURE 14. Diplacanthus tenuistriatus pectoral fin spines. 1-4, spine QM F58024 from Marwick, Orkney: 1, complete spine, dorsal surface; 2 , ventral surface of spine; 3 , recurved denticles on posterior edges of spine; 4 , transverse natural fracture surface of distal part of spine, at point arrowed in (2); 5, NMS G.1901.153.1 from Appat Hill, Caithness; 6, NMS G.1898.163.2 from Birsay, Orkney; 7, NMS G.2014.4.18, from Marwick, Orkney, spine attached to pinnal plate. Scale bars equal $1 \mathrm{~cm}$ for $1,2,5-7 ; 1 \mathrm{~mm}$ for 3,4 . 

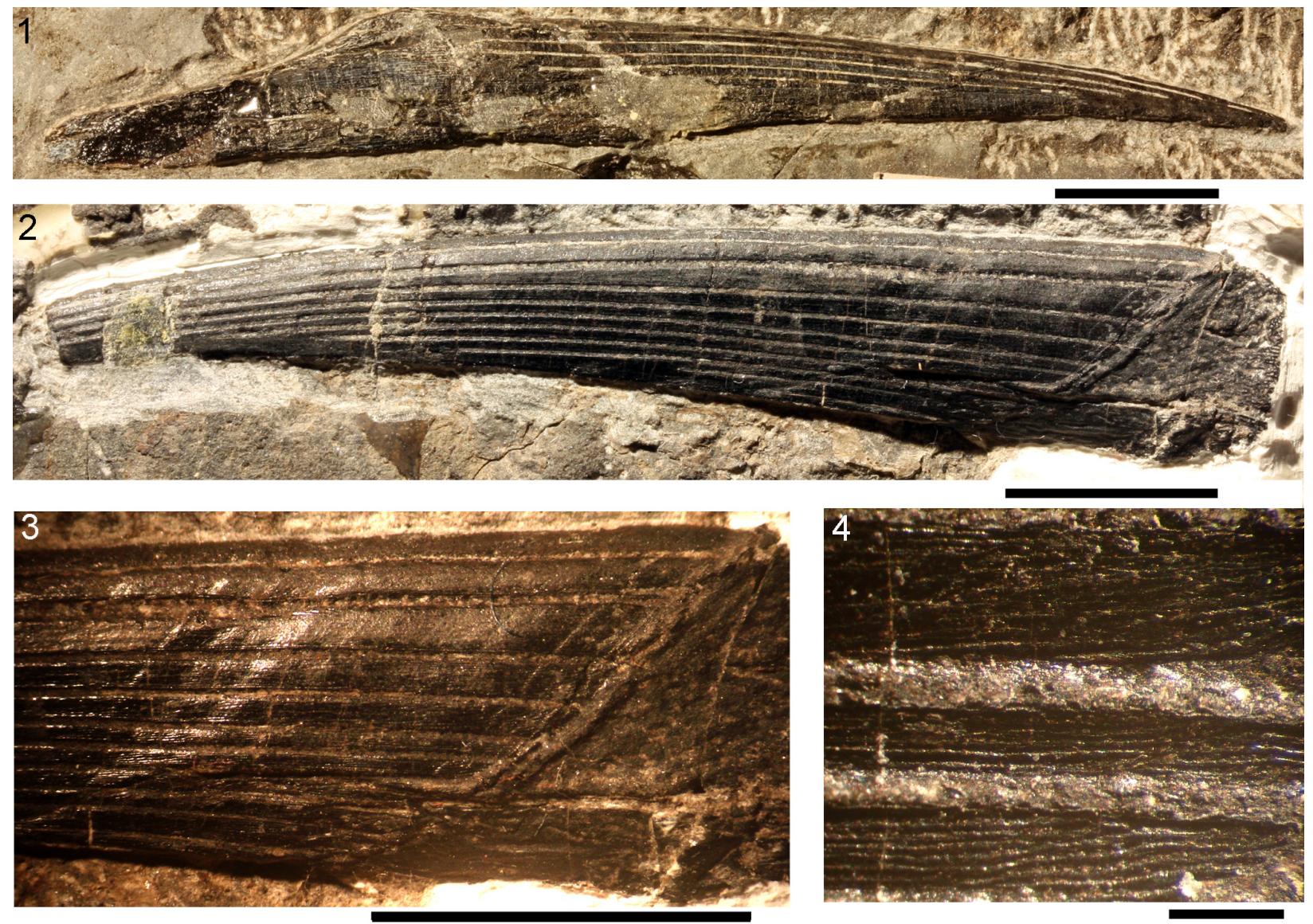

FIGURE 15. Diplacanthus tenuistriatus anterior dorsal fin spines. 1, NMS G.2014.7.35 from Marwick, Orkney. 2-4, NMS G.2014.44.5 from Marwick, Orkney: 2, complete specimen in matrix; 3, magnified view of proximal exserted part; 4 , magnified view of the same area. Scale bars equal $1 \mathrm{~cm}$ in $1-3 ; 1 \mathrm{~mm}$ in 4 .

The large fish NMS G.1897.55.1, 2 (Figure 13.1-3) has a preserved length from the tip of the tail to the base of the anterior dorsal spine of about $280 \mathrm{~mm}$ and an estimated total length of about 350 $\mathrm{mm}$, and the spines are rather short in proportion to the dimensions of the fish, compared with Diplacanthus crassisimus. Isolated spines (Figures 14, 15 ), of roughly the same size as those on NMS G.1897.55.1 and 2, are regarded as mature.

The pectoral spine of Diplacanthus tenuistriatus has a rather strong posteriorly directed curvature and an asymmetrical cross section. The main pulp canal is closed over the total length of the exserted part. The denticles in the double row along the posterior edge are larger distally, regularly spaced c. $0.9 \mathrm{~mm}$ apart, and smaller proximally, c. $0.6 \mathrm{~mm}$ apart (Figure 14.1-3). The pectoral spines are characterized by narrow furrows between the flattened lateral ridges, with a micro-ornament of delicate striations (Figure 14.3). The deep furrows also tend to close over proxi- mally. Ridge number ranges from five to nine, increasing with size of the spines, and often with one more ridge on the upper (dorsally oriented) more convex side (Figure 14.4). The base of the pectoral spine fits in a socket formed mainly by the scapulocoracoid and partly by the lateral edge of the pinnal plate (Figure 14.7). The admedian spine is ankylosed with two elements of the girdle: a dermal plate on the procoracoid and the dermal pinnal plate.

The anterior dorsal fin spine (Figure 15) is the sturdiest of the median spines. In lateral view the spine is almost straight along the posterior side and slightly curved along the leading edge. The inserted part comprises about one fourth of the total length and is subtriangular in shape with a concave anterior margin, deepening towards the insertion-exsertion boundary. The boundary line between these parts is oblique, resulting from the slanting position in life. In cross section, the height:width ratio varies from about 1.5 near the tip 
to about 1.8 near the insertion. Total length of the spine is about 10 times the maximum height in cross section.

The broad, open main pulp canal of the inserted part extends as an open canal over a short distance in the proximal exserted part of the spine, beyond which it is closed. The posterior face over the main pulp canal is slightly concave with a broad central ridge lengthwise along the midline, with a narrow central groove. The leading edge ridge is rounded and extends over the full length of the exserted part. The lateral ridges, almost parallel to the anterior ridge, increase in number proximally associated with the growth of the spine. There are no ridges or only one or two on each side towards the spine tip. The ridges are rounded in cross section distally but become flattened proximally, increasing in number to nine or 10 , comparable to mature anterior dorsal spines of Diplacanthus crassisimus. The number of ridges can vary on either side of the spine. Depth of the furrows between the ribs increases proximally, often closing over completely close to the insertion/ exsertion boundary. Growth lines on the exserted part, parallelling the insertion-exsertion boundary, are visible on better preserved spines (Figure 15.3).

The posterior dorsal fin spine (Figure 13.1, 13.4) is shorter than the anterior dorsal spine, and the number of lateral ridges is considerably less, with a maximum of only four or five per side. The length to maximum depth ratio is c. 13:1; height:width proportion is 1.4 near the tip and 1.3 near the insertion. Both anterior (leading) and posterior (trailing) edges of the spine are 'bent' at the insertion-exsertion boundary, so that the spine is angled back relative to the anterior dorsal spine (Figure 13.1, 13.4). The anal fin spine is strongly curved and more slender than the posterior dorsal spine, with four lateral ridges on each side. Length to maximum depth ratio is c. $16: 1$, height:width proportion varies from about 1.2 near the tip to about 1.0 near the insertion. The main pulp canal remains open over a third of the exserted part.

The paired pelvic fin spines are less strongly curved than the anal spine and are about two thirds its length, with only two or three lateral ridges. The prepelvic spines are relatively small and of the same shape as the admedian spines, being rather flat, sharply pointed near the posteriorly directed tip and broadly rounded near the laterally expanded base.

The very fine striations on the flattened surface of the ridges mentioned by Traquair (1894) occur in all our studied spines, even on the narrow ridges of the admedian spine. In cross sections the striae show as sharp crests, separated by concave, shallow grooves (Figure 16.4). The crests occur at rather irregular intervals, separated between about $40 \mu \mathrm{m}$ and $80 \mu \mathrm{m}$ from the next crest. A conspicuous feature of the striae is that they are not all parallel with the lengthwise direction of the ridges, sometimes being oblique bundles over the full width of a rib, or as a chevron like ornamentation, or as a few radiating lines; they never branch (Figure 15.4).

Histology of the Spines. (Figures 16, 17) In Diplacanthus tenuistriatus the median, pectoral, and admedian spines all have at least one accessory pulp canal above the main canal. This accessory pulp canal is often somewhat irregular in cross section and although much smaller than the main pulp canal, its diameter is relatively large when compared with the same canal in Rhadinacanthus longispinus. The main pulp canals (Figure 16.5, 16.7) lack the well-developed lamellar infill seen in spines of $D$. crassisimus. Trabecular dentine forms the inserted parts of the median and pectoral spines and surrounds the accessory pulp canal, with radially arranged vascular canals extending from the more cancellous inner osteodentine. Ornament ridges are formed of osteodentine with fine dentine tubules radiating out to the surface from a network leading to the vascular canals (Figure 16.3-4). The dentine of the ridges has a sharp boundary with a thin outer layer that covers their exterior surface. It is this thin layer on which the superficial striae are developed, and which can cover over the deep grooves between the ridges (Figure 16.6). Small canals run from the vascular canals and open out in the deep grooves between the ribs.

Shoulder Girdle Complex. (Figures 18, 19, 20) In the endoskeleton, the scapular shaft of the scapulocoracoid has a vertical, swollen ridge between the broad posterior flange and the narrower postbranchial flange (Figure 18.1, 18.4). The ridge is hollow and always calcite filled. A notch separates the postbranchial flange from the coracoid, with scapula, coracoids, and procoracoid forming a single element. The proximal end of the pectoral spine is rigidly fixed in a socket formed by the pinnal plate and scapulocoracoid (Figures 18.9, 19).

The dermal shoulder girdle complex comprises an anterior ventral plate, pinnal plate, admedian spine, with a thin, lamellar plate covering the visceral side of these three elements (Figures 18.4, 19). A wedge of the ventral plate surrounds the 


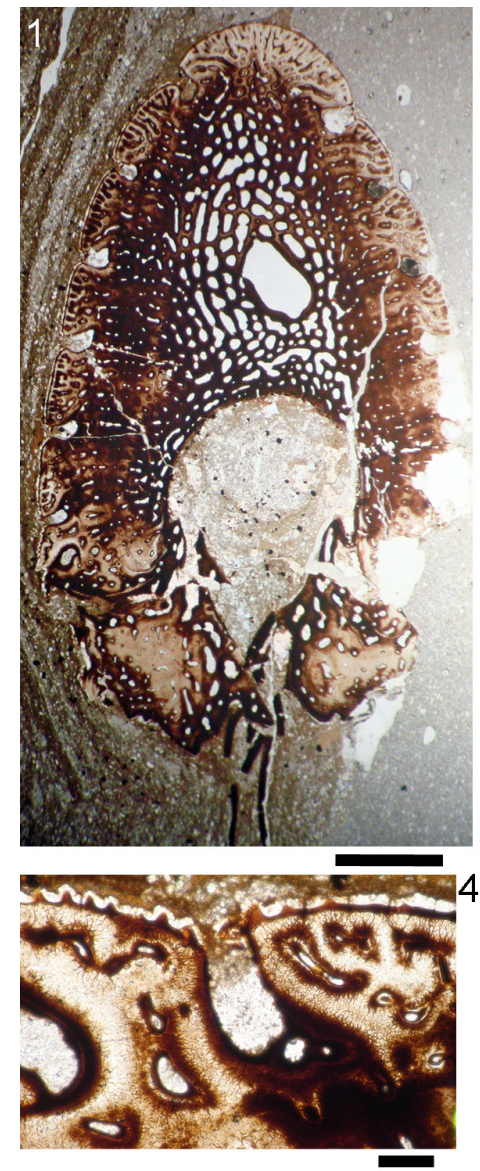

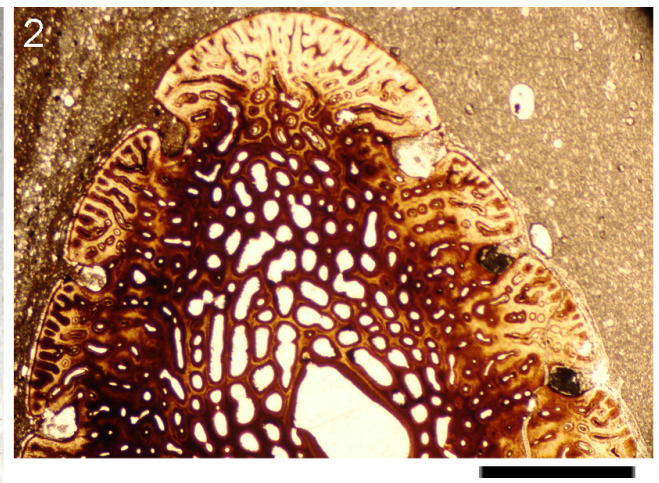

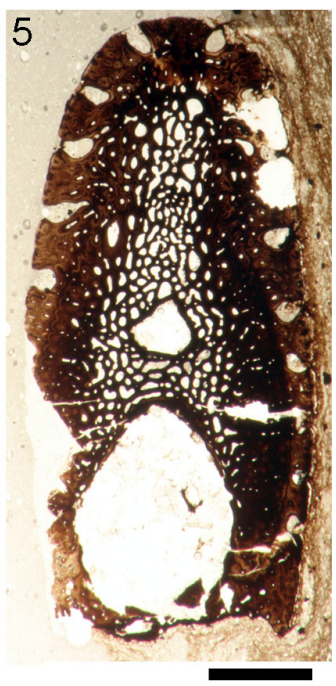

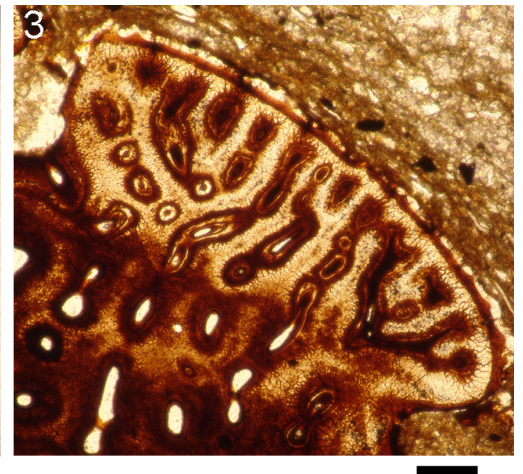

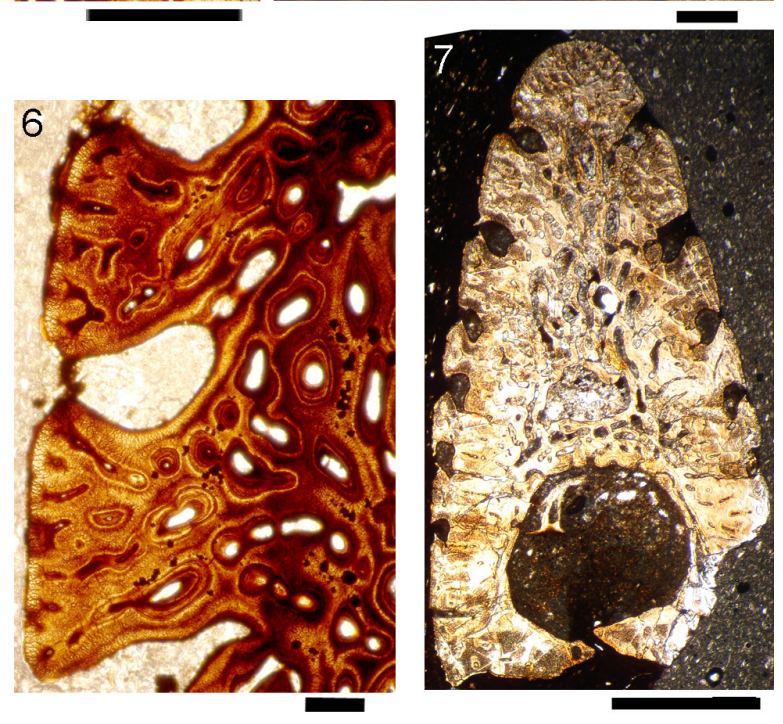

FIGURE 16. Diplacanthus tenuistriatus fin spine histology. 1-4, pectoral spine NMS G.2014.7.36 from Marwick, Orkney; $1-4$, transverse section through the pectoral spine and the posterior end of the pinnal plate; 5,6 , anterior dorsal spine NMS G.2014.7.35 from Marwick Orkney: midspine transverse section. 7, NMS G.2014.33.1, midspine transverse section of anterior dorsal spine from North Ronaldsay, Orkney. Scale bars equal $1 \mathrm{~mm}$ in 1, 2, 5, 7; $0.1 \mathrm{~mm}$ in 3, 4,6 .

proximal part of the admedian spine. The ornament on the ridges of the admedian spine is identical to that of the scales at their bases (Figure 18.2). The pinnal plate lateral to the admedian spine bears ordered, closeset small scales, comparable to normal body scales (Figure 18.3, 18.6-8). The pinnal plate is concave and has a triangular shape.

Morphology of the Scales. (Figures 21.1-3, 22.2$3,23)$ The outline of the scale crowns of Diplacanthus tenuistriatus is roughly identical to those of the other Middle Devonian Diplacanthidae. The anterior margin is evenly rounded, the lateral corners are more sharply rounded, and the somewhat concave posterolateral margins join in a sharp point. The anterior half of the crown is ornamented with U-shaped or V-shaped ridges, the open side anterior (Figure 23). These ridges are fewer than in $D$. crassisimus and much less regularly placed. The ridges in the anterior part of the crown fan out towards the lateral corners, where they often bifurcate. In top view the shape of these ridges is often highly irregular, some may be S-shaped, the next ones curved in different directions. The crown has a high sharp median crest running along the posterior half. The crest starts in the anterior part of the crown with two of the V-shaped anterior ridges joining to form the ridge, with the crest increasing in height from anterior to posterior (Figure 23.8). The transverse ridges are serrated like those of $D$. crassisimus, inclined posteriorly, and overlap ridges behind them on the posterior half of the crown surface. The posterior margins of the scales are only rarely strongly denticulated (Figure 23.11). The neck of the scales is markedly concave all round, with a few buttresses on both anterior and posterior faces which bifurcate into a large number of much smaller ridges, each of them supporting one of the ribs of the crown surface (Figure 23.1, 23.15). In 

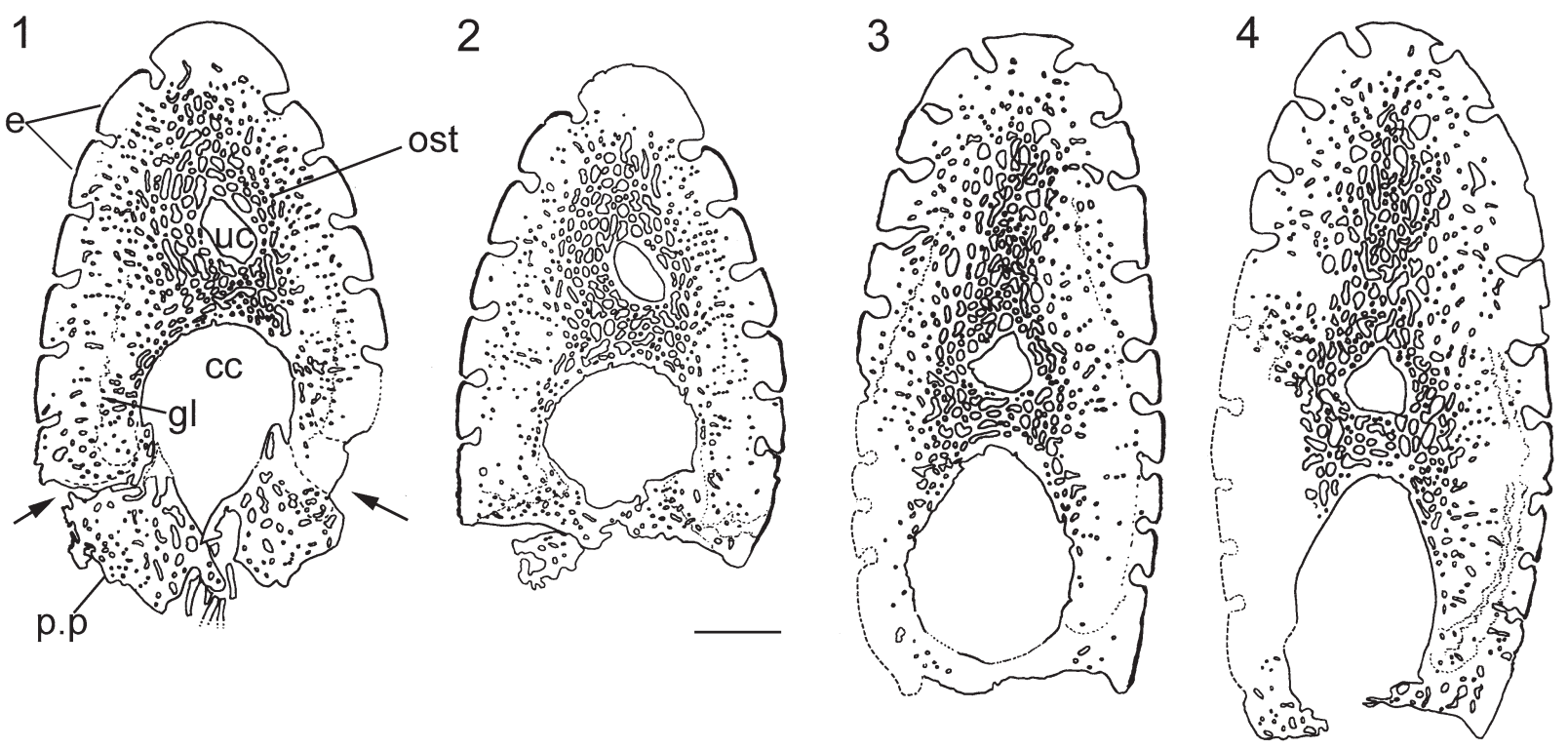

FIGURE 17. Drawings of transverse sections through Diplacanthus tenuistriatus pectoral and anterior dorsal fin spines. 1, 2, pectoral fin spine NMS G.2014.7.36 from Marwick, Orkney: 1, through pectoral spine and posterior end of pinnal plate; 2, slightly distal to the latter section; 3, 4, anterior dorsal fin spine NMS G.2014.7.35 from Marwick, Orkney; 3, midspine; 4, slightly proximal to latter section. Scale bars equal $1 \mathrm{~mm}$. Abbreviations: cc=central pulp canal; $e=$ =nameloid; $g$ l=growth line; ost=osteodentine; $p . p=$ pinnal plate; uc=upper longitudinal canal. Arrows point to junction between pectoral fin spine and pinnal plate.

cross section the neck and base are oval in shape, wider than long. The base and the neck are always below the anterior part of the crown and the posterior part of the crown rises above the level of the rest of the scale. The basal surface of the scale is not usually flat as in $D$. crassisimus, but convex centrally and flattening out towards the marked base-neck rim.

Scale morphology is markedly constant over the flanks, with a sharp transition between body scales and the much smaller scales on the fin webs (Figure 13.3). Fin web scale rows are parallel to the spine on the median fins, and parallel to the body on the pelvic fins (Figure 13.1-3). The position of the lateral line cannot be determined, indicating it is only edged by normal flank scales. The caudal fin shows the same zonation as in other acanthodians such as Euthacanthus macnicoli Powrie, 1864 (Newman et al., 2014, figure 12).

Histology of the Scales. (Figures 21.4-9, 22.4-8, 22.11-16) In Diplacanthus tenuistriatus the ascending canals in the neck and horizontal canals in the crown are narrower than those in $D$. crassisimus and Rhadinacanthus longispinus. Fine dentinal tubules with sparsely distributed lacunae extend from the narrow canals, forming a mesodentinal network. The five to eight crown growth zones each have a separate network (Figure 22.5,
22.13). In the older growth zones, long dentinal tubules reach further towards the crown centre than in younger growth zones (Figure 22.4). As a result the newer ridges grew mainly by horizontal addition, not by superposition of new ridges above older ones.

Two dentine tubules rise up from lacunae in the neck, then loop twice horizontally near the anterior edge of the crown, where they again join into lacunal widenings, regularly spaced along the anterior edge of the growth zone. From these lacunae, one or two long tubules extend towards the centre of the scale below one or two of the grooves between the ridges on the crown surface. Along their length, which may exceed $250 \mu \mathrm{m}$, swollen nodes or lacunae are sometimes present from which short, fine tubules extend out. The long tubules terminate in tufts of repeatedly branching, ever finer tubules, rising up and back into the ridges of the crown surface.

Short horizontal tubules lead off more irregularly occurring lacunae in the posterior parts of the crown. Relatively wide radial canals with a maximum diameter of about 10-12 um open out low between the neck buttresses. There are only two or three of these radial canals in the posterior neck and occasionally one or two shorter ones anteriorly (Figure 22.4, 22.12). The canals lie over the 


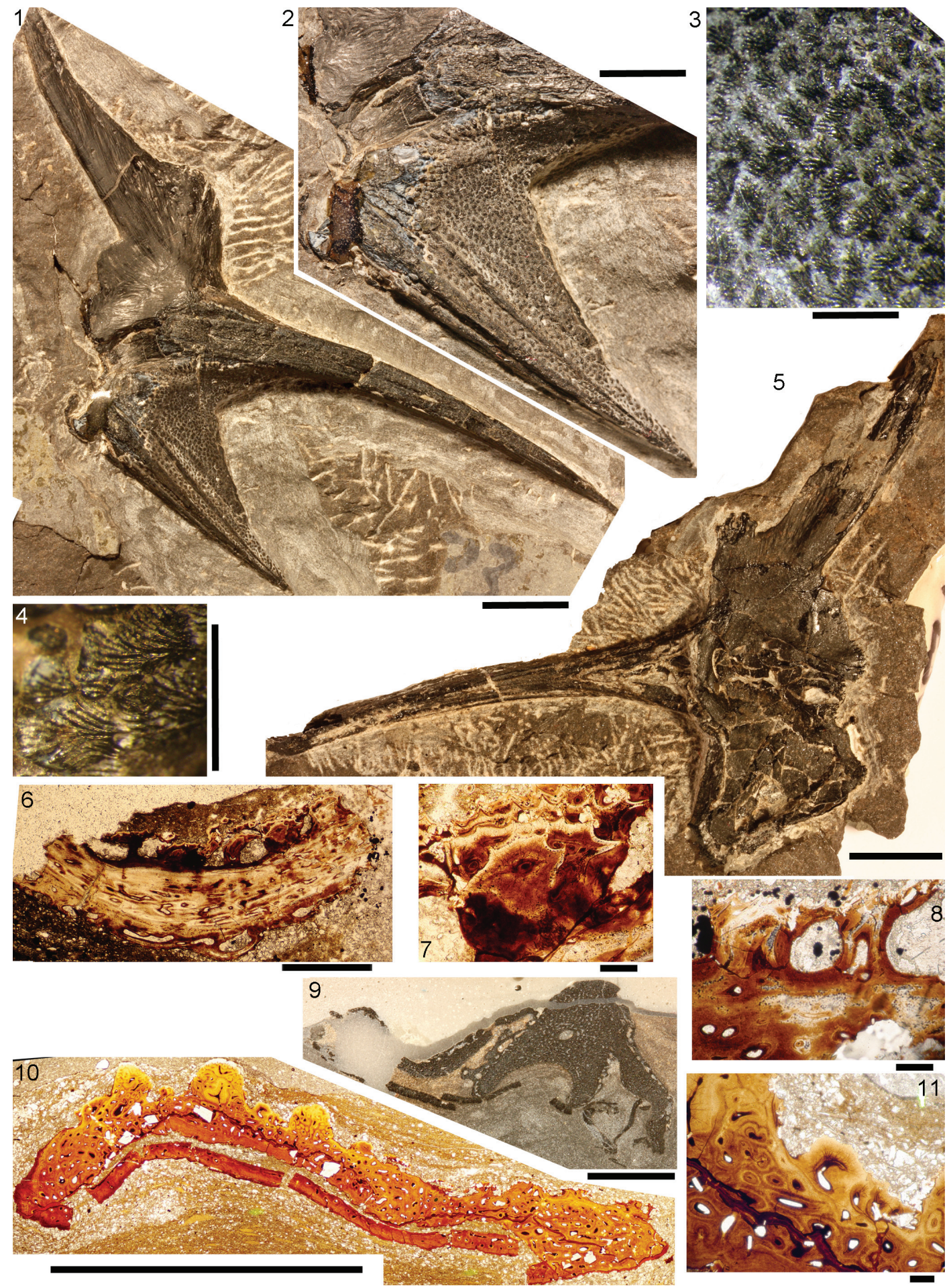

FIGURE 18. Diplacanthus tenuistriatus isolated shoulder girdle complexes. 1-4, NMS G.2014.15.21 from Marwick, Orkney: 1, external surface of scapulocoracoid, pectoral fin spine, pinnal plate and admedian spine; 2, admedian spine; 3, 4, scale-like ornament on pinnal plate; 5, NMS G.2014.15.22 from Marwick, Orkney, internal surface; 6-9, transverse sections of NMS G.2014.4.20 from Marwick, Orkney: 6, pinnal plate; 7, multiple odontode on plate; 8, scalelike ornament; 9 , transverse section through pinnal plate, pectoral fin spine base, scapulocoracoid and perichondral bone sheet; 10, 11, NMS G.2014.4.27 from Flashes, Hoy, Orkney, transverse section through base of admedian spine and inner perichondral bone sheet; 10, whole width; 11, scale-like ornament in groove. Scale bars equal $1 \mathrm{~cm}$ in 1,5; $5.0 \mathrm{~mm}$ in $2 ; 1.0 \mathrm{~mm}$ in $3,4,6 ; 0.5 \mathrm{~mm}$ in 9,$10 ; 0.1 \mathrm{~mm}$ in $7,8,11 ; 0.05 \mathrm{~mm}$ in 4 . 


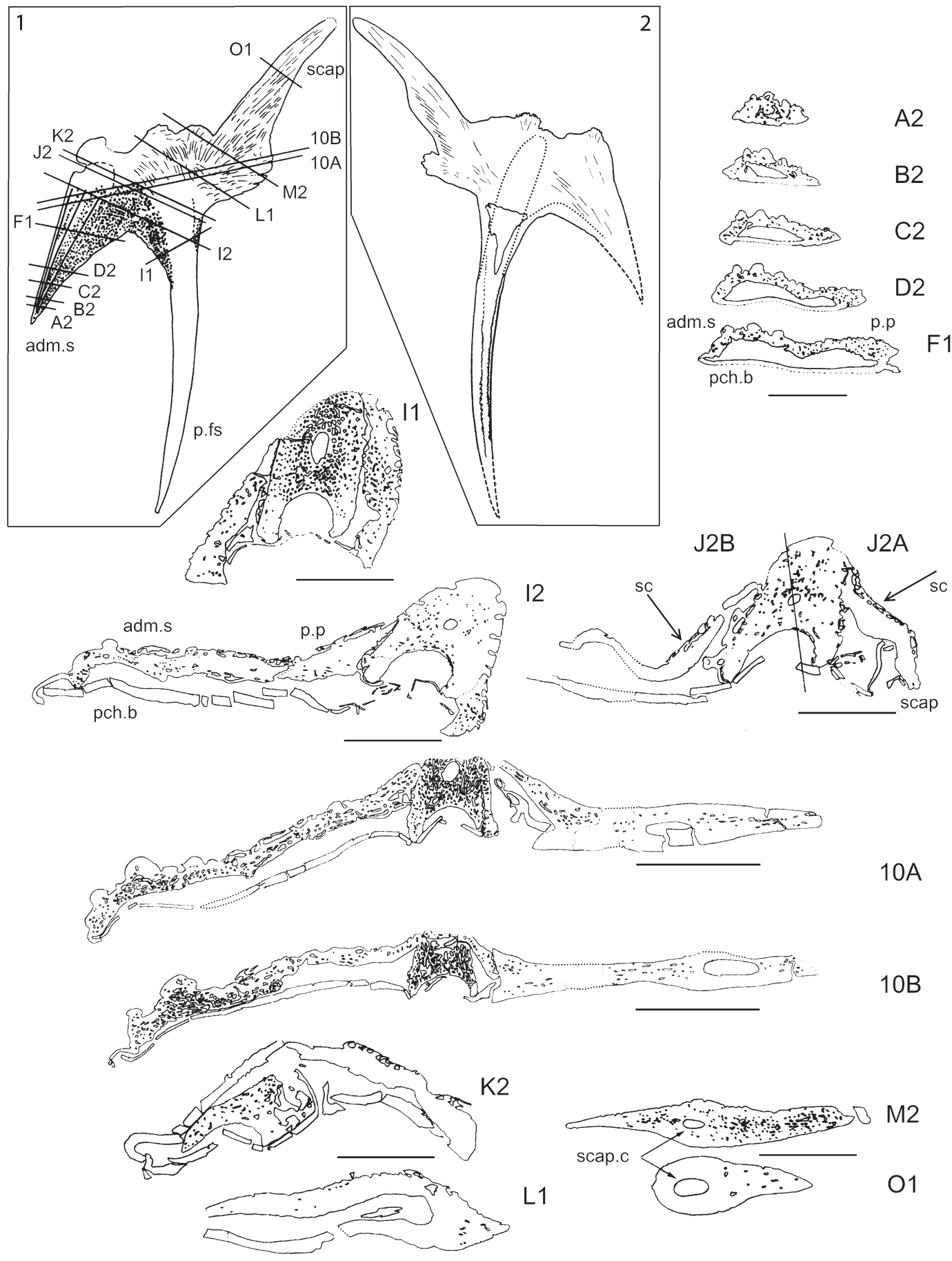

FIGURE 19. Drawings of serial sections through Diplacanthus tenuistriatus shoulder girdle complexes from Marwick, Orkney. 1, schematic drawing of the external view of shoulder girdle complex NMS G.2014.4.21, showing levels at which transverse sections were made. 2, schematic drawing of the inner view of complex NMS G.2014.15.22. A2-F1 is the section series through the admedian spine on NMS G.2014.4.27; 11 is a section through the pectoral fin base enclosed by surrounding plates on NMS G.2014.4.27; I2, J2B, and J2A are sections through the admedian spine, pinnal plate, pectoral fin, base of scapulocoracoid and perichondral bone of the coracoid of NMS G.2014.4.20; 10A and 10B are sections through the girdle complex NMS G.2014.4.23; K2, L1, M2 and O1 are serial sections through the scapulocoracoid and associated structures of NMS G.2014.20.20. Scale bars equal $5 \mathrm{~mm}$. Anatomical abbreviations:

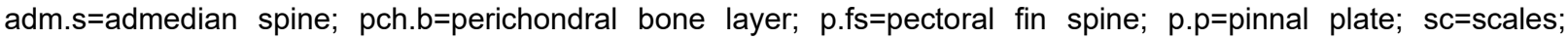
scap=scapula; scap.c=central pulp cavity of scapula shaft. Length given for each spine. 


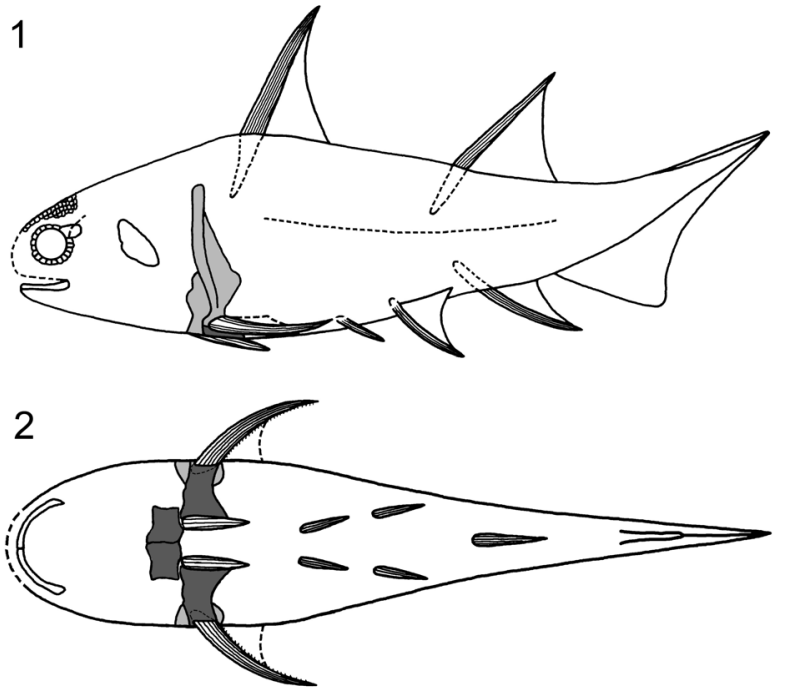

FIGURE 30. Rhadinacanthus longispinus median fin spines from mature fish, transverse section drawings. 1, 2, posterior dorsal spine NMS G.2014.4.33 from the slates west of East Murkle Bay, Caithness: 1, spine showing position of sections; 2 , sections $1-8$. 3, section of posterior dorsal spine NMS G.2014.33.2 from North Ronaldsay. 4, section of anterior dorsal spine NMS G.2014.11.1 from Broad Taing, Orkney. Scale bars equal $1 \mathrm{~cm}$ in $1 ; 5 \mathrm{~mm}$ in 2; $1 \mathrm{~mm}$ in 3,4 .

boundary between the base of the neck and the base cone, with smaller, interconnecting dentine tubules leading off them horizontally and vertically, ascending into the growth zones of the neck. Other fine dendritic dentine tubules, sometimes with lacunal widenings, open directly to the outside of the neck, again between the buttresses, and lead up to form tufts in the growth zones of the neck. Wide circular canals, low in the crown, have narrower canals traversing growth zones and rising up towards the crown surface, branching into finer tubules (Figure 22.4, 22.14).

The top surface of the scale base has a rather flat conical shape (Figure 22.13-16). Cell lacunae are absent, and rare canals of Williamson extend through the base. Laminar layers forming the base are more or less parallel to the lower side, visible as a very faint banding under normal white light. With crossed polars the scale base exhibits conein-cone sheets of isopedin-like light and dark bands, the cones parallel with the top cone (Figure 22.13). Vertical sections show up to seven darker bands, with other banding perpendicular to the parallel bands. These bandings correspond to the layout of Sharpey's fibre bundles through the base (see Burrow, 2001, figure 5).

\section{1}
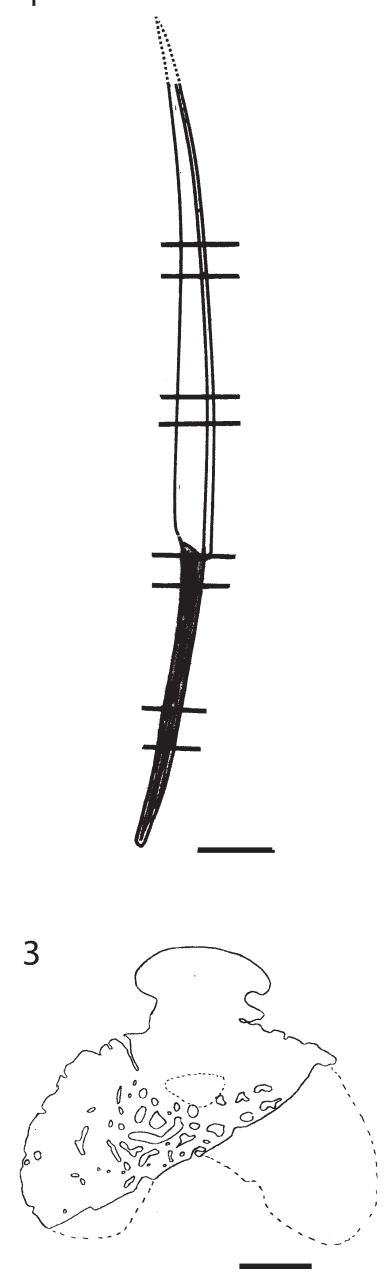

4

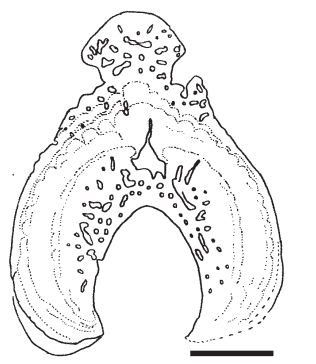

FIGURE 20. Reconstruction of the shoulder girdle region in Diplacanthus tenuistriatus. 1, lateral view. 2, ventral view. Dark grey fill indicates dermal elements, light grey fill indicates endoskeletal elements.

Remarks. Diplacanthus tenuistriatus shows closest similarity to $D$. crassisimus in the layout of the pectoral girdle, spine ornament, and scale structure. Traquair (1894), in his short but concise description of Diplacanthus tenuistriatus, mentioned a number of distinguishing features, mostly concerning the spines. He compared the spines of 
PE Note: Erratum to Burrow et al., 2016

10 April 2016

The caption of Figure 20 was misprinted in Burrow, Carole, den Blaauwen, Jan, Newman, Michael, and Davidson, Robert. 2016. The diplacanthid fishes (Acanthodii, Diplacanthiformes, Diplacanthidae) from the Middle Devonian of Scotland. Palaeontologia Electronica 19.1.10A: 183

palaeo-electronica.org/content/2016/1398-scottish-diplacanthid-fishes

On page 30 , Figure 20 has the caption for figure 30 and a duplicate Figure 30 appears with the caption for Figure 20 (Figure 30 appears correctly on page 42). The following is the correct caption for Figure 20.

FIGURE 20. Reconstruction of the shoulder girdle region in Diplacanthus tenuistriatus. 1, lateral view. 2 , ventral view. Dark grey fill indicates dermal elements, light grey fill indicates endoskeletal elements. 

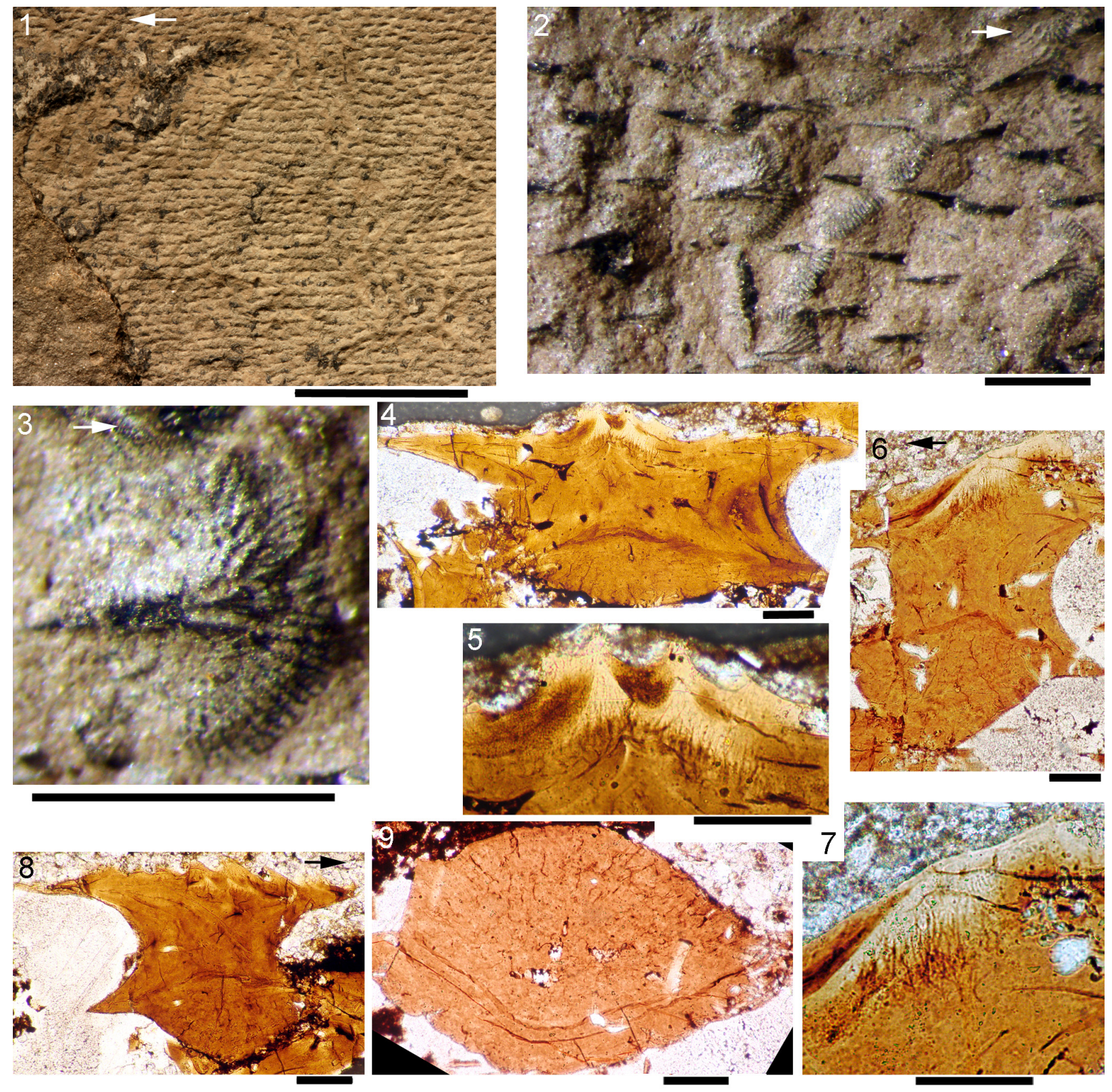

FIGURE 21. Diplacanthus tenuistriatus specimens from Achanarras Quarry, Caithness, squamation and scale histology. 1, NMS G.1897.55.2 (Figure 13.1), impression of squamation anterior to base of posterior dorsal fin spine; 2, 3, NMS G.1897.55.1 (Figure 13.2), squamation above the anal fin, scale crown detail partly obscured by matrix; 4-9, NMS G.1897.55.1, serial sections from patch of midflank squamation: 4,5 , vertical transverse section of scale; 6,7 , vertical longitudinal section of scale; 8 , vertical longitudinal section of scale; 9 , horizontal section near the level of the base/neck rim of scale. Scale bars equal $1 \mathrm{~cm}$ in $1 ; 1 \mathrm{~mm}$ in 2-3; $0.1 \mathrm{~mm}$ in 4-9. Arrows indicate anterior direction, where relevant.

the new species with those of $D$. striatus $(=D$. crassisimus) and stated that in $D$. tenuistriatus the longitudinal ridges on the sides are less numerous and broader, the furrows between the ridges much narrower, and the flattened surfaces of the ribs exhibit a delicate striation. Of these features, the observation that ribs are less numerous is only true in immature specimens.
The pectoral spine of Diplacanthus tenuistriatus has several features in common with the pectoral spines of the other Scottish Middle Devonian diplacanthids: the rather strong posteriorly directed curvature, the asymmetrical cross section, the main pulp canal closed over the total length of the exserted part, and the double row of recurved denticles along the posterior edge. Some of the iso- 

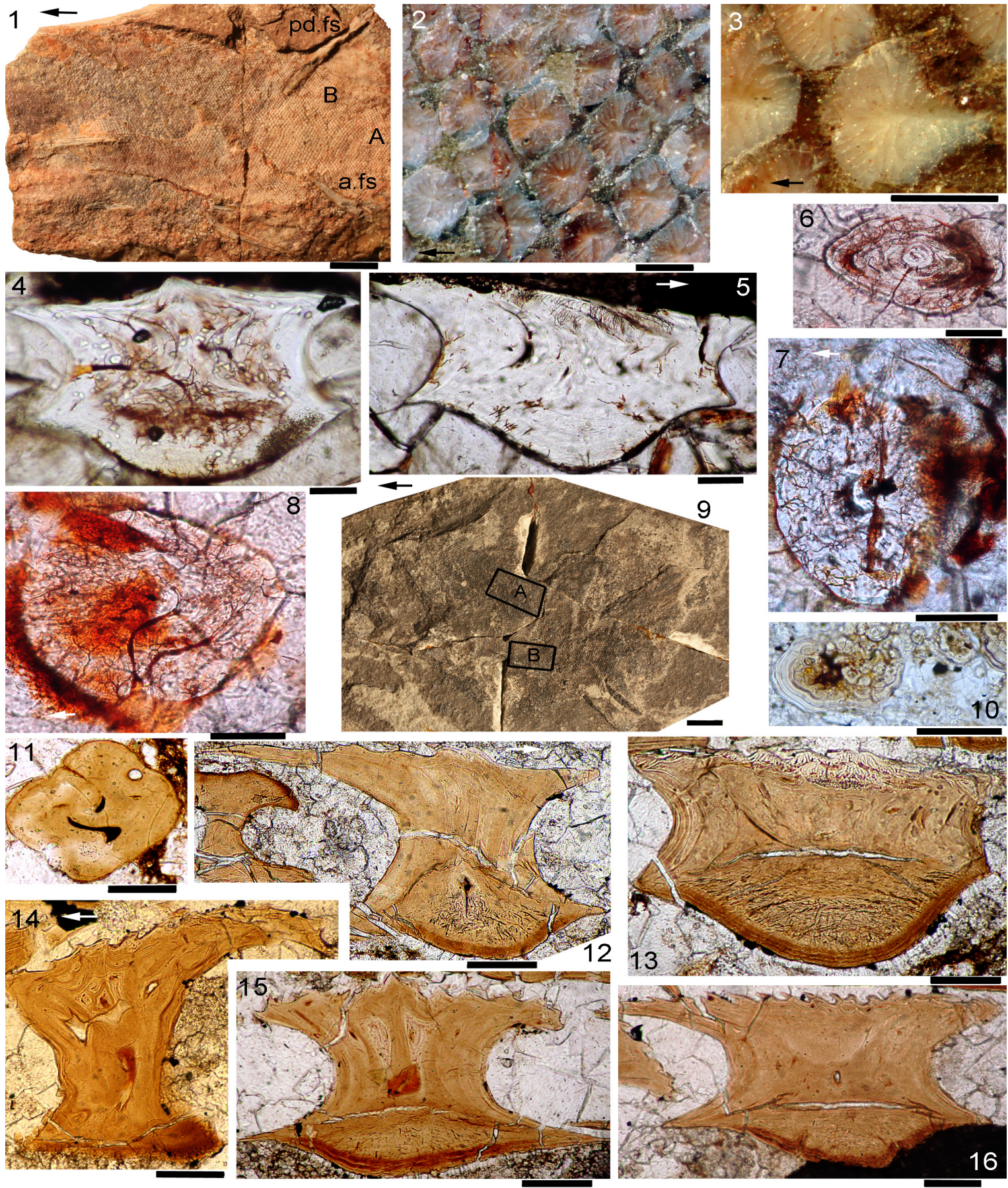

FIGURE 22. Diplacanthus tenuistriatus squamation and histology of scales from Tynet Burn and Gamrie. 1-8, NMS G.Canon Kyle no. 1 from Tynet Burn: 1, postpectoral-caudal peduncle region; 2, mid-body squamation; 3, scale crown; 4 , vertical transverse section of scale from caudal region (area $A) ; 5$, vertical longitudinal section of scale from area $A ; 6$, horizontal section through crown base, scale from posterior to ad.fs (area B); 7, mid-crown horizontal section, area B; 8, upper crown horizontal section, area B. 9-16, NMS G.1892.8.9 from Gamrie, Banffshire: 9, complete specimen; 10-16, sections of scales from upper flank area between ad.fs and pd.fs (area A) and lower flank in front of a.fs (area B); 10, calcified cartilage globules, posterior end of area B; 11, horizontal section through scale neck, posterior end of area $B ; 12$, vertical longitudinal section, area $A ; 13$, vertical transverse section, area $A ; 14$, vertical longitudinal section, area $A ; 15$, transverse section, area $A ; 16$, vertical oblique section, area $A$. Scale bars equal $1 \mathrm{~cm}$ in 1 , 9 ; $1 \mathrm{~mm}$ in 2-3; $0.1 \mathrm{~mm}$ in 4-8, 10-16. Abbreviations: a.fs=anal fin spine; pd.fs=posterior dorsal fin spine. Arrows indicate anterior direction, where relevant. 


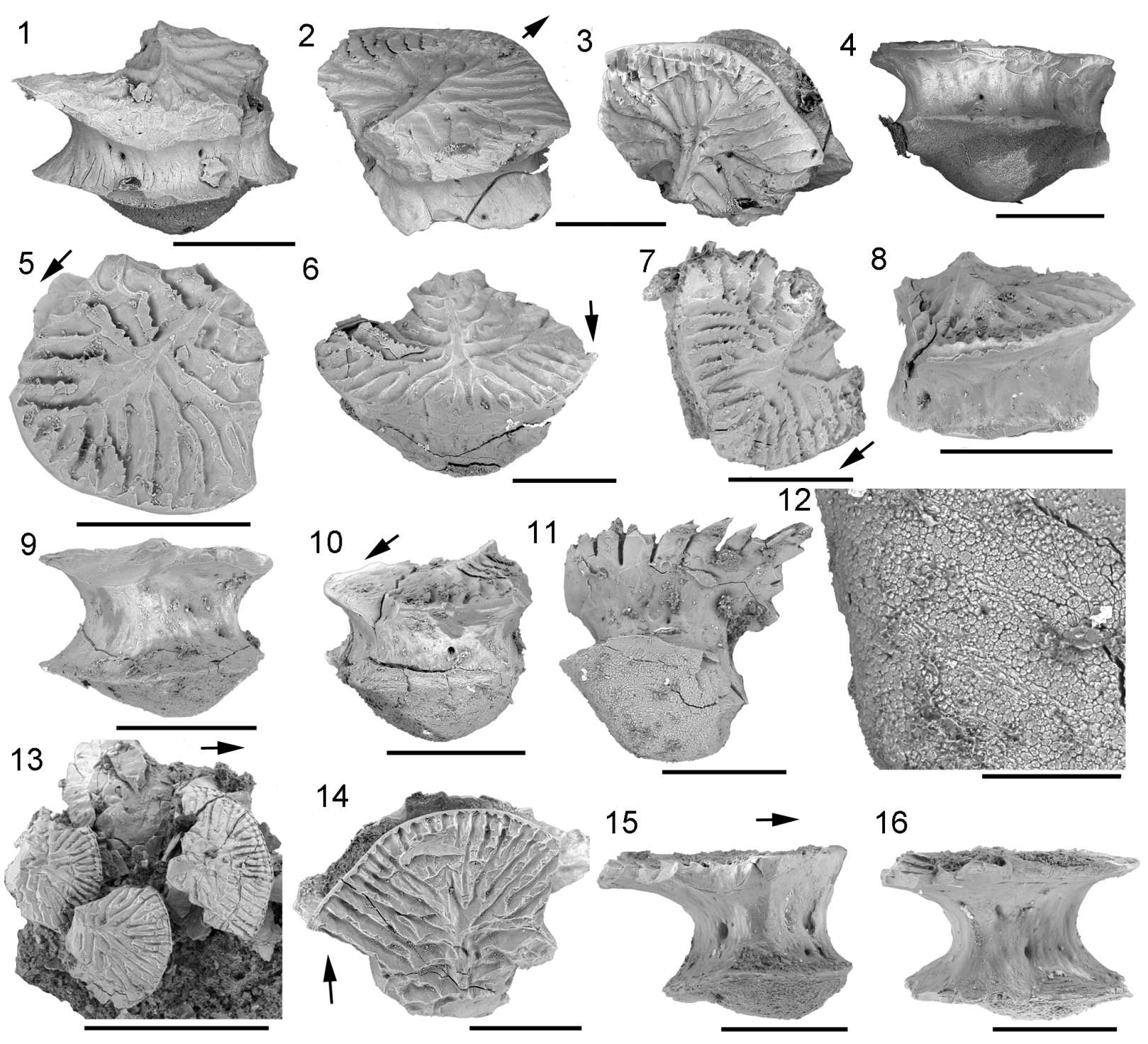

FIGURE 23. Scanning Electron Micrographs of Diplacanthus tenuistriatus scales. 1-4, NMS G.Canon Kyle no. 1 from Tynet Burn, Moray, scales slide NMS G.Canon Kyle no. 1.1, from dorsal side posterior to ad.fs, SEMs: 1, anterior view with broken crown; 2, 3, posterocrown and anterocrown views with end of posterior crown broken off; 4, posterior view. 5-13, NMS G.1892.8.9 from Gamrie, Banffshire, SEMs: 5, 6, 13-16, scales slide NMS G.1892.8.9.17: 5, crown view; 6 , anterocrown view; 13 , patch of scales in matrix, crown view; 14, crown view; 15, lateral view; 16, posterior view. 7-12, scales slide NMS G.1892.8.9.18: 7, crown view; 8, anterior view; 9, posterior view; 10, anterolateral view; 11,12 , posterobasal view and closeup of base surface. Scale bars equal $1 \mathrm{~mm}$ for $13 ; 0.3 \mathrm{~mm}$ for $1-11,14-16 ; 0.1$ $\mathrm{mm}$ for 12.

lated spines from the Middle Devonian of the Baltic, previously assigned to Homacanthus gracilis, are pectoral spines of $D$. tenuistriatus. As noted above, these can be distinguished from those of $D$. crassisimus by the posterior denticles extending most of the length of the spine, and by having fine striations on the ornament ridges (e.g., Gross, 1940, plate 1.2, 1.1, respectively).
Traquair (1894) gave only a short, superficial description of the scales of his new species, stating that they were similar to those of Diplacanthus striatus (= D. crassisimus). The sculpture of the crown surface is completely different from the crown in Rhadinacanthus longispinus. Gross (1973, p. 72, 73) erected a new species Diplacanthus? carinatus for relatively large scales with a more robust sculpture than he recognized in $D$. striatus scales. We 
identify these scales from the Narva-Burtnieki Regional Stages (Eifelian) in the Baltic (e.g., Gross, 1973, plate 38.9) as D. tennuistriatus. More scales from the same deposits which Valiukevičius (1985, plate $1.3,1.5,3.1-2,11.9)$ assigned to $D$. ? carinatus are also here considered to be from $D$. tenuistriatus, as well as scales (including GIT 7303: Kleesment et al., 2006, top figure p. 4) from the Givetian Härma beds of Burtnieki Regional Stage, Karksi outcrop, southern Estonia catalogued as Diplacanthus carinatus.

\section{Genus RHADINACANTHUS Traquair, 1888}

Type Species. Diplacanthus longispinus Agassiz, 1844

Diagnosis. Diplacanthid having fin spines with a smooth rounded ridge along anterior/leading edge separated by a groove from flat sides with $0-4$ ridges; narrow posterior flange on scapula; scale crowns ornamented with parallel or converging ridges leading back from anterior crown edge, usually with denticulated posterolateral edges; scale crown with up to six superposed growth zones composed of mesodentine with long branching tubules extending centripetally from lacunal widenings.

Included Species. Diplacanthus horridus Woodward, 1892; Diplacanthus ellsi Gagnier, 1996.

Rhadinacanthus longispinus (Agassiz, 1844)

Figure 24, Figure 25, Figure 26, Figure 27, Figure 28, Figure 29, Figure 30, Figure 31, Figure 32,

Figure 33, Figure 34, Figure 35, Figure 36, Figure 37

1841 ichthyolite; Miller, pl. 8.1.

1844 Diplacanthus longispinus; Agassiz, p. 34, 42; pl. 14.8, 9.

non 1844 Diplacanthus longispinus; Agassiz, pl. 13.5.

1848 Diplacanthus perarmatus M'Coy; M'Coy, p. 301.

1855 Diplacanthus perarmatus; M'Coy, p. 585, pl. 2B.3.

$1888 \quad$ Rhadinacanthus longispinus (Agassiz 1844), in part; Traquair, p. 512.

1890 Rhadinacanthus longispinus (Ag.); Traquair, p. 482.

1891 Diplacanthus longispinus; Woodward, p. 26, 27; pl. 3.1.

1904 Rhadinacanthus longispinus; Goodchild, p. 595.

1940 Diplacanthus longispinus; Gross, p. 28, fig. 3E, F.

1947 Rhadinacanthus (Diplacanthus) longispinus (Agassiz); Gross, p. 126, textfig. 14, pl. 6.1, 2.
$1988 b$

$1988 b$

1982

1991

1994

1994

1995

1997

1999

1999

2000

2000

2001

2002

2005

2008

2010

2011
Diplacanthus longispinus Agassiz; Waterston, p. 11.

Rhadinacanthus balticus Gross; Gross, $p$. 71, 72, figs. 8J, K, 9A-D, pl. 28.13-15.

Rhadinacanthus longispinus; Saxon, p. 15.

Rhadinacanthus longispinus (Agassiz 1845); Paton, p. 12, 13.

Diplacanthus longispinus Agassiz 1844; Denison, p. 32, fig. 21D-F.

D. balticus (Gross) 1973 [Rhadinacanthus]; Denison, p. 32, figs. 9D, 10F.

Diplacanthus longispinus; Poltnig, pl. 2.1-7.

Rhadinacanthus balticus? Gross; Valiukevičius, p. 32, figs. 2, 4. 5, 6, 7.

Rhadinacanthus balticus; Valiukevičius, $\mathrm{p}$. 603 , table 2.

Rhadinacanthus multisulcatus; Valiukevičius, p. 603, 604, table 2.

Rhadinacanthus balticus; Valiukevičius, $\mathrm{p}$. 78.

Rhadinacanthus multisulcatus Valiukevičius; Valiukevičius, p. 78, 79, fig. 2, pl. 8.9-13.

Diplacanthus longispinus; Andrews, p. 44.

Rhadinacanthus Iongispinus Traquair; Frickhinger, p. 243.

Rhadinacanthus balticus Gross; Valiukevičius, figs. $5,7$.

Rhadinacanthus multisulcatus Gross; Valiukevičius, p. 119, fig. 7.

Rhadinacanthus longispinus; Young, p. 67, figs. 1, 6 .

Rhadinacanthus longispinus; Young, p. 48.

Rhadinacanthus longispinus (Agassiz 1845); Trewin and Davidson, p. 543.

'Rhadinacanthus' Diplacanthus longispinus Agassiz; Dineley, fig. 16.12G.

Rhadinacanthus balticus Gross; Valiukevičius and Kruchek, figs. 1, 4, 5, 6.

Rhadinacanthus multisulcatus Valiuk; Valiukevičius and Kruchek, p. 278, figs. 1, 4, 5.

Rhadinacanthus longispinus; Hanke, Davis, and Wilson, p. 751.

Rhadinacanthus multisulcatus; Valiukevičius, p. 216.

Diplacanthus longispinus (Agassiz); Newman and Dean; p. 3, 4.

Rhadinacanthus multisulcatus; Märss, Kleesment, and Niit, table 1.

Diplacanthus longispinus Agassiz, 1845; Newman, p. 10-11, figs. 15-17.

Rhadinacanthus multisulcatus; Upeniece, p. 18, table 1.2 . 

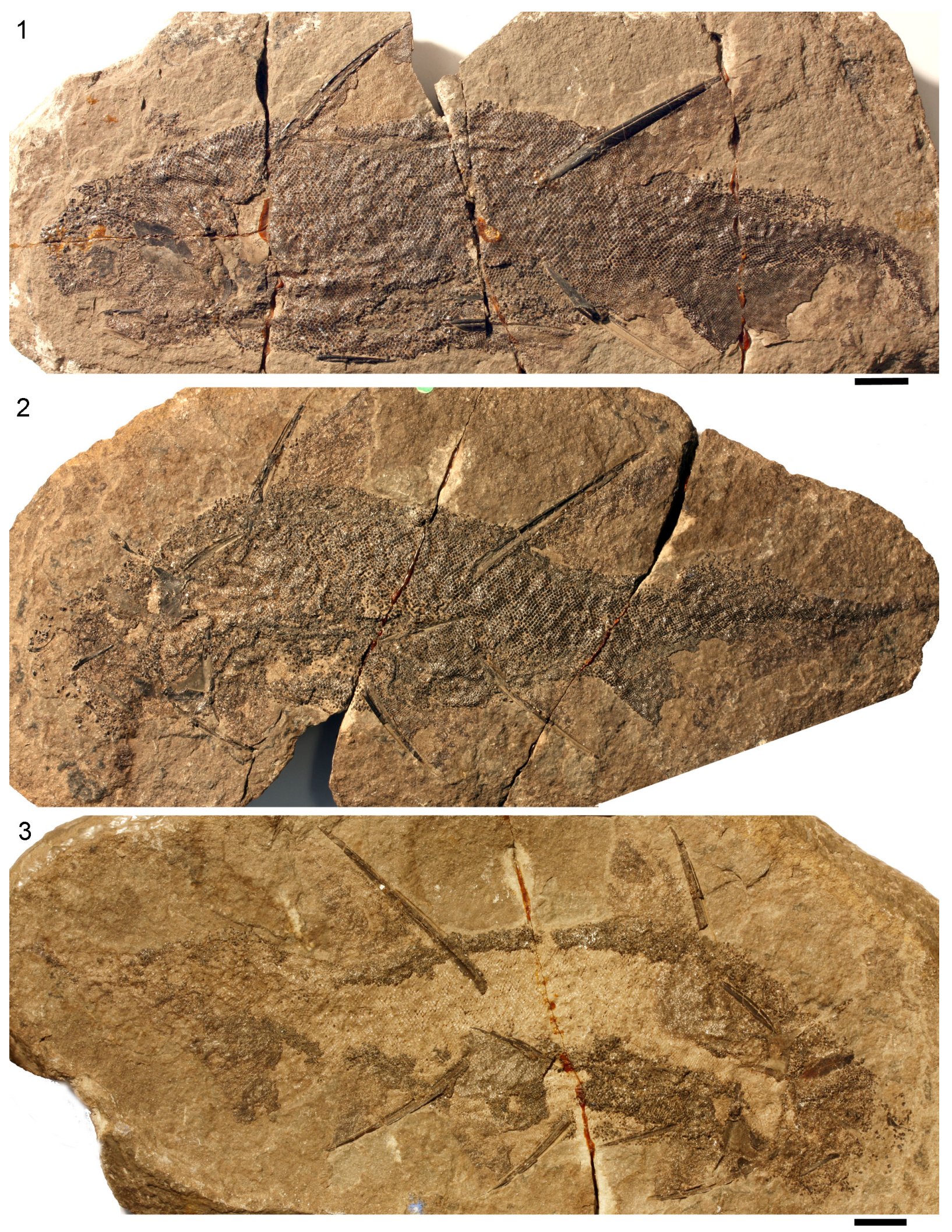

FIGURE 24. Rhadinacanthus longispinus from Gamrie, Banffshire, general morphology. 1, NMS G.1891.92.338; 2, 3, NHM P.4041 from Gamrie, part and counterpart respectively. Scale bars equal $1 \mathrm{~cm}$. 

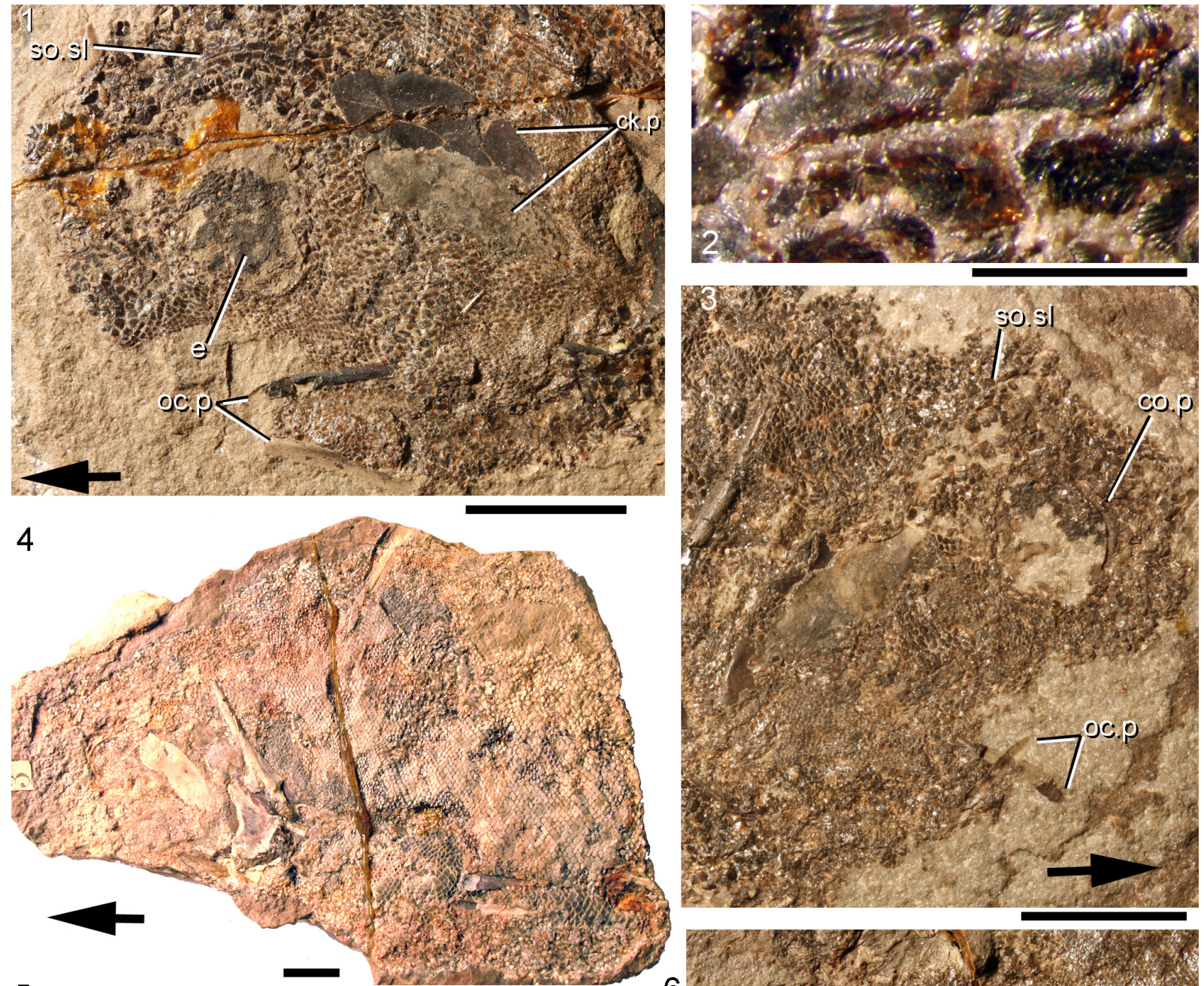

5
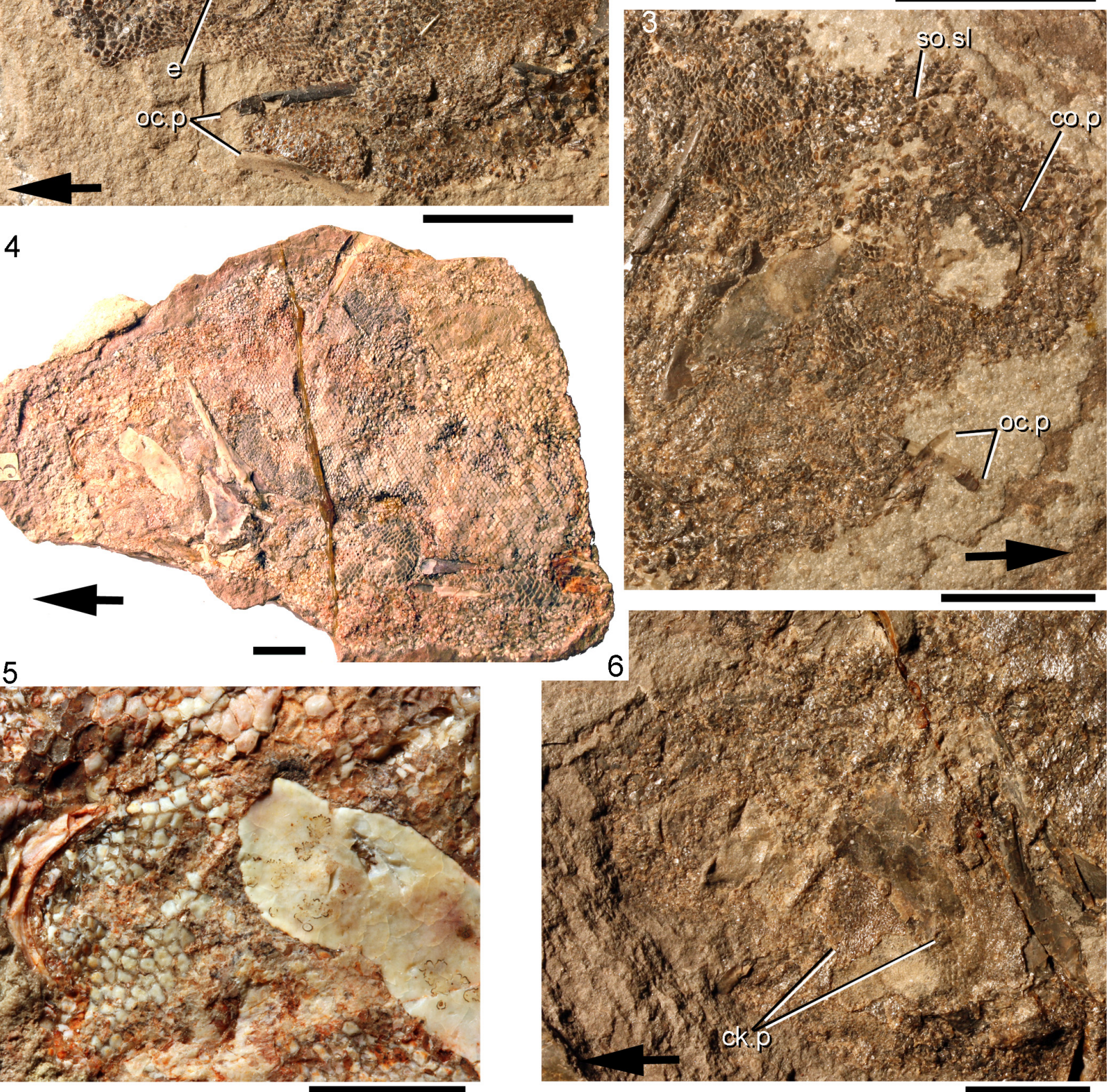

FIGURE 25. Rhadinacanthus longispinus head morphology. 1, 2, NMS G.1891.92.338 from Gamrie, Banffshire; 1, head region; 2, magnified image of sensory line scales; 3, NMS G.1892.8.15 from Gamrie, Banffshire, head region. 4, 5, NHM OR.43276 from Tynet Burn, Moray: 4, complete specimen, head to left; 5, internal surface of right cheek plate, long anterior circumorbital bone, polygonal tesserae on tectal region. 6, NMS G.1892.8.10 from Gamrie, head region. Scale bars equal $1 \mathrm{~cm}$ for $1,3,4,5,6 ; 1 \mathrm{~mm}$ for 2 . Abbreviations: $c k . p=$ cheek plate; co.p=circumorbital plate; $\mathrm{e}=$ eye stain; oc.p=occlusal plate; so.sl=supraorbital sensory line. Arrows indicates anterior direction. 
Diplacanthus longispinus; Newman, Davidson, den Blaauwen and Burrow, p. 742, 743, fig. $2 \mathrm{C}$.

2014 Rhadinacanthus multisulcatus; Plax and Kruchek, p. 32, 36, pl. 3.17.

Holotype. Articulated fish lacking the head, NMS G.1953.4.3 (counterpart NMS G.1859.33.4) from Cromarty.

Referred Material. Articulated specimens of Rhadinacanthus longispinus include: from Gamrie, Banffshire, NMS G.1870.14.143, NMS G.1891.92.336, 337, NMS G.1891.92.338 (part) and NHM P.4041 (counterpart), NMS G.1892.8.10, NMS G.1892.8.12, 13, NMS G.1892.8.15; NMS G.1892.8.16 (counterpart) and NMS G.1892.8.17 (part), NHM P.11760; from Cromarty, Ross and Cromarty, NMS G.1859.33.4; from Tynet Burn, Moray, NHM OR.43276; from Cushnie Burn, Banffshire, NMS G.2002.59.142; from Cruaday Quarry, Orkney, NMS G.1891.92.334 and NMS G 1966.49.9; from Achanarras Quarry, Caithness, NMS.G.2014.4.32. Disarticulated specimens found useful for this study include: from Cromarty, NMS G.2014.44.1; from the west of East Murkle Bay, Caithness, NMS G.2014.4.33; from Clardon Haven, Caithness, NMS G.2014.15.1; from the Thurso area, Caithness, NMS G.1859.33.703; from Taldale Quarry, Caithness, NMS G.1968.5.2; from Marwick, Orkney, NMS G.2014.15.2, NMS G.2014.33.4 and NMS G.2014.33.7; from Broad Taing, Orkney, NMS G.2015.11.1; from North Ronaldsay, Orkney, NMS G.2014.33.2.

Distribution within the Orcadian Basin (Figure 2). Many well-preserved specimens are known from the Moray Firth nodule beds including Cromarty, Eathie, Gamrie, and Lethen Bar, but not Edderton. Several articulated specimens are from Achanarras Quarry, but otherwise in Caithness only rare, disarticulated spines have been collected from some coastal localities (e.g., Castletown and the coast east of Thurso). From Orkney a few rare articulated specimens are known from the Sandwick fish bed. As in Caithness, spines are also found in the sediments exposed along the coast, especially in beds from the Upper Stromness series. Scales of Rhadinacanthus longispinus are also commonly found in coprolites from both Orkney and Caithness, often in beds where isolated spines were collected. A spine NMS.G.2014.33.2 (Figure 27.6) was recently found in the Middle Rousay Formation at North Ronaldsay together with the placoderm Millerosteus minor.

Diagnosis. Diplacanthid having fin spines with a leading edge ridge and smooth flat sides; posterior dorsal fin spine longer than anterior dorsal spine; pectoral fin spine almost straight with minute posterior denticles; large ornamented cheek plate about a third the length of the head plus branchial region; one large thin circumorbital plate anterodorsal to the orbit.

Description. Head Region. (Figures 24, 25) The tectal region of the head is covered with polygonal tesserae, with smaller scales and/or tesserae over the rest of the head and branchial region. Elongate scales line the supraorbital sensory canal (Figure 25.2). The only larger dermal structures are the thin circumorbital plates extending around a third of the anterior circumference of the orbit, the occlusal bones on the lower jaws, and relatively large ornamented cheek plates extending about a third the length of the head and branchial region. The cheek plates are ornamented with small flat tubercles or short ridges (Figure 25.6). The length of the occlusal plates is equal to the diameter of the orbit (Figure $25.1,25.3$ ). There is no sign of a postorbital plate, and no evidence is visible indicating the position of the branchial arches.

Morphology of the Spines. (Figures 24, 26) In Rhadinacanthus longispinus, the median spines are relatively long and slender structures. The anterior dorsal spine (Figures 24, 26.1) is slightly shorter than the posterior one (Figures 24, 26.3) and both are slightly curved posteriorly. The posterior dorsal fin spine measures about a quarter the length of the fish. The anal fin spine (Figures 24, 26.4) is more strongly recurved than the two dorsal spines, and is positioned almost diametrically opposite the posterior dorsal. The anal spine is slightly shorter than the anterior dorsal spine. The pelvic and pectoral spines are of almost identical length (Figures 24, 26.5), both shorter than the anal spine, and each about half the length of the posterior dorsal. The prepelvic spines are about half the length of the pelvic spines, and the admedian spines are about a quarter the length of the pelvic spines (Figure 24).

All median spines have a relatively long inserted part, showing the identical narrow, parallel ribs which typify all diplacanthiforms (Newman et al., 2012; Figure 26.2). All spines have a broad evenly rounded leading edge ridge, separated by a single deep groove from the side wall. In cross section the sides are rather flat to slightly convex. Towards the base the posterior face widens, giving the cross section a roughly triangular shape. In cross section the exserted part of the anterior dorsal fin spine is rather high, with the height:width ratio ranging from $c$. 1.6 near the tip to about 1.3 

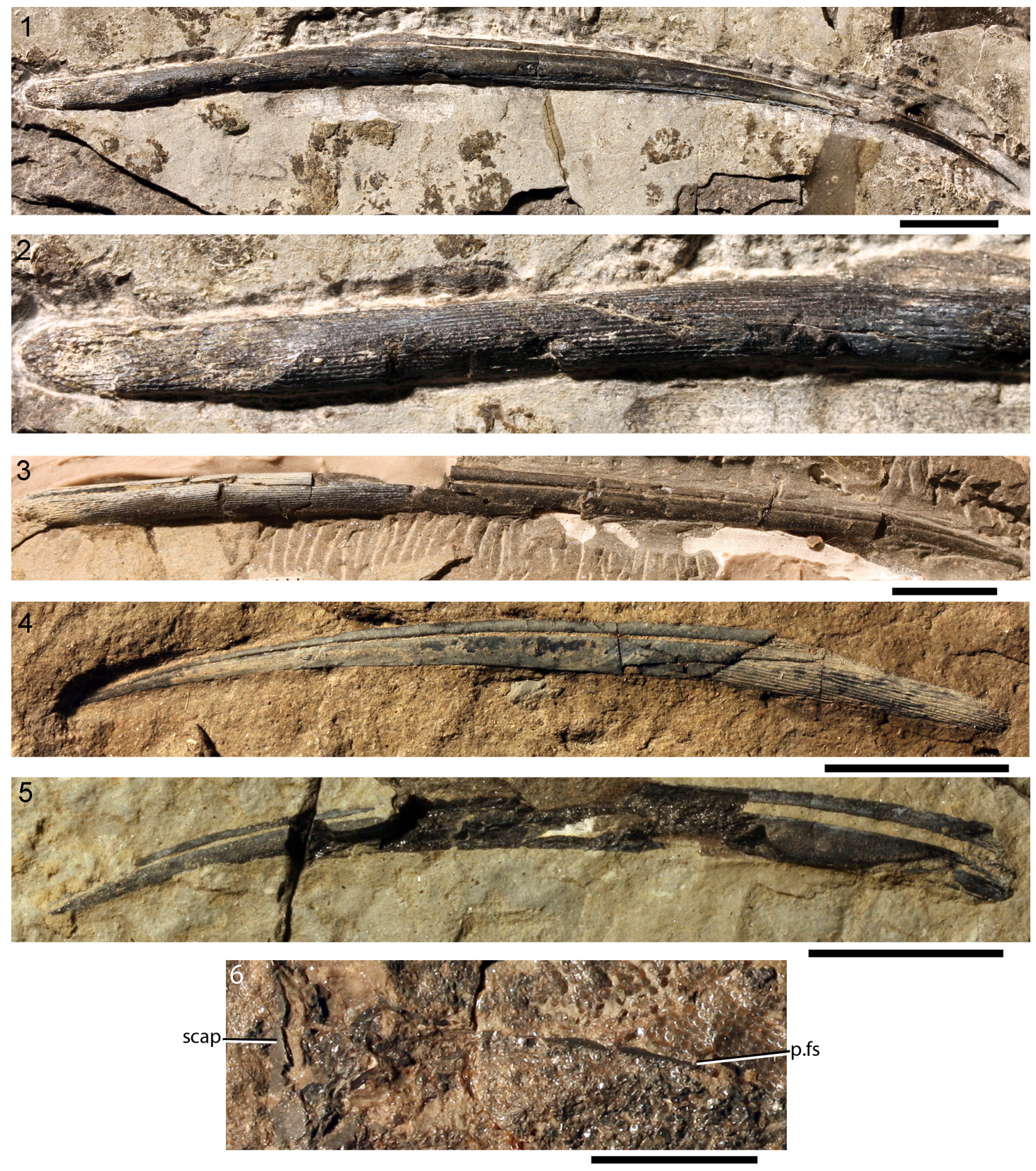

FIGURE 26. Rhadinacanthus longispinus spine morphologies. 1, 2, isolated anterior dorsal fin spine of NMS G.2014.33.4 from Marwick, Orkney: 1, whole spine; 2, long insertion zone showing fine parallel ribs; 3, posterior dorsal fin spine of NMS G.2014.33.7 from Marwick, Orkney; 4, anal fin spine of NMS G.1859.33.703 from Thurso, Caithness; 5, pectoral fin spine of NMS G.1968.5.2 from Taldale Quarry, Caithness; 6, denticulated posterior of pectoral fin spine on specimen NMS G.1870.14.143 from Gamrie, Banffshire. Scale bars equal $1 \mathrm{~cm}$. Abbreviations: p.fs=pectoral fin spine; scap=scapula. 

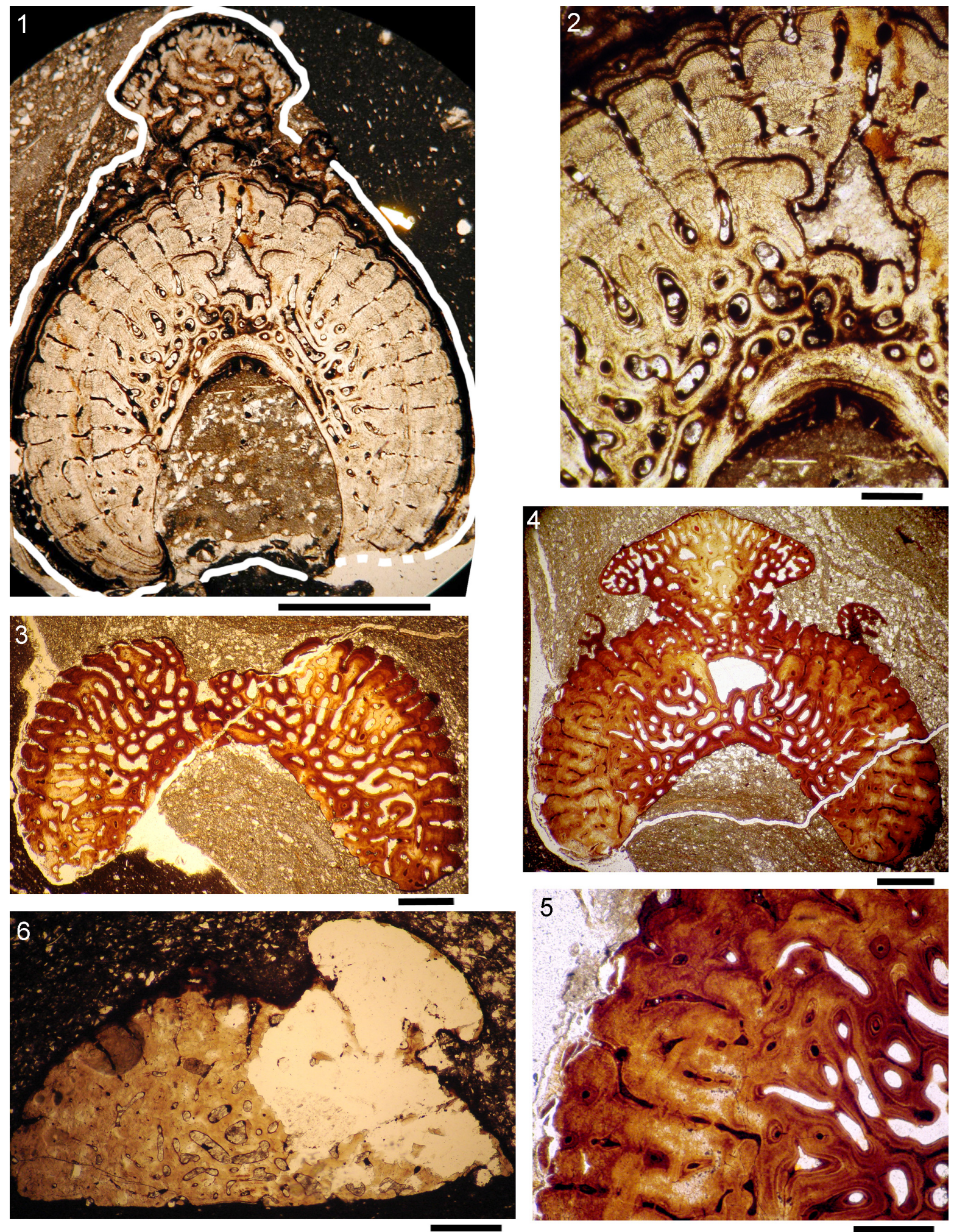

FIGURE 27. Rhadinacanthus longispinus dorsal spine histology. 1, 2, transverse section of anterior dorsal fin spine NMS G.2015.11.1 from Broad Taing, Orkney: 1, whole section indicated by white line; 2, magnified area; 3-5, transverse sections of posterior dorsal fin spine NMS G.2014.4.33 from the slates west of East Murkle Bay, Caithness (Mey subgroup): 3, section through insertion area; 4, 5, section through exserted part of spine; 6 , transverse section of posterior dorsal spine NMS G.2014.33.2 from North Ronaldsay (Rousay Beds). Scale bars equal $1 \mathrm{~mm}$ in 1, 3, 4, 6; $0.1 \mathrm{~mm}$ in 2, 5 . 

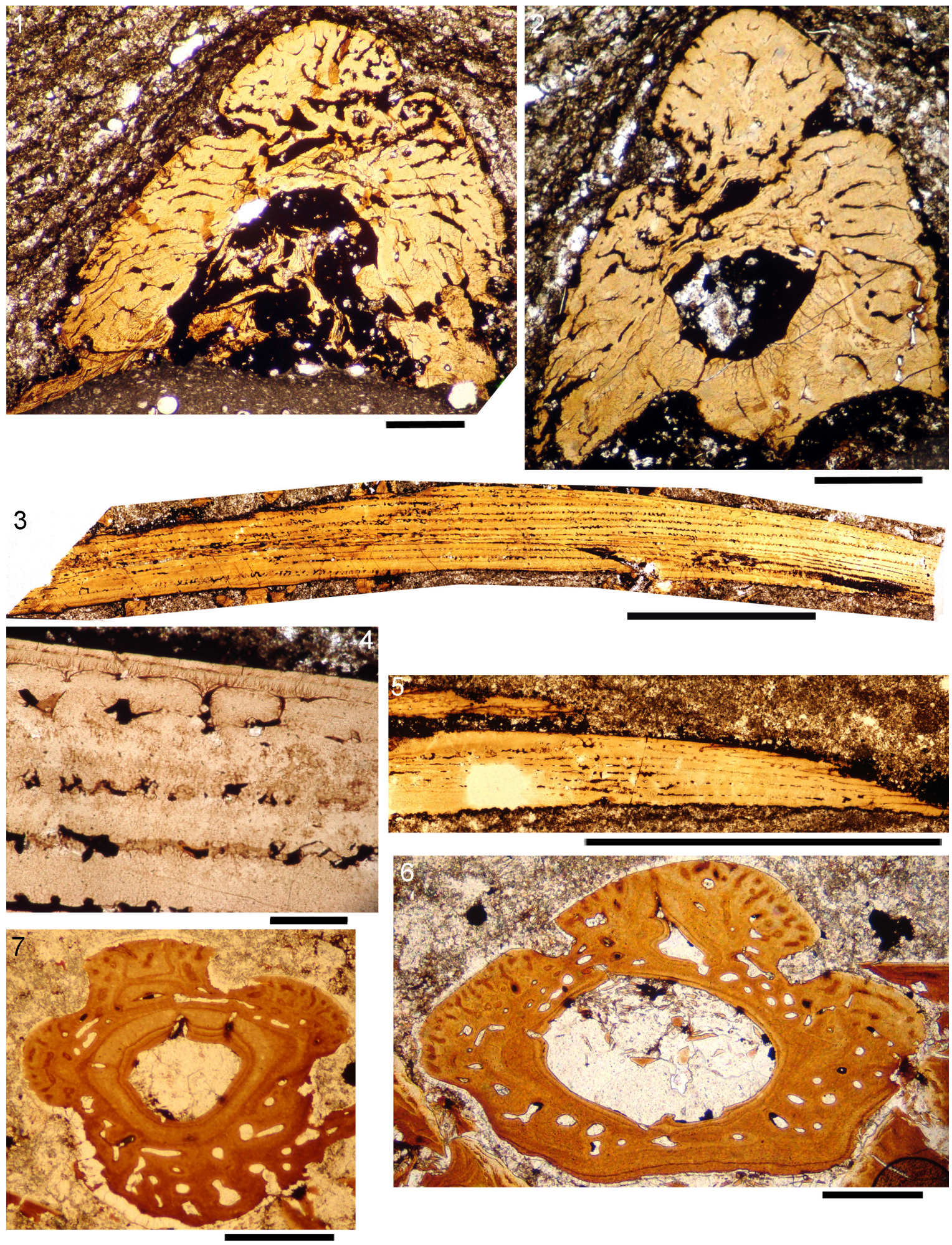

FIGURE 28. Rhadinacanthus longispinus paired and anal spines histology. 1-5, sections of spines on articulated fish NMS G.2014.4.32 from Achanarras; 1, transverse section of pectoral fin spine just distal to insertion area; 2, more distal transverse section of pectoral fin spine; 3,4 , longitudinal section of proximal half of anal fin spine; 5 , longitudinal section of distal half of pelvic fin spine; 6, 7, NMS G.2014.44.1 from Cromarty, Ross and Cromarty, section through partial articulated specimen; 6 , transverse section of pelvic fin spine; 7 , transverse section of prepelvic spine. Scale bars equal $1 \mathrm{~cm}$ in $3 ; 0.5 \mathrm{~mm}$ in $1-2,5-7 ; 0.1 \mathrm{~mm}$ in 4 . 


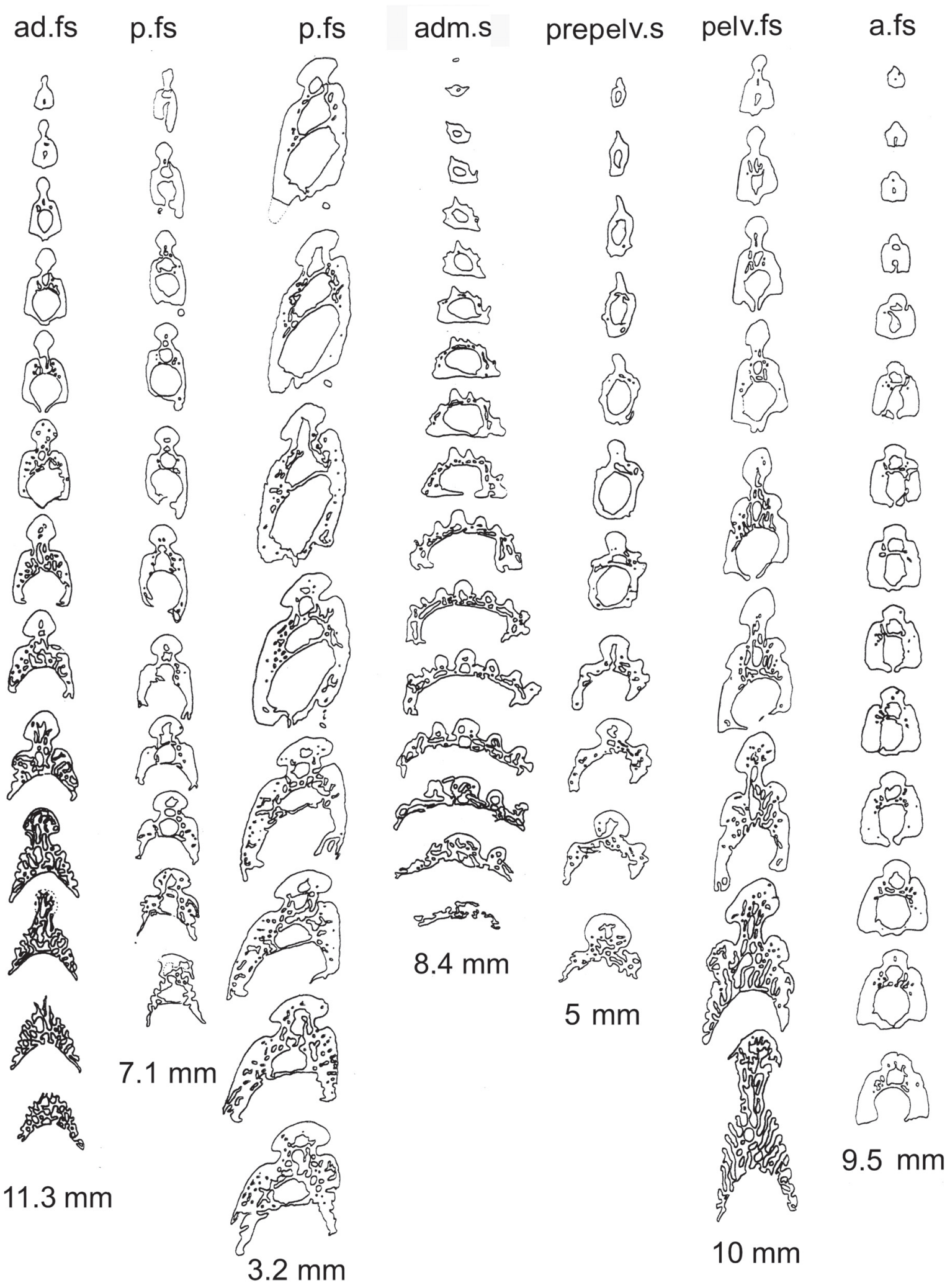

FIGURE 29. Rhadinacanthus longispinus, from a small bonebed (NMS G.2014.15.1 is a sample) at Clardon Haven, Caithness, spine histology. Drawings of Sollas serial sections of various spines from juvenile fish. Abbreviations: adm.s=admedian spine; ad.fs=anterior dorsal fin spine; a.fs=anal fin spine; pelv.fs=pelvic fin spine; $p . f s=p e c t o r a l$ fin spine; prepelv.s=prepelvic spine. 

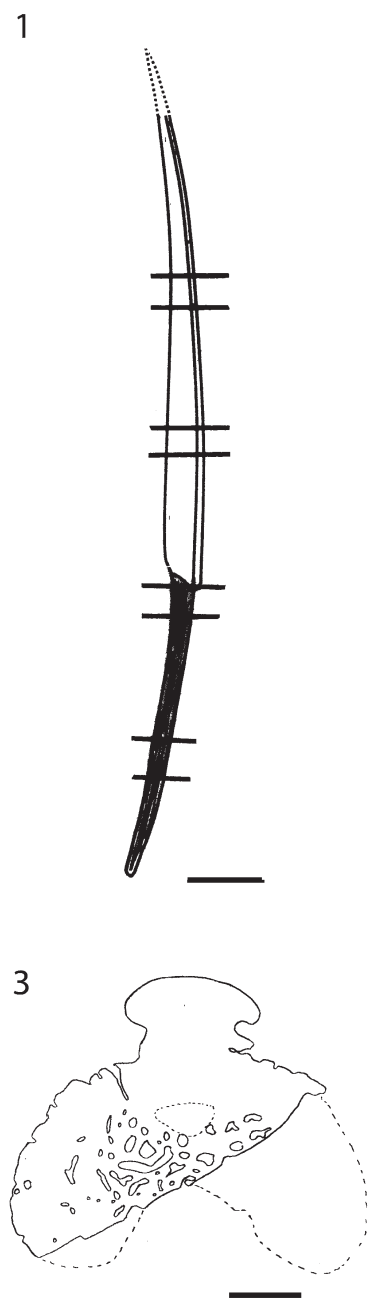

4

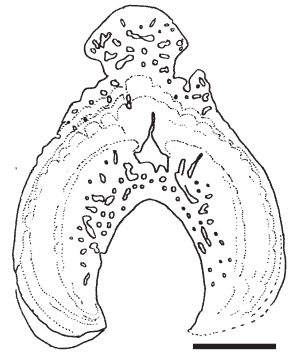

FIGURE 30. Rhadinacanthus longispinus median fin spines from mature fish, transverse section drawings. 1, 2, posterior dorsal spine NMS G.2014.4.33 from the slates west of East Murkle Bay, Caithness: 1, spine showing position of sections; 2 , sections 1-8. 3, section of posterior dorsal spine NMS G.2014.33.2 from North Ronaldsay. 4, section of anterior dorsal spine NMS G.2014.11.1 from Broad Taing, Orkney. Scale bars equal $1 \mathrm{~cm}$ in $1 ; 5 \mathrm{~mm}$ in $2 ; 1 \mathrm{~mm}$ in 3,4 . towards the insertion/exsertion boundary. Length:maximum depth ratio is $18-21$. The posterior dorsal fin spine has an almost circular cross section towards the insertion/exsertion boundary. The height:width ratio for this spine ranges from 1.4 near the tip to about 0.9 in the proximal exserted part, and it is extremely slender with a length:maximum depth ratio c. 30 . The anal fin spine height:width ratio ranges from c. 1.4 about midspine to c. 1.3 in the proximal exserted part, and length:maximum depth ratio is c. 20 . The dorsal and anal spines have an open main pulp canal in the proximal exserted part extending one-third to one-fifth of the total exserted length. In distal parts the main pulp canal is closed over, and often has a narrow median sulcus. In the inserted part, a deep groove, triangular in cross section, runs over the total length along the posterior face. The inserted part of the median spines has a distinctive groove near the base along the anterior side (Figure 30), which leads into the single accessory pulp canal, typical of the median spines in Rhadinacanthus longispinus. This open accessory pulp canal along the deepest inserted part is closed over in the more distal, but still inserted part of the spines.

In the relatively short and almost straight pelvic spines, the anterior rib is a prominent structure, with only short sides below the large grooves. These spines lack a clearly delineated inserted part. In cross section the pelvic spines exhibit a slight asymmetry. The height:width ratio ranges from c. 1.1 distally to c. 0.9 proximally. The prepelvic spines are slightly higher than wide towards the tip, but broad and flat proximally with an open, shallow main pulp canal. The leading edge ridge is again a prominent feature, the sides having two smaller, well-rounded ridges paralleling it. In their proximal parts, the prepelvic spines are broader than high with a height:width ratio c. 0.7 or less. The admedian spines resemble the prepelvic spines, with a prominent, rounded leading edge ridge and just one well-rounded ridge on each side. Towards the base, the spine is much wider than long, with height:width ratio c. 0.3 .

The pectoral spines of Rhadinacanthus longispinus are always asymmetrical, one side flatter than the other and extending further posteriorly. The minute, recurved denticles along the posterior edges (Figure 26.6) are c. $0.4 \mathrm{~mm}$ apart towards the tip, c. $0.2 \mathrm{~mm}$ apart midspine, and c. $0.4 \mathrm{~mm}$ apart towards the base of the spine. In contrast to the median spines, the height:width ratio increases towards the base, ranging from c. 1.2 to 1.5 . 

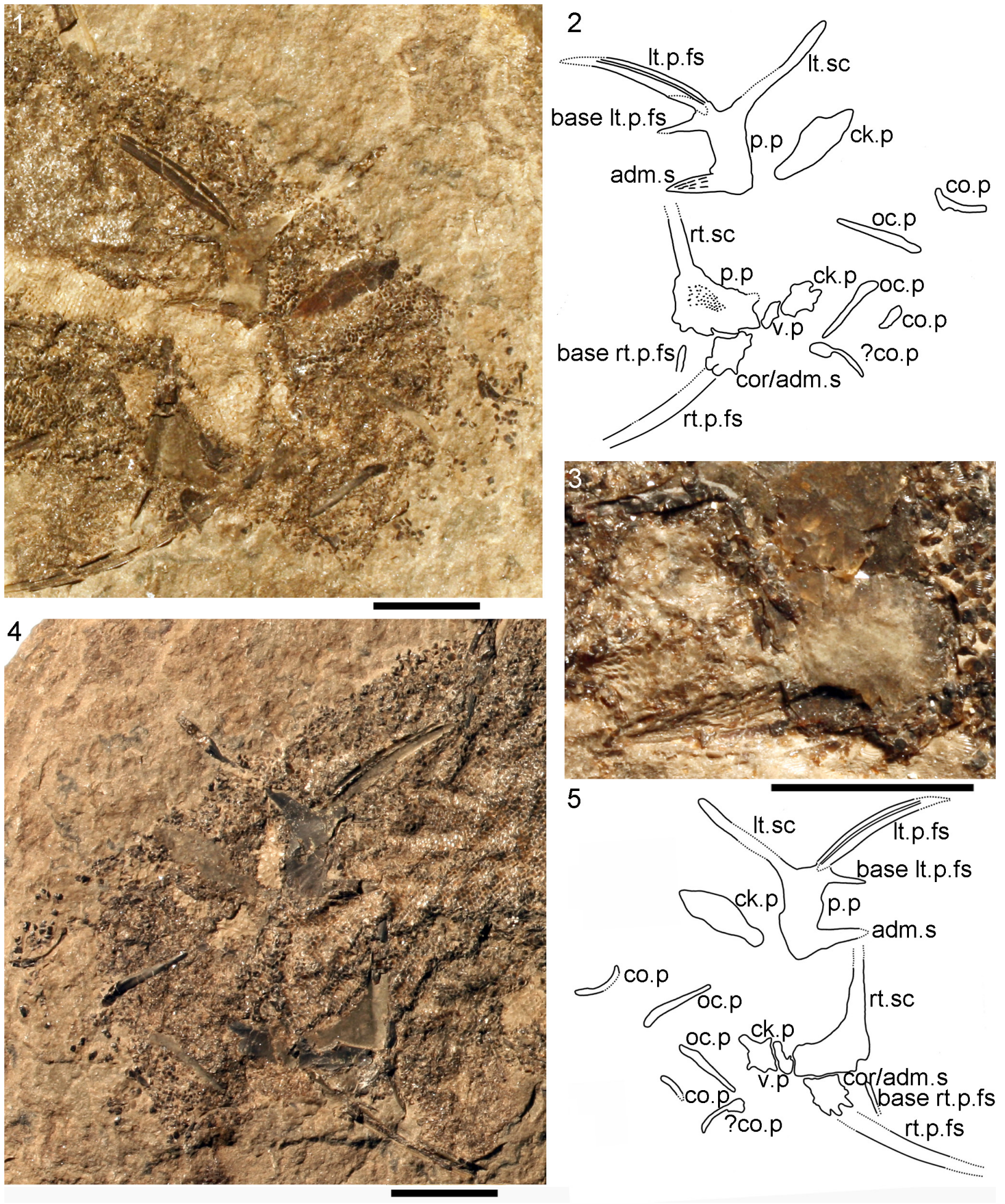

FIGURE 31. Rhadinacanthus longispinus NHM P.4041, from Gamrie, Banffshire, shoulder girdles; 1 , 2, pectoral region and head on the part (anterior to right); 3 , magnified view of the impression of the admedian spine; 4,5 , pectoral region and head on the counterpart (anterior to left). Scale bars equal $1 \mathrm{~cm}$. Abbreviations: adm.s=admedian spine; $c k . p=$ cheek plate; co. $p=$ circumorbital plate; cor/adm. $s=$ coracoid attached to base of admedian spine; It.sc=left scapula; It.p.fs= left pectoral fin spine; oc.p=occlusal plate; $p . p=$ pinnal plate; rt.p.fs=right pectoral fin spine; rt.sc=right scapula; v.p=ventral plate. 


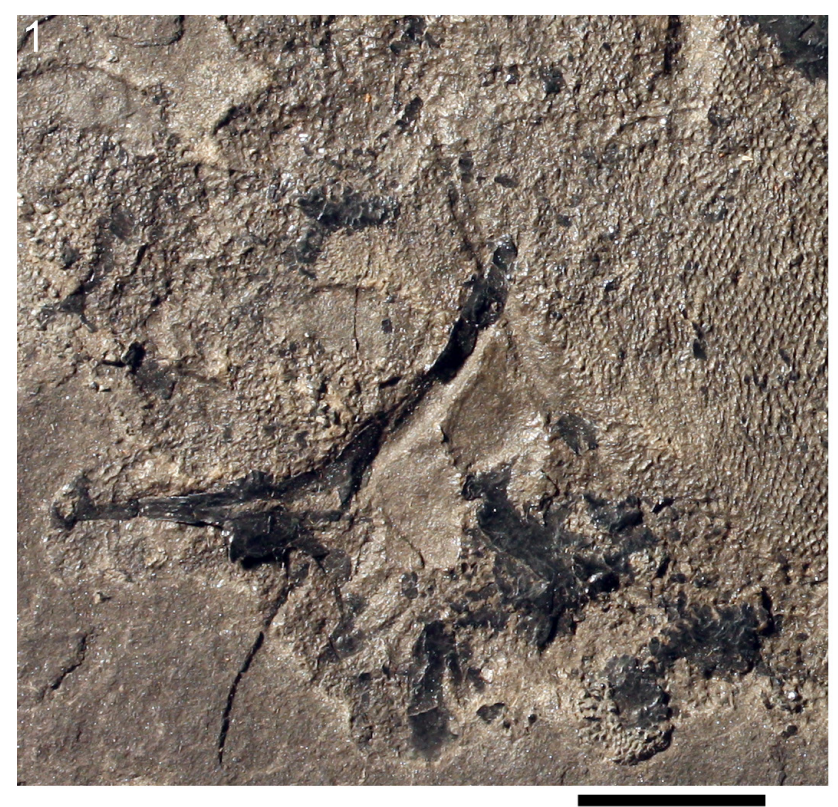

\section{2}
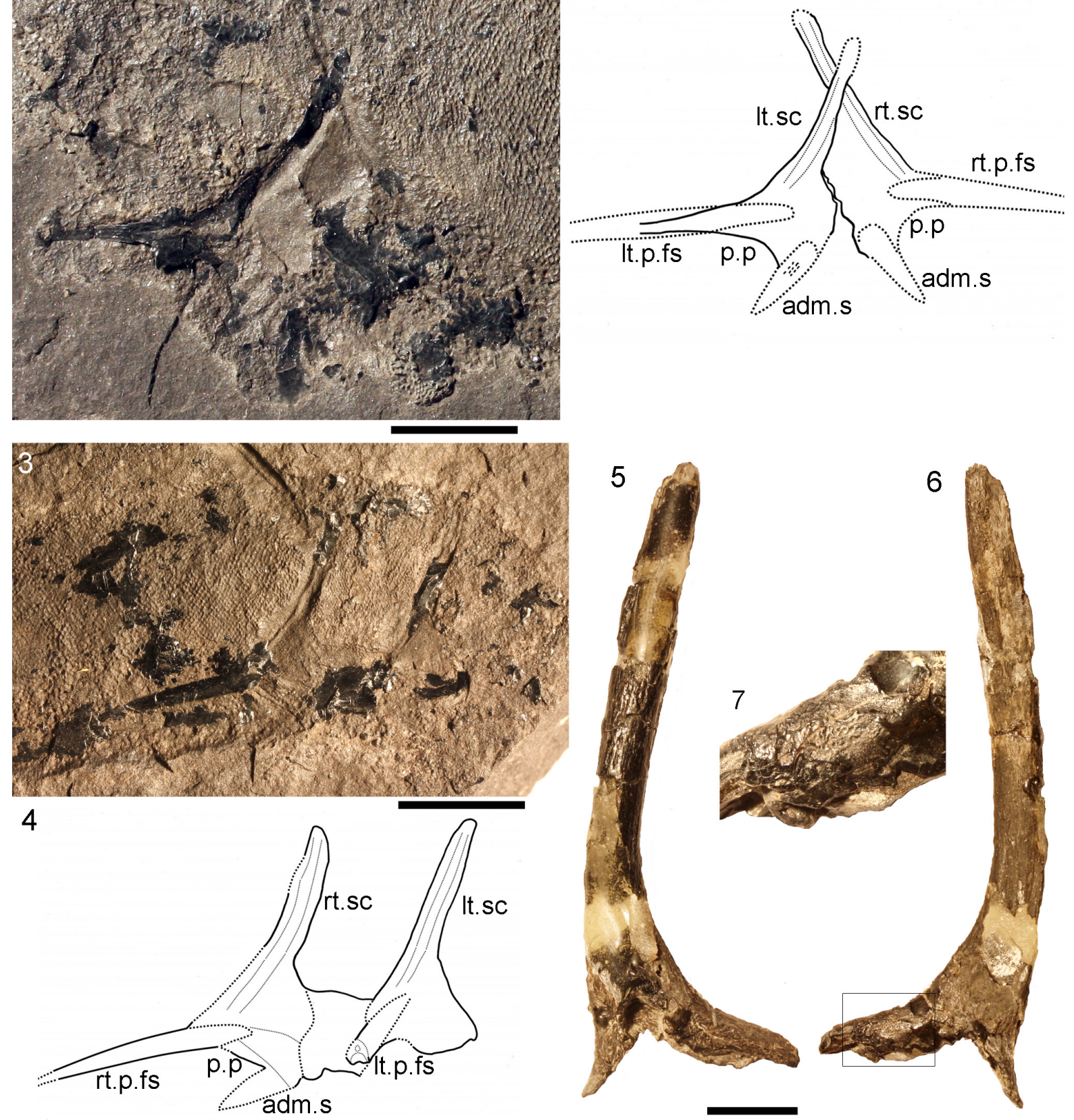

FIGURE 32. Rhadinacanthus longispinus. 1-2, NMS G.1966.49.9 from Orkney, pectoral region and head; 3-4, NMS G.1891.92.334 from Orkney, pectoral region and head; 5-7, isolated scapula NMS G.2014.15.2 from Marwick: 5, ?medial view; 6, ?lateral view, with 7, area with remnants of pinnal plate fused to scapula base. Scale bars equal 1 $\mathrm{cm}$. Abbreviations: adm.s=admedian spine; It.sc=left scapula; It.p.fs= left pectoral fin spine; $p . p=$ pinnal plate; rt.p.fs=right pectoral fin spine; rt.sc=right scapula. 


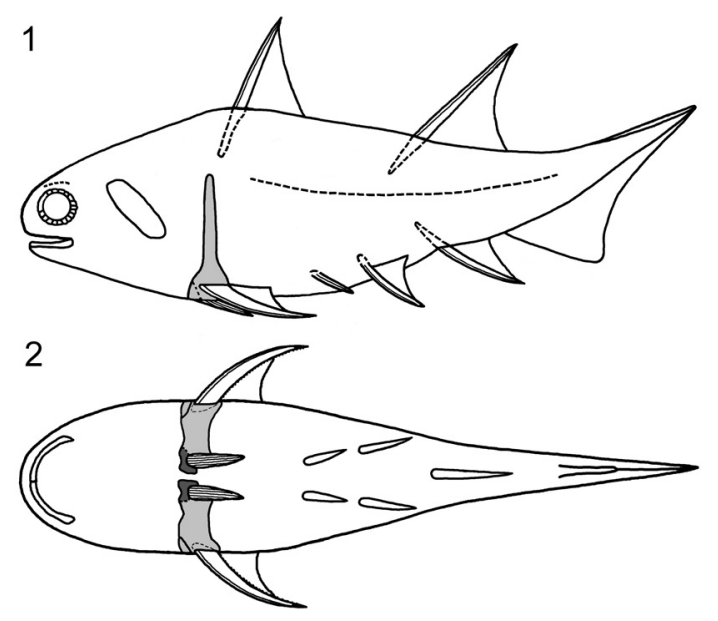

FIGURE 33. Reconstructions of Rhadinacanthus longispinus. 1, lateral view. 2, ventral view. Dark grey fill indicates dermal elements, light grey fill indicates endoskeletal elements.

Histology of the Spines. (Figures 27, 28, 29, 30) All spines have at least one accessory pulp canal (Figures 27.1-2, 27.4, 29). The pectoral and prepelvic spines have two accessory pulp canals, the second and uppermost one in the anterior ridge, although this canal can become infilled (Figure 28.2). In all other spines the only accessory pulp canal is immediately above the main pulp canal. This accessory pulp canal has a small diameter compared with the main canal, and is irregular in shape (Figures 27.1-2, 27.4, 28.2, 29). In cross section, the most conspicuous histological feature is the radial distribution of canals, visible over the whole length of spines including the inserted parts (Figures 27, 28.1-2). In the median spines the initial stage in development of the inserted part consists of trabecular tissue, enclosing vascular canals (Figures 29, 30). The trabecular tissue is separated from the main pulp canal by a thin lining of a dense tissue containing sparsely distributed cell lacunae and processes (Figure 27.2).

The proximal end of the dentinous ornament ridges terminate sharply at the insertion/exsertion boundary, overlying the longitudinal vascular canals encased in narrow osteodenteons which open out on the inserted area. In midspine cross sections, where the main pulp canal is closed, older dentinal ridges remain clearly visible (Figure 27.1-2). Denteons infill vascular canals to a greater extent towards the tip of the spine with the infilling decreasing in thickness proximally (i.e., in the newer spine layers). A denteon only forms in the main pulp canal when it is closed posteriorly (Fig- ure 28.6-7), initially forming along the posterior side of the main pulp canal but rapidly increasing in thickness centripetally towards the spine tip. A translucent tissue covers the dentine ridges (Figure 28.6). The radial arrangement of ridges and vascular canals is found in the median and paired pelvic and pectoral spines, but is only sporadically developed in the prepelvic spines (Figure 28.7). All spines are almost exclusively composed of dentine: trabecular dentine in the initial stages, followed by the radial arrangement of dentinal ridges, covered by a lining of more translucent durodentine, and finally by the development of denteons in vascular and pulp canals. Cell lacunae are only present in the infilling of the main pulp canal.

Shoulder Girdle Complex. (Figures 31, 32, 33) The scapula shaft is high, with the tip often reaching higher than the proximal end of the anterior dorsal spine (Figure 32). The shaft is also slender, flaring out only minimally towards the base (Figures 31,32 ). Fusion of scales on the base of the scapula (Figure 32.7) indicates that the skin was immediately overlying this endoskeletal structure. As in Diplacanthus tenuistriatus, the endoskeletal bone of the scapula, coracoid and procoracoid forms a continuous sheet, with the procoracoid presumed to be the area under the anterior base of the admedian spine (Figure 31.3). Although we have labelled structures as pinnal plates, only the inner endoskeletal bones are exposed on specimens, and it seems possible/likely that scales rather than dermal plates formed their external cover, based on the impressions underlying the endoskeletal bone (Figure 31.3). Presence of a small dermal anterior ventral plate associated with the complex appears variable, as only rarely can one be distinguished (Figure 31).

Morphology of the Scales. (Figures 34, 35) Scale crown ornament shows little variation over the flanks of the fish; scale size decreases from the lateral line towards the dorsal and ventral surfaces and toward the tail (Trinajstic, 2001). There is quite a sharp transition from head tesserae to body scales in front of the scapulocoracoid (Figure 34.1 ), and from normal body scales to small rhombic scales on the fin webs (Figure 34.2). The number of crown ridges varies from 20 or more on larger scales from the central and anterior parts of the body, to about 12 mid-body (Figure 34.3-6), to fewer than 10 on scales from the end of the tail (Figure 34.9). Scales edging the lateral line are markedly larger than the other flank scales (Figure $34.7-8$ ). Scales on the fin webs decrease in size towards the trailing edge of the web (Figure 34.10). 


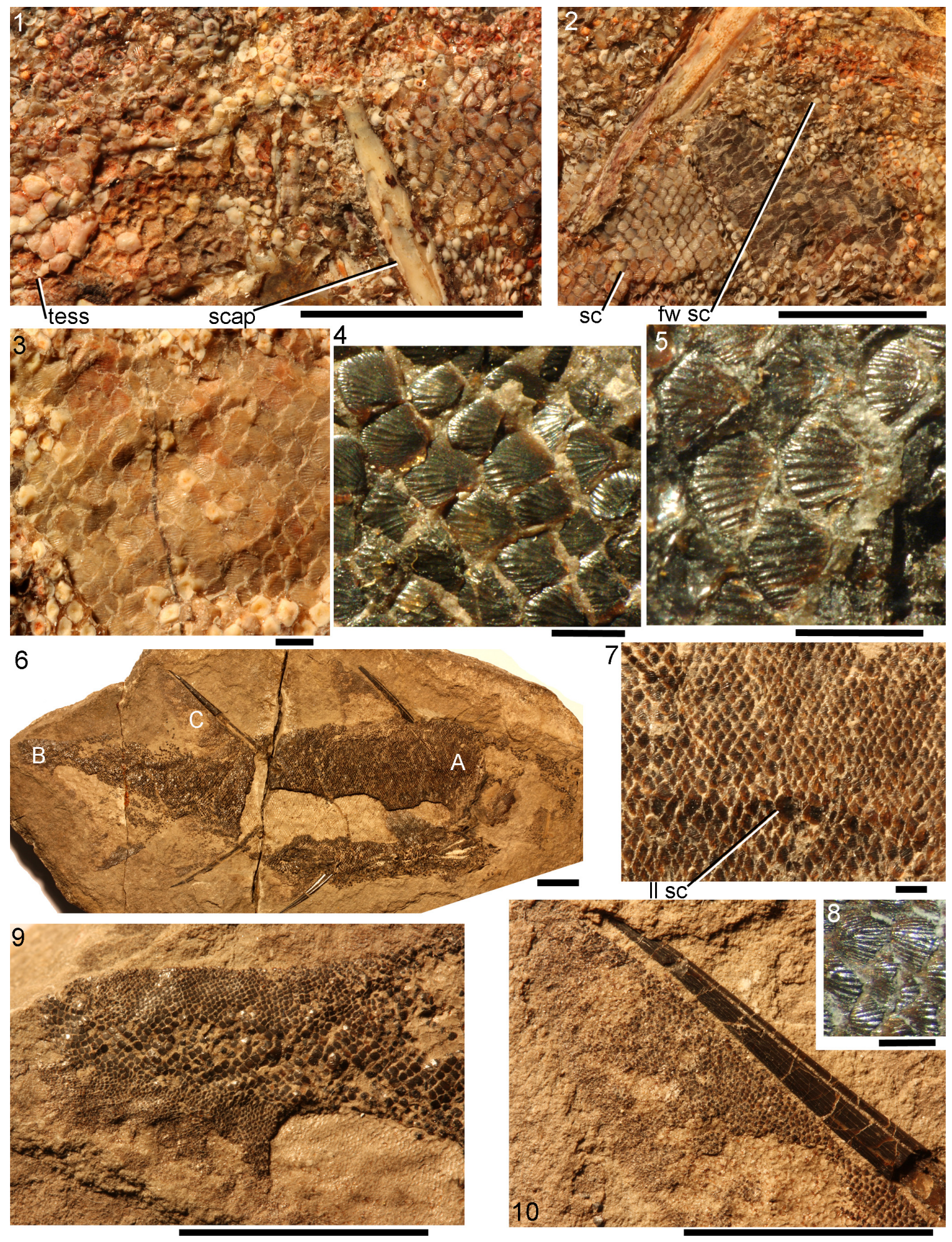

FIGURE 34. Rhadinacanthus longispinus squamation types on different body areas. 1-3, NHM OR.43276 from Tynet Burn, Moray; 1, surrounding scapula shaft; 2, anterior dorsal fin web; 3, mid-flank. 4, NMS G.1892.8.13 from Gamrie, Banffshire, mid-flank; 5, NMS G.2002.59.142pt from Cushnie Burn, Banffshire, mid-flank; 6-10, NHM P.11760 from Gamrie, Banffshire, 6, complete specimen with A, B, C areas magnified in the following images; 7 , midflank with lateral line (area A); 8, below lateral line (area A); 9, tail (area B); 10, posterior dorsal fin web (area C). Scale bars equal $1 \mathrm{~cm}$ in 1-2, 6, 9-10; $1 \mathrm{~mm}$ in 3-5, 7, 8. Abbreviations: fw sc=fin web scales; Il sc=lateral line scales; sc=body scales; scap=scapula shaft, tess=head tesserae. 

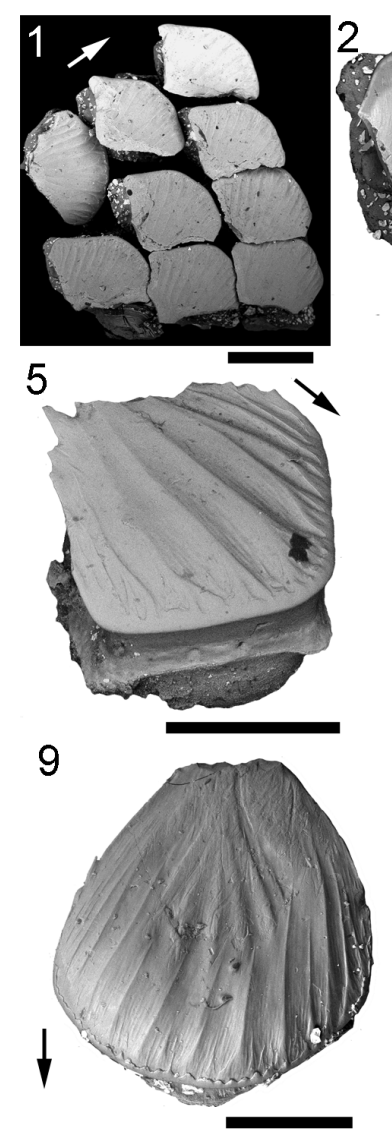

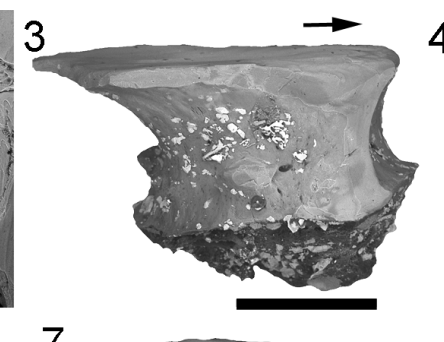

6
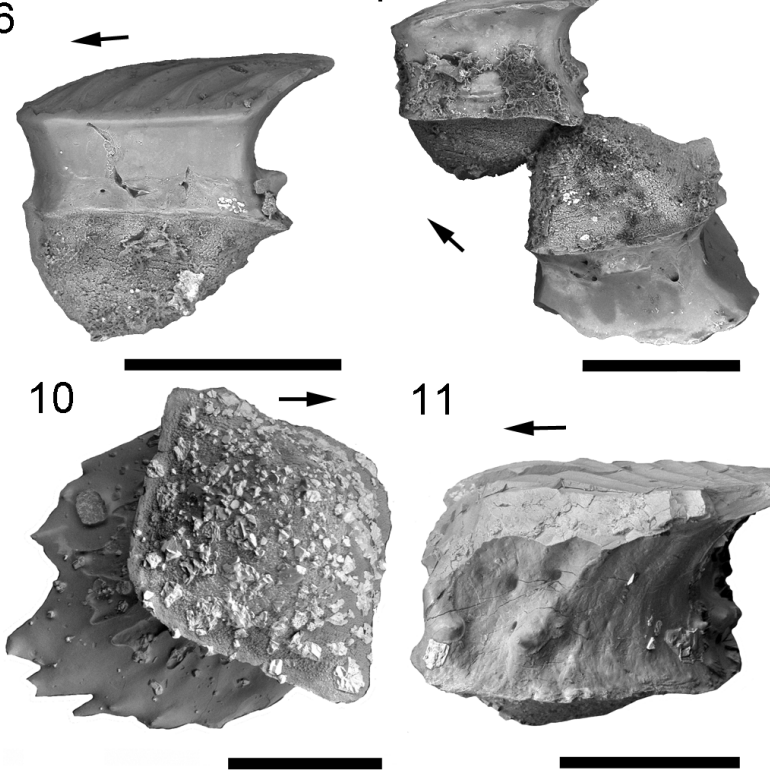

11

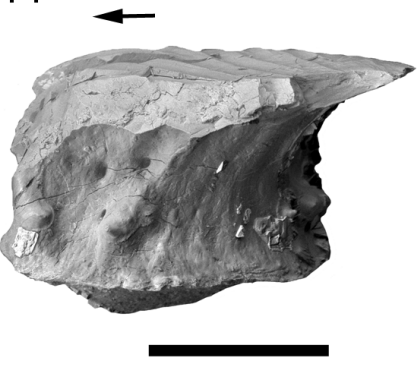

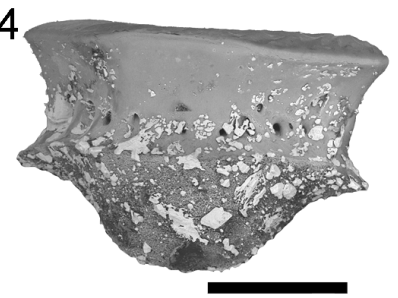

8

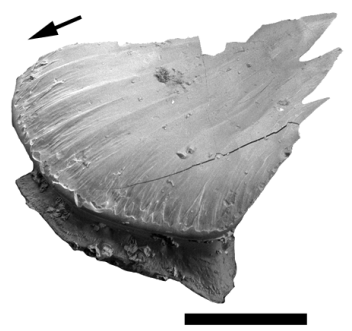

12

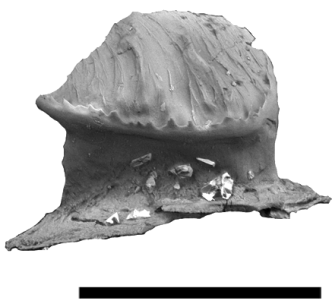

FIGURE 35. Rhadinacanthus longispinus, scanning electron micrographs of scales. 1-4, scales slide NMS G.1892.8.17.1 from Gamrie, Banffshire: 1, 2, crown view of patch of articulated scales, and closeup of scale; 3, lateral view; 4, anterior view. 5-7, scales slide NMS G.1870.14.143.1 from Gamrie, Banffshire: 5, laterocrown view; 6, lateral view; 7, scales from each side of body, stuck together base to base, in posterior view. 8-12, scales slide NMS G.1892.8.15.1 from Gamrie, Banffshire: 8, crown view; 9, crown view; 10, basal view; 11, lateral view; 12, anterior view. Scale bars equal $0.3 \mathrm{~mm}$. White adhesions on scale bases are pyrite crystals. Arrows indicate anterior.

In outline, the flank scales of Rhadinacanthus longispinus (Figures 34.4-5, 35.1) have a broadly rounded anterior margin and rather sharp lateral corners where the anterior margin meets the posterolateral edges at an angle of about $90^{\circ}$. The posterolateral edges are straight or slightly concave and usually denticulated and joining posteriorly in a single sharp point (Figure 35.5, 35.8, 35.10). Scales without serrated posterior margins terminate in an acute angle. Scales are rather uniform in outline, with the crown widest forward of the centre, and width more or less equalling the length. The anterior rim of the crown surface is gently curved and smooth, with a serrated margin overlapping the anterior ends of the ornament ridges (Figure 35.2, 35.8, 35.12). The main ridges often have flattened triangular ends anteriorly, some with multiple branches (Figure 35.5), and sharp crests for the rest of their length, extending back for most or the whole length of the crown. Fine, short ridges are intercalated between the longer ridges in the anterior region of the crown (Figure 35.2, 35.8, 35.9).

The neck of the scales is concave all round. Two rounded swellings occur posteriorly, above the sharp ridge separating the neck from the base, one on either side of the median rib supporting the posterior part of the crown (Figure 35.3, 35.6-7). The base is moderately convex. Scales on the anterior half of the body have subparallel ridges on the crown, and the neck is deeply concave below the strongly denticulated posterior margins (Figure $35.8,35.10)$. The base is oval in outline. In horizontal section, the neck is wider than long with the anterior and posterior faces meeting in sharp points (Figure 35.3, 35.8). Some scales from the 

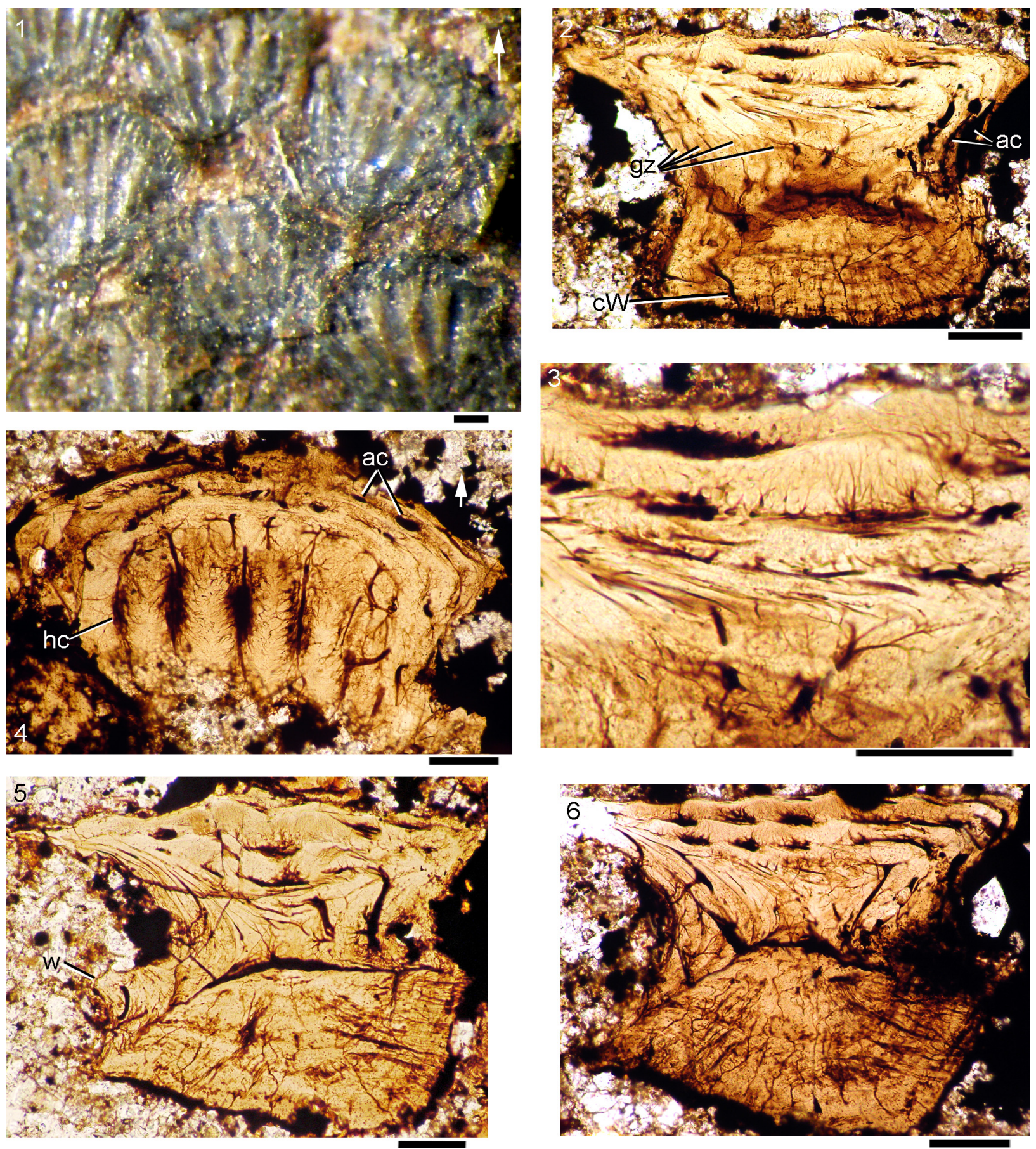

FIGURE 36. Rhadinacanthus longispinus NMS G.2014.4.32 from Achanarras Quarry, Caithness, scale histology. 1, articulated squamation from midflank area; $2-6$, thin sections of midflank scales: 2, oblique vertical section; 3, magnified view of central crown of the same scale; 4, horizontal section of crown; 5 , oblique vertical section; 6 , oblique vertical section. Scale bars equal $0.1 \mathrm{~mm}$. Abbreviations: ac=ascending canal; $\mathrm{cW}=$ canal of Williamson; gz=growth zones; hc=horizontal canal; w=neck swelling. Arrows indicate anterior direction, where relevant. 
area in front of the anterior dorsal spine have very deep necks and flat bases (Figure 35.12), and others have four or more swellings on the neck (Figure 35.11). On the posterior half of the body, scales have only a single posterior point or sparse denticulations along the posterolateral edges. The base of these scales and sections across the neck are subrhombic in outline. Pores to the ascending vascular canals open out in the lower parts of the neck both anteriorly and posteriorly, close to the sharp rim that separates the neck from the base (Figure 35.4).

Histology of the Scales. (Figures 36, 37) Vertical and horizontal thin sections of the scales show the average number of crown growth zones is four (Figures 36.2, 36.4-6, 37.4), the maximum is six or seven (Figure 37.1), and each zone completely covers the older one. The zones are relatively wide. Each growth zone has its own vascular and dentinal canal system. Ascending vascular canals, with an opening to the exterior along the sharp boundary between the neck and the base, parallel to the concave sides of the neck. These canals are often oval in cross section $(20 \mu \mathrm{m}$ by $50 \mu \mathrm{m})$, the long axis of the cross section parallel to the growth lines (Figure 36.4). Near the crown surface they are often connected by narrower horizontal canals with neighbouring ascending canals of the same growth zone (Figure 36.4).

Where the ascending canals reach the crown table they turn horizontally, parallel with the crown surface, and situated underneath the grooves between the crown ridges (Figure 36.4). These horizontal canals have a circular cross section $c$. $20 \mu \mathrm{m}$ diameter; dentine tubules branch off in posterior, lateral, and upward directions (Figures 36.2$6,37)$. The layout of these tubules, extending into the ridges from both sides, was termed "Scheitelung" by Gross (1973) in his description of Rhadinacanthus balticus.

The horizontal canals in the grooves between the ridges are relatively long, extending the whole length of the ridges. Other horizontal canals, formed by ascending canals turning forwards from the posterior side of the scales, are much shorter and arranged more irregularly in the crown table. Dentine tubules in the ridges often anastomose, with lacunal widenings where they interconnect. The dentine of the ridges is more translucent compared with the dentinal tissues elsewhere in the scales but enameloid is not developed. Crown ridges, grooves, and horizontal canals tend to develop over equivalent structures in older growth zones (Figures 36.6, 37.1). Denteons were some- times formed around canals of older growth zones (Figure 37.1, 37.5), although the ascending canals remained open. Short canals run from the neck surface into the neck swellings (Figure 36.5). As the scales grew, new ridges were added along the anterior rim and near the lateral corners.

Growth lines in the crown are continuous with those in the neck and base of the scales (Figure $37.1,37.3-4)$, but growth zones in the base can be obscured by secondary growth lines within each zone. Sharpey's fibres radiate from the base apex. Canals of Williamson are densely developed in some scales (Figure 36), but only sparsely present in others (Figure 37), perhaps reflecting the age of the fish or the different preservation at different localities. Bone cell lacunae are absent.

Remarks. Reconstructions of the whole fish (Figures 33,38 ) show the deeper body profile relative to the other two Scottish species. The two diplacanthids previously referred to as Diplacanthus horridus and $D$. ellsi from the Frasnian Escuminac Formation, Miguasha, Canada, are more closely related to Rhadinacanthus longispinus than to $D$. crassisimus and $D$. tenuistriatus. The Canadian taxa have normal body scales with a few small parallel or converging ridges. In $D$. ellsi, all spines except the admedian and prepelvic ones have two to four grooves on each side; two pulp cavities of which the lower is the larger; posterior face with a central, grooved crest in which, according to Gagnier (1996), the fin web is inserted. Like D. crassisimus and $D$. tenuistriatus, the posterior side of the pectoral spine in $D$. ellsi bears two rows of recurved denticles but contrary to the development in the Scottish Middle Devonian species, these denticles become larger and further apart towards the spine tip. The relatively large scales $(0.25-0.43$ $\mathrm{mm}$ ) in $D$. ellsi, each with about six ridges on the crown, have a high narrow neck and a flat to moderately convex base. In the neck there are two to six large openings. Scales are not overlapping, as the base of the scales is as largeor larger than the crown. In $D$. horridus the fin spines bear only one lateral groove and shallow striae rather than ridges along the sides. The spines show a similar structure to those of $D$. ellsi, with pectoral spines also having the recurved denticles along the posterior side. Some spine fragments (GIT 722-46-1, 2, 3) from the Givetian Burtnieki Stage in the Vezramnieki outcrop, Latvia are identified here as being from $R$. longispinus.

The relatively small flank scales $(0.08-0.14$ $\mathrm{mm}$ wide) have four or five radial or parallel ribs, an antero-posteriorly constricted neck with two large 


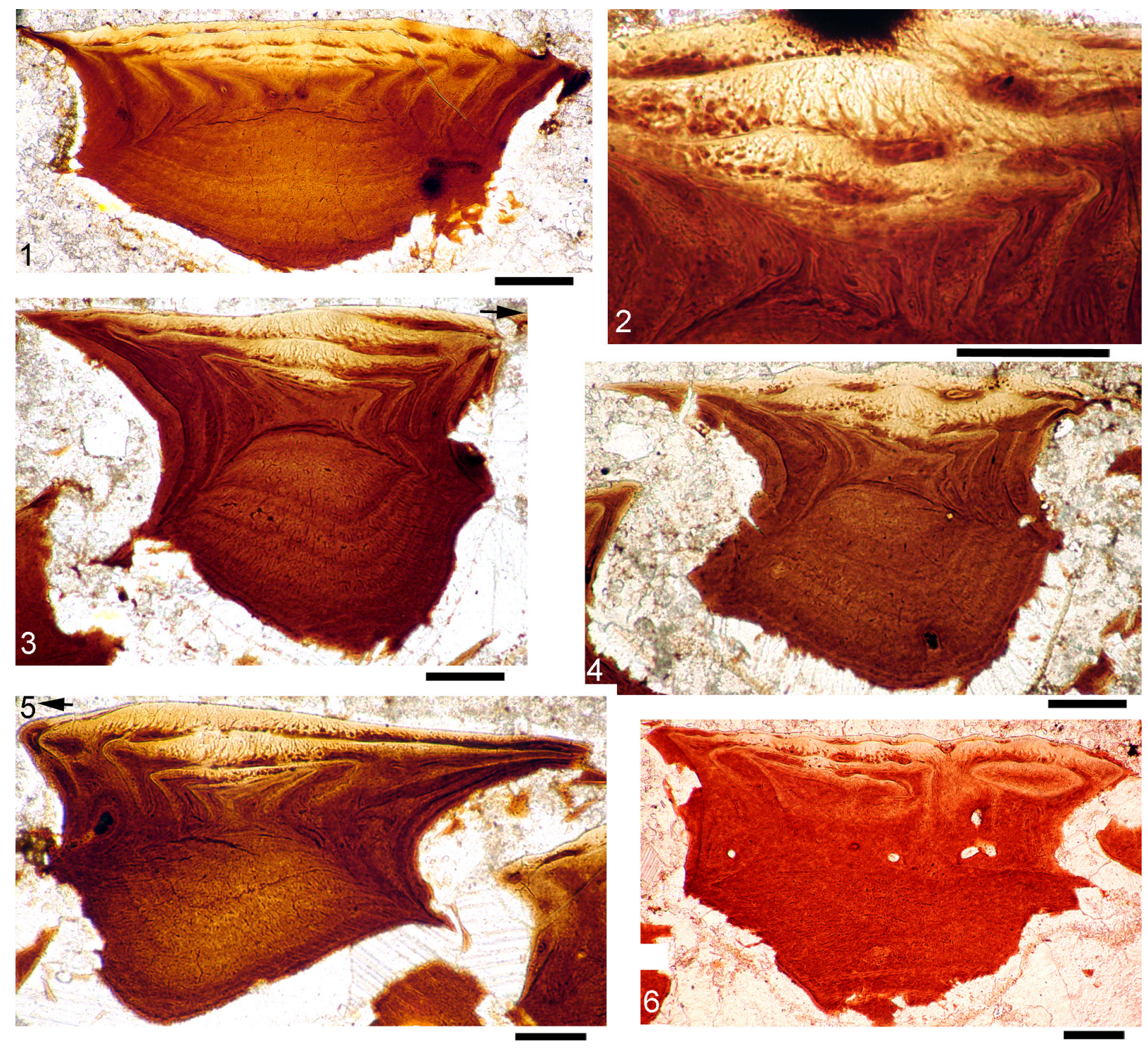

FIGURE 37. Rhadinacanthus longispinus NMS G.2014.44.1 from Cromarty, Ross and Cromarty, scale histology. 1, vertical transverse section; 2 , vertical transverse section; 3 , vertical longitudinal section; 4, oblique vertical section; 5 , vertical section of double scale; 6 , vertical longitudinal section. Scale bars equal $0.1 \mathrm{~mm}$. Arrows indicate anterior direction, where relevant.

foramina anteriorly. Flank scale crowns have a relatively constant morphology over the body, with scales edging the lateral line being larger than neighbouring scales (Trinajstic, 2001), as in Rhadinacanthus longispinus. The main variation is in the extent of the crown ridges, which extend the length of the crown on the anterior flank and only about two-thirds the length of the crown on more posterior scales. Flank scales below the lateral line have a deeper neck and base than those above the lateral line, and caudal scales have a shallower neck and base (Trinajstic, 2001).
The original description of the scales in Rhadinacanthus longispinus Agassiz (1844, p. 43) and the accompanying figures (Agassiz, 1844-1845, plate 14.9) are rather poor. The description of the scales given by Gross (1947) is much better, as he lists a number of important morphological and histological features. Morphologically important features are the delicate forking of the pronounced, sharply crested ribs along the rounded, anterior edge of the larger scales, the densely placed but much smaller ribs on the lateral corner of the scales near the lateral line system, and the denticulated posterolateral edges. Histologically import- 

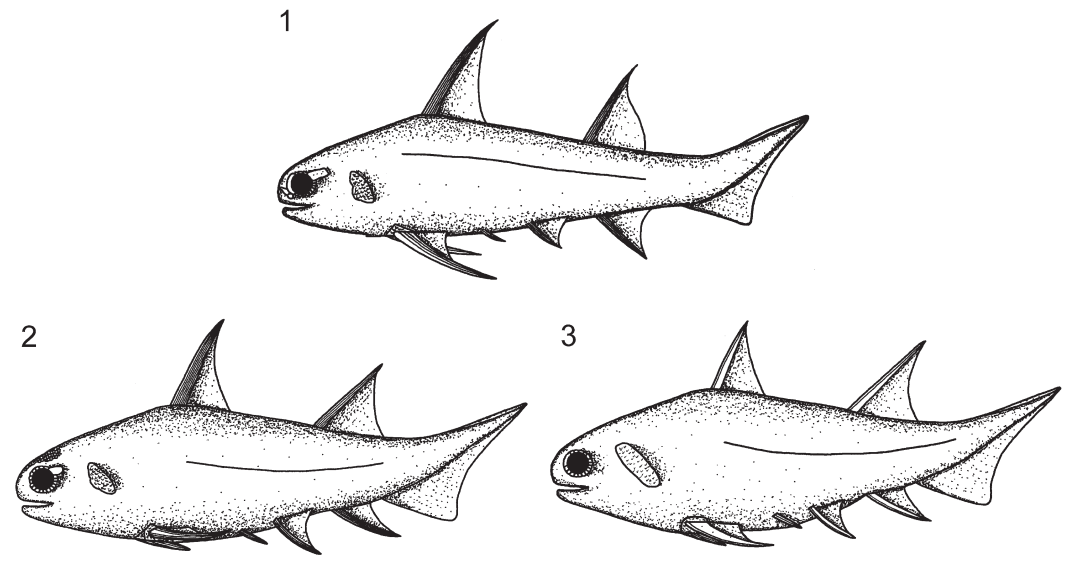

FIGURE 38. 'Life' reconstructions of: 1, Diplacanthus crassisimus, 2, Diplacanthus tenuistriatus, and 3, Rhadinacanthus longispinus.

ant are the relatively wide ascending and horizontal canals and the arrangement of the more delicate dentine tubules, entering the larger ridges from both sides. These features are identically developed both in scales of articulated specimens of $R$. longispinus and in the isolated scales from erratic blocks in northern Germany transported from the Eifelian Narova Beds of the Baltic region that Gross (1973) assigned to Rhadinacanthus balticus. We recognize this species as a junior synonym of $R$. longispinus because of its identical scale morphology and histology.

Valiukevičius (1998) recorded two other species of Rhadinacanthus in the Lower and Middle Devonian of the East Baltic and Byelorussia. Rhadinacanthus primaris Valiukevičius, 1986 (in Valiukevičius and Karatajūtè-Talimaa, 1986), based on isolated scales from upper Emsian to lower Eifelian deposits, is morphologically closely related to scales assigned by Gross and Valiukevičius to $R$. balticus. Although the radial canals are relatively wide, the ascending and horizontal dentinal canals are less wide when compared to the same canals in $R$. longispinus. Delicate dentinal tubules forming the "Scheitelung" of Gross (1973), are apparently not developed in $R$. primaris. Rhadinacanthus multisulcatus Valiukevičius, 1988a encompasses scales from the Givetian and early Frasnian of the Baltic Region and Byelorussia. Plax and Kruchek (2014) also listed $R$. multisulcatus as present in the Goryn Beds (Givetian) in the Pripyat Trough, Belarus. However, the morphology and histology of these scales appear to fit within the range shown by $R$. longispinus, indicating that $R$. multisulcatus is also a junior synonym of $R$. longispinus.

\section{PHYLOGENETIC ANALYSIS}

In recent years, a number of cladistic analyses of gnathostome relationships have been published, including Brazeau (2009), Davis et al. (2012), Zhu et al. (2013), Dupret et al. (2014), and Long et al. (2015). The first two of these papers primarily focussed on redescriptions of the braincase of two acanthodians, Ptomacanthus anglicus Miles, 1973a and Acanthodes bronni Agassiz, 1833, respectively. The latter three publications used the matrix and characters of Davis et al. (2012) as a base, but Zhu et al. (2013) added 115 extra characters and 15 taxa, and Dupret et al. (2014) added two more characters as well as two more placoderm taxa, Romundina and Gavinaspis (not included in our analysis, as our focus is on the acanthodian and not the placoderm relationships). None of the studies revised the codings used by Davis et al. (2012) for acanthodians. The analyses by Brazeau (2009), Davis et al. (2012) showed a paraphyletic Acanthodii, with one group as stem osteichthyans and another as stem chondrichthyans. Zhu et al. (2013) and Long et al. (2015) resolved all acanthodian taxa as stem chondrichthyans, and the analysis by Dupret et al. (2014) showed a monophyletic Chondrichthyes and monophyletic Acanthodii as sister groups. Here we present a new analysis incorporating additional information for acanthodians in the character and coding lists (Appendix 2) and in the data matrix (Appendix 3). Two acanthodians Nerepisacanthus denisoni and Gyracanthides murrayi, representing families Acritolepidae and Gyracanthidae which were not previously included in analyses, have been added to the taxon list. We have performed a basic analysis, but our main aim here is to provide 


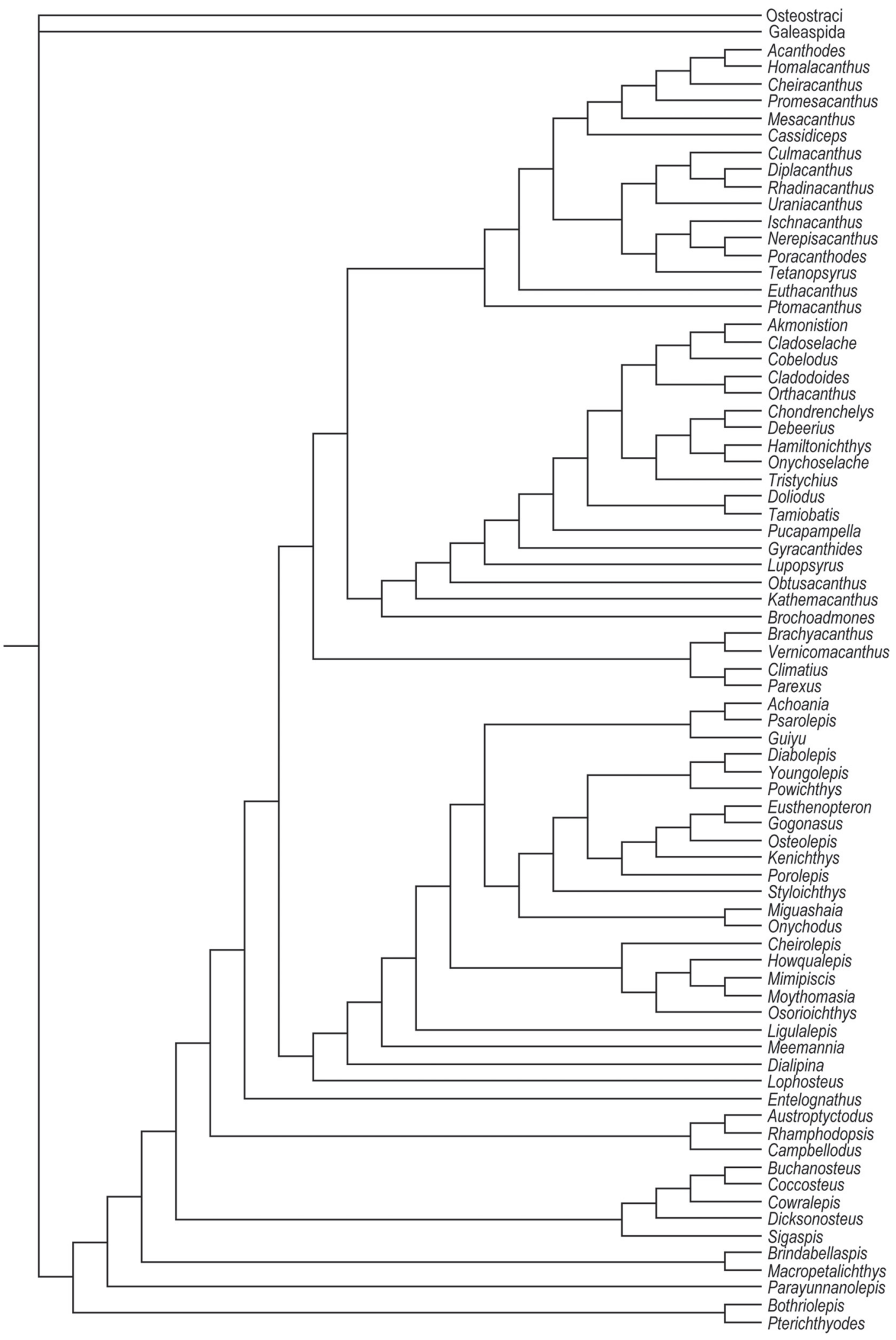

FIGURE 39. Relationship tree generated in phylogenetic analysis of selected early gnathostomes (77 taxa, 262 characters; Tree 1, 641 steps) 
PALAEO-ELECTRONICA.ORG

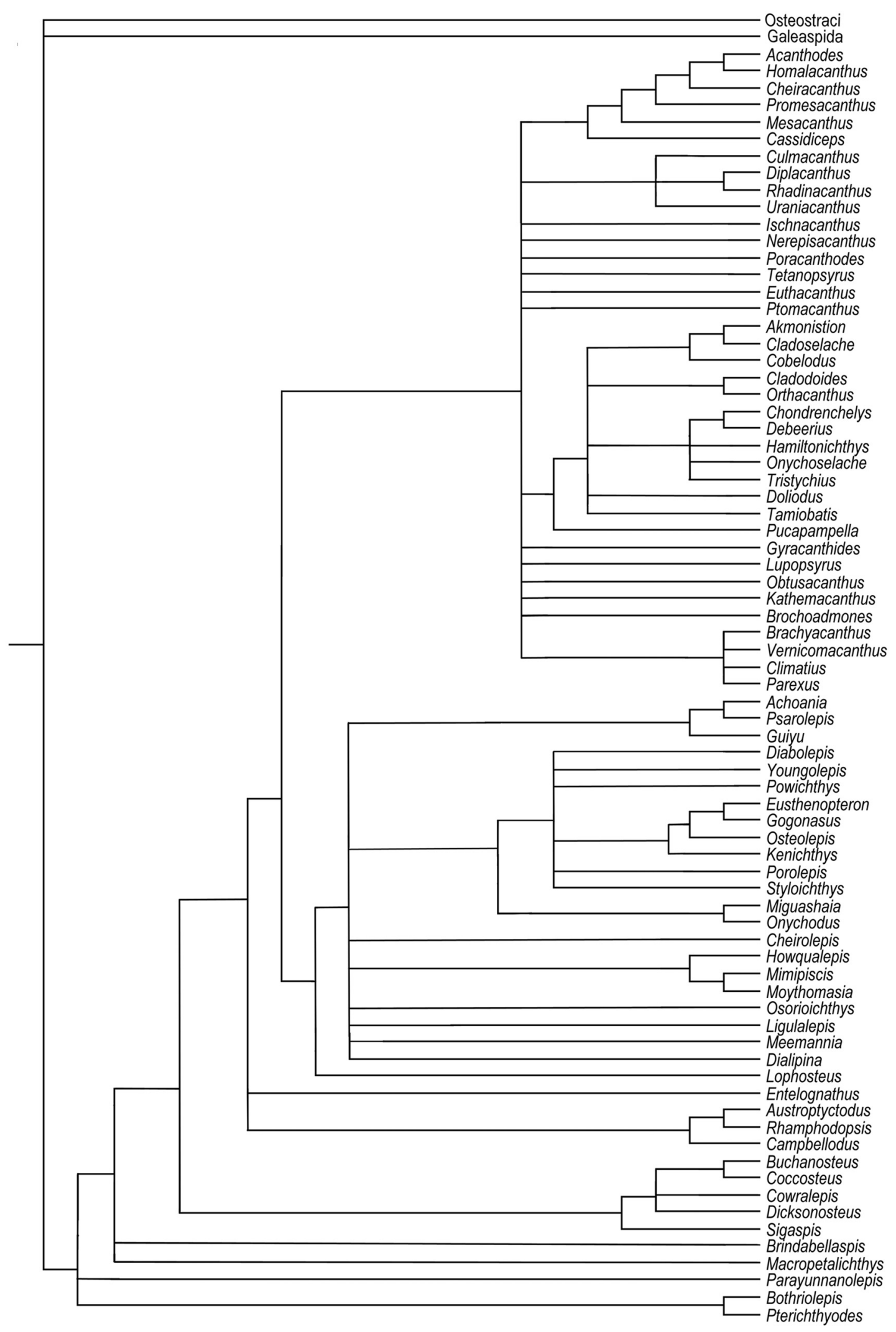

FIGURE 40. Strict consensus relationship tree generated in phylogenetic analysis of selected early gnathostomes (77 taxa, 262 characters). 


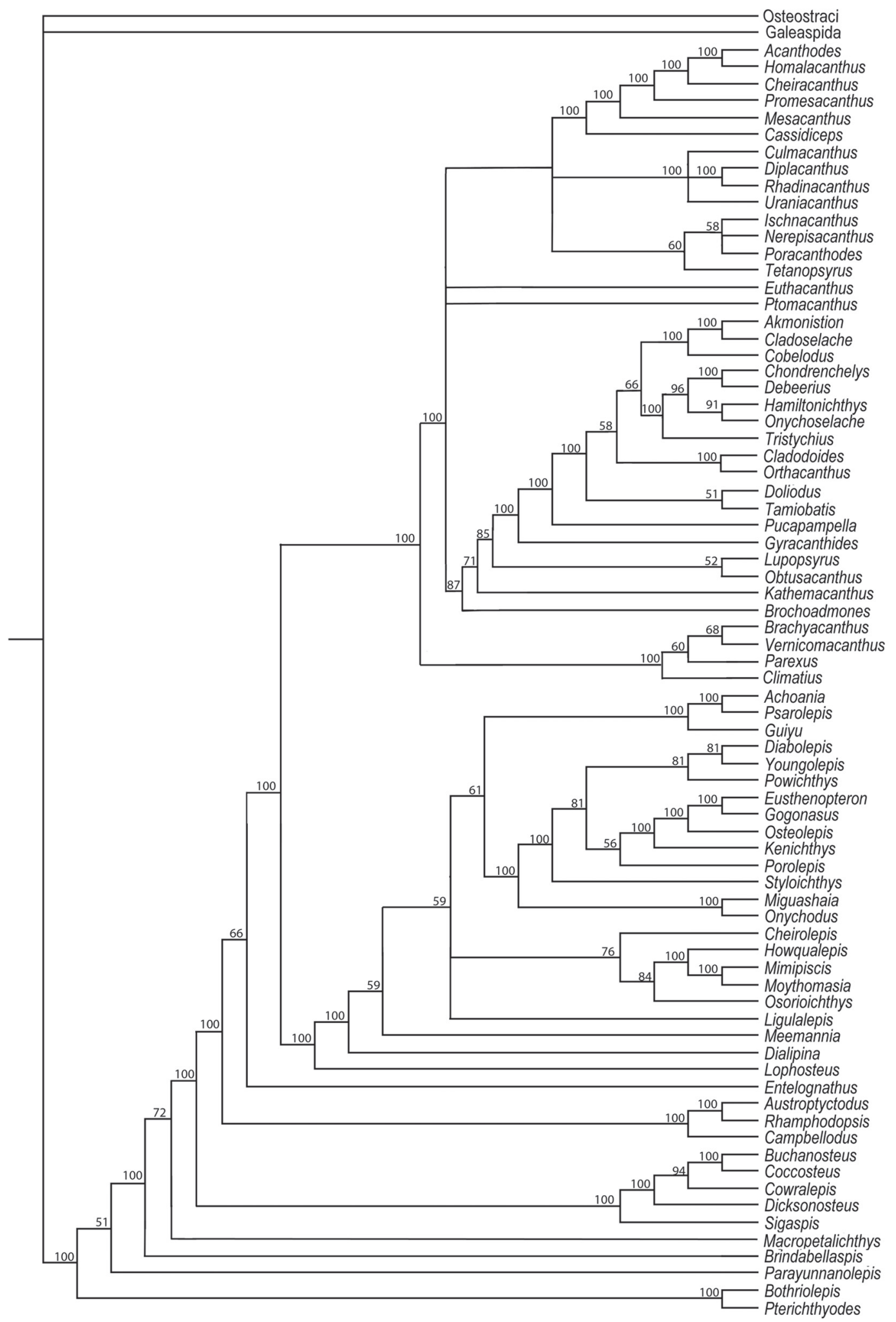

FIGURE 41. 50\% majority rule consensus tree generated in phylogenetic analysis of selected early gnathostomes (77 taxa, 262 characters; numbers on branches show bootstrap support \%). 
the updated and revised data on acanthodians to be incorporated in future analyses by other workers.

A cladistic analysis was run using PAUP 4.0b10 (Swofford, 2002) with the same parameters used by Zhu et al. (2013) in their preliminary run, with Osteostraci and Galeaspida as outgroups. Maxtrees was set at 30000 , nchuck $=1000$, chuckscore $=1$. Shortest tree length was 641 steps. Both strict consensus and $50 \%$ majority rule trees support a topology with acanthodians+chondrichthyans as a clade with $100 \%$ bootstrap support (Figures 39, 40, 41), with chondrichthyans forming a monophyletic group within the clade (also $100 \%$ bootstrap support), paralleling the results of Zhu et al. (2013) and Long et al. (2015). For acanthodians, Acanthodiformes, Diplacanthiformes, and Climatiidae clades are supported in all analyses, with $100 \%$ bootstrap support, and an Ischnacanthiformes clade is supported in our majority rule tree ( $58 \%$ bootstrap support). Perhaps surprisingly, Tetanopsyrus falls outside the Diplacanthiformes, as the sister group to the Ischnacanthiformes, and the Climatiidae is resolved as the sister group to the rest of the acanthodian+chondrichthyan clade $(100 \%$ bootstrap support) in the majority rule tree. The position of the Climatiidae thus differs to that shown in previous analyses, where they are nested within the other acanthodians. The results of our analysis and other analyses since 2012 all provide support for an acanthodian plus chondrichthyan 'supergroup', mirroring the nineteenth century view of acanthodians as 'spiny sharks'.

\section{DISCUSSION}

A number of diplacanthid species described from regions outside of Scotland are considered to be junior synonyms of the Scottish diplacanthid species by the authors (see synonymy lists above). This is not surprising as several placoderms and an osteolepid from Estonia are now known to be conspecific with Scotland taxa (Newman et al., 2015). Our current investigation provides evidence for a number of diplacanthid taxa from the eastern Baltic, Belarus and Severnaya Zemlya which are junior synonyms of Scottish species. Mark-Kurik and Põldvere (2012, figure 3) illustrated the current consensus view on the correlation between Scottish and Estonian vertebrate biostratigraphy through the Middle Devonian. Material here belongs to Diplacanthus crassisimus and includes many spines assigned to Homacanthus gracilis (Eichwald, 1844) and scales assigned to D.? cari- natus Gross, 1973. Some of the spines described as $H$. gracilis by Gross (1940, plate 1, figures 3,4) are from the Tamme Cliffs (Estonia) in the Kureküla Member (middle Givetian), Aruküla Formation where the osteolepid Gyroptychius milleri Jarvik, 1948 is also present (Newman et al., 2015). Diplacanthus crassisimus is also found at the same horizons as G. milleri in Scotland. Other spines from the Tamme Cliffs (Gross, 1940, plate 1, figures 1, 2 ) are here identified as $D$. tenuistriatus, which has a similar range to $D$. crassisimus and $G$. milleri. As in Scotland (Figure 2.2), D. crassisimus has quite a long range in the eastern Baltic, also found in the Eifelian Narva Formation (Valiukevičius 1985, 2003). Märss et al. (2008) also report $D$. carinatus from the Karksi outcrop in the Härma Member, the lowest unit of the Givetian Burtnieki Formation, showing that both spines and scales of $D$. crassisimus occur in the Givetian of the eastern Baltic.

An even wider geographic range for Diplacanthus crassisimus is evidenced by occurrences in Belarus and Severnaya Zemlya. Valiukevičius (2003, figures $20 \mathrm{~K}, \mathrm{~L}$ ) figured scales he assigned to $D$. carinatus from the Vstrechnaya Formation in Severnaya Zemlya, which we have identified as $D$. crassisimus. These deposits are generally regarded as Eifelian perhaps incorporating the lower part of the Givetian. A similar stratigraphic range is probable in Scotland, although the precise position of the Eifelian/Givetian boundary in Scotland is still debated. In Belarus, Plax and Kruchek (2014, plate 3 , figure 15) described scales from a borehole in the Pripyat Trough, which we interpret as scales of $D$. crassisimus. The specimens are from the Goryn and Stolin beds in the Polotsk Regional Stage, considered equivalent to the Aruküla Formation in the eastern Baltic.

Rhadinacanthus balticus Gross, 1973 is here considered a junior synonym of $R$. longispinus. The species was erected by Gross (1973, figures $8 \mathrm{~J}-\mathrm{K}$, 9A-D, plate 28, figures 13-15) for scales from the Eifelian Narva Regional Stage, Estonia. Another species, R. multisulcatus Valiukevičius, 1988, erected for scales from the Eifelian-Givetian Aruküla and Burtnieki formations in the Baltic, Starooskol'sk Formation, Belarus, and the Central Devonian Field, Gorkovskaya region (Valiukevičius (1988a, figure 2, plate 8, figures 9-13) is also considered a junior synonym of $R$. longispinus by the authors. Similarly, scales from a borehole in the Goryn beds, Belarus assigned to R. multisulcatus by Plax and Kruchek (2014, plate 3, figure 17) are now identified as $R$. longispinus. 
The relatively long range of Diplacanthus crassisimus, $D$. tenuistriatus, and Rhadinacanthus longispinus makes specific correlations with individual members and formations across Europe difficult. However, these species show the same chronological range in the Eifelian and early Givetian throughout the northern European occurrences, indicating a close faunal connection between Scotland, the eastern Baltic, Belarus, and Severnaya Zemlya at that time. Middle Devonian diplacanthiform records from further afield are less common, with most apparently being of Culmacanthus (e.g., Burrow and Young, 2012), Rhadinacanthus sp. (e.g., Burrow et al., 2000), and Milesacanthus (Young and Burrow, 2004). Unidentified acanthodian spines and scales have been reported from the Eifelian of Greenland (Blom et al., 2007), but these have not been figured or described.

\section{ACKNOWLEDGEMENTS}

We thank two anonymous reviewers and the editors for suggestions to improve the manuscript. We also thank Z. Johanson, E. Bernard, and V. Young (NHM) for help and access to the collections, and $\mathrm{H}$. Taylor (Image Resources) for the picture of NHM P.1364; J. Clack and M. Lowe (University Museum of Zoology, Cambridge) and M. Carnall (University College London) for information and images of specimens; S. Walsh, R. Paton, and M. Taylor (NMS) for their great help during many visits to the collections and all the help in quickly providing catalogue numbers for specimens donated from this study; and E. Mark-Kurik, U. Toom, and A. Kleesment (GIT) for their help locating Baltic material. We also thank the following individuals: $R$. Jones for lending specimens for study; J. Armstrong for donating a fabulous specimen of Rhadinacanthus longispinus from Achanarras for destructive research (NMS G.2014.4.32); the late $U$. Michie for great help during fieldwork and the many very informative discussions on the geology - without his detailed mapping and great knowledge of the local geology the stratigraphy would still be a riddle; and the late J. Saxon for help and many useful discussions on the fossil fishes from Caithness and Orkney. We also would like to thank J. Cowie from Kirkwall, and A. and M. MacDonald from Thurso for their hospitality during fieldwork, J. and C. Brown from Stromness for the hospitality and many discussions on biostratigraphy, and D. Leather from Westray for the very useful information on the biostratigraphy of Westray.
CJB acknowledges the support of the Queensland Museum in providing facilities.

This is a contribution to IGCP 591: The Early to Middle Paleozoic Revolution, and IGCP 596: Climate change and biodiversity patterns in the MidPaleozoic (Early Devonian to Late Carboniferous).

\section{REFERENCES}

Agassiz, L. 1833-43. Recherches sur les poissons fossiles. Imprimerie de Petitpierre et Prince, Neuchâtel.

Agassiz, L. 1844-45. Monographie de poissons fossiles des Vieux Grès Rouges ou Système Dévonien (Old Red Sandstone) des Îles Britanniques et de Russie. Imprimerie de Petitpierre et Prince, Neuchâtel.

Andrews, S.M. 1982. The discovery of fossil fishes in Scotland up to 1845 with checklists of Agassiz's figured specimens. Royal Scottish Museum, Edinburgh.

Astin, T.R. 1990. The Devonian lacustrine sediments of Orkney, Scotland; implications for climatic cyclicity, basin structure and maturation history. Journal of the Geological Society of London, 147:141-151.

Berg, L.S. 1940. Classification of fishes, both recent and fossil. Trudy Instituta Zoologicheskikh Akademiia Nauk, 5(2):85-517.

Bernacsek, G.M. and Dineley, D.L. 1977. New acanthodians from the Delorme Formation (Lower Devonian) of N.W.T., Canada. Palaeontographica A, 158:1-25.

Blais, S.A., MacKenzie, L.A., and Wilson, M.V.H. 2011. Tooth-Like scales in Early Devonian eugnathostomes and the 'Outside-In' hypothesis for the origins of teeth in vertebrates. Journal of Vertebrate Paleontology, 31:1189-1199.

Blom, H., Clack, J.A., Ahlberg, P.E., and Friedman, M. 2007. Devonian vertebrates from East Greenland: a review of faunal composition and distribution. Geodiversitas, 29:119-141.

Brazeau, M.D. 2009. The braincase and jaws of a Devonian 'acanthodian' and modern gnathostome origins. Nature, 457:305-308.

Brazeau, M.D. 2012. A revision of the anatomy of the Early Devonian jawed vertebrate Ptomacanthus anglicus Miles. Palaeontology, 55:355-367.

Burrow, C.J. 2001. Late Silurian to Middle Devonian acanthodians of eastern Australia. Unpublished Ph D thesis, University of Queensland, Brisbane, Australia.

Burrow, C.J. 2002. Lower Devonian acanthodian faunas and biostratigraphy of south-eastern Australia. Memoirs of the Association of Australasian Palaeontologists, 27:75-137.

Burrow, C.J. 2007. Early Devonian (Emsian) acanthodian faunas of the western USA. Journal of Paleontology, 81:824-840.

Burrow, C.J. 2011. A partial articulated acanthodian from the Silurian of New Brunswick, Canada. Canadian Journal of Earth Sciences, 48(9):1329-1341.

Burrow, C.J., Davidson, R.G., den Blaauwen, J.L., and Newman, M.J. 2015. Revision of Climatius reticulatus Agassiz, 1844 (Acanthodii, Climatiidae), from the 
Lower Devonian of Scotland, based on new histological and morphological data. Journal of Verebrate Paleontology, 35(3): e913421, 15p.

Burrow, C.J., Janvier, P., and Villarroel, C. 2003. Late Devonian acanthodians from Colombia. Journal of South American Earth Sciences, 16:155-161.

Burrow, C.J., Newman, M.J., Davidson, R.G., and den Blaauwen, J.L. 2011. Sclerotic plates or circumorbital bones in early jawed fishes? Palaeontology, 54:207214.

Burrow, C.J., Newman, M.J., Davidson, R.G., and den Blaauwen, J.L. 2013. Redescription of Parexus recurvus, an Early Devonian acanthodian from the Midland Valley of Scotland. Alcheringa: An Australasian Journal of Palaeontology, 37:392-414.

Burrow, C.J. and Rudkin, D. 2014. Oldest near-complete acanthodian: the first vertebrate from the Silurian Bertie Formation Konservat-Lagerstätte, Ontario. PLOS ONE, 9(8):e104171.

Burrow, C.J. and Turner, S. 2010. Reassessment of "Protodus" scoticus from the Early Devonian of Scotland, p. 123-144. In Elliott, D.K., Maisey, J.G., Yu, X., and Miao, D. (eds.), Morphology, Phylogeny and Paleobiogeography of Fossil Fishes. Verlag Dr Friedrich Pfeil, Munich.

Burrow, C.J., Turner, S., and Wang, S.-T. 2000. Devonian microvertebrates from Longmenshan, Sichuan, China: Taxonomic assessment. In Blieck, A. and Turner, S. (eds.), Palaeozoic Vertebrate Biochronology and Global Marine/Non Marine Correlation Final Report IGCP 328, 1991-1996. Courier Forschungsinstitut Senckenberg 223:391-452.

Burrow, C.J. and Young, G.C. 2012. New information on Culmacanthus (Acanthodii: Diplacanthiformes) from the ?Early-Middle Devonian of southeastern Australia. Proceedings of the Linnean Society of New South Wales, 134:21-29.

Chaline, J. 1990. Paleontology of Vertebrates. SpringerVerlag, Berlin.

Clarke, J.M. 1913. Dalhousie and the Gaspe peninsula. Guidebook. Geological Survey of Canada, Ottawa, 1:85-118.

Cloutier, R. and Ahlberg, P.E. 1996. Morphology, characters, and the interrelationships of basal sarcopterygians, p. 445-479. In Stiassny, M.L.J., Parenti, L.R., and Johnson, G.D. (eds. Interrelationships of Fishes. Academic Press, London.

Davidson, R.G. and Trewin, N.H. 2005. Unusual preservation of the internal organs of acanthodian and actinopterygian fish in the Middle Devonian of Scotland. Scottish Journal of Geology, 41:129-134.

Davis, S.P., Finarelli, J.A., and Coates, M.I. 2012. Acanthodes and shark-like conditions in the last common ancestor of modern gnathostomes. Nature, 486:247250.

Dean, B. 1907. Notes on acanthodian sharks. American Journal of Anatomy, 7:209-222.
Dean, B. and Eastman, C. 1916. A Bibliography of Fishes. Volume 2. The American Museum of Natural History, New York.

Denison, R.H. 1979. Acanthodii, p. 62. In Schultze, H.-P. (ed.), Handbook of Paleoichthyology, Part 5. Gustav Fischer Verlag, Stuttgart and New York.

Derycke, C. and Goujet, D. 2011. Multicuspidate shark teeth associated with chondrichthyan and acanthodian scales from the Emsian (Devonian) of southern Algeria. Geodiversitas, 33:209-226.

Dineley, D.L. 1999. Early Devonian fossil fishes sites of Scotland, p. 145-165. In Dineley, D.L. and Metcalf, S.J. (eds.), Fossil Fishes of Great Britain. Joint Nature Conservation Committee Peterborough, UK.

Duff, P. 1842. Sketch of the Geology of Moray. Forsyth and Young, Elgin.

Dupret, V., Sanchez, S., Goujet, D., Tafforeau, P., and Ahlberg, P.E. 2014. A primitive placoderm sheds light on the origin of the jawed vertebrate face. Nature, 507:500-503.

Eastman, C.R. 1907. Devonic fishes of the New York formations. New York State Museum Memoir, 10:1-235.

Eastman, C.R. 1908. Devonian fishes of lowa. lowa Geological Survey Annual Report 1907, 18:29-291.

Eichwald, C.E. 1844. Über die Fische des devonischen systems in der Gegend von Pawlowsk. Bulletin de la Société des Naturalistes de Moscou, 17:824-843.

Eichwald, C.E. 1846. Nachtrag zur der Beschreibung der Fische des Devonisches Systems aus der Gegend von Pawlowsk. Bulletin de la Société Impériale des Naturalistes de Moscou, 19:277-318.

Frickhinger, K.A. 1991. Fossilien-Atlas Fische. Mergus Verlag, Melle.

Gagnier, P.-Y. 1996. Acanthodii, p. 149-164. In Schultze, H.-P. and Cloutier, R. (eds.), Devonian Fishes and Plants of Miguasha, Quebec, Canada. Pfeil, Munich.

Gagnier, P.-Y. and Wilson, M.V.H. 1996. Early Devonian acanthodians from northern Canada. Palaeontology, 39:241-258.

Gardiner, B.G. 1966. Catalogue of Canadian fossil fishes. Contributions to the Royal Ontario Museum, Life Sciences Division, 68:1-154.

Gess, R.W. 2001. A new species of Diplacanthus from the Late Devonian (Famennian) of South Africa. Annales de Paléontologie, 87:49-60.

Goodchild, J.G. 1904. V. The Older Deutozoic Rooks of North Britain. Geological Magazine (Decade V), 1(12):591-602.

Gross, W. 1940. Acanthodier und Placodermen aus den Heterostius-Schichten Estlands und Lettlands. Annals Societatis Rebus Naturae Investigandis in Universitate Tartuensi Constitutae, 46:12-99.

Gross, W. 1942. Die Fischfaunen des baltischen Devons und ihre biostratigraphische Bedeutung. Korrespondenzblatt des Naturforscher-Vereins zu Riga, 64:373436.

Gross, W. 1947. Die Agnathen und Acanthodier des obersilurischen Beyrichienkalks. Palaeontographica A, 96:91-161. 
Gross, W. 1973. Kleinschuppen, Flossenstacheln und Zähne von Fischen aus europäischen und nordamerikanischen Bonebeds des Devons. Palaeontographica $A, 142: 51-155$.

Hamilton, R.F.M. 1987. Comparative Palaeolimology of the Middle Devonian Orcadian Basin. Unpublished $\mathrm{PhD}$ thesis, University of Aberdeen, Aberdeen.

Hamilton, R.F.M. and Trewin, N.H. 1988. Environmental controls on fish faunas of the Middle Devonian Orcadian Basin, p. 589-600. In McMillan, N.J., Embry, A.F., and Glass, D.J. (eds.), Devonian of the World, Vol. III. Canadian Society of Petroleum Geologists Memoirs 14.

Hanke, G.F. 2001. Comparison of an early Devonian acanthodian and putative chondrichthyan assemblage using both isolated and articulated remains from the Mackenzie Mountains, with a cladistic analysis of early gnathostomes. Unpublished PhD Thesis, University of Alberta, Edmonton.

Hanke, G.F. 2008. Promesacanthus eppleri n. gen., n. sp., a mesacanthid (Acanthodii, Acanthodiformes) from the Lower Devonian of northern Canada. Geodiversitas, 30:287-302.

Hanke, G.F. and Davis, S.P. 2008. Redescription of the acanthodian Gladiobranchus probaton Bernacsek \& Dineley, 1977, and comments on diplacanthid relationships. Geodiversitas, 30:303-330.

Hanke, G.F. and Davis, S.P. 2012. A re-examination of Lupopsyrus pygmaeus Bernacsek \& Dineley, 1977 (Pisces, Acanthodii). Geodiversitas, 34:469-487.

Hanke, G.F., Davis, S.P., and Wilson, M.V.H. 2001. New species of the acanthodian genus Tetanopsyrus from northern Canada, and comments on related taxa. Journal of Vertebrate Paleontology, 21:740-753.

Hanke, G.F. and Wilson, M.V.H. 2004. New teleostome fishes and acanthodian systematics, p. 189-216. In Arratia, G., Wilson, M.V.H., and Cloutier, R. (eds.), Recent Advances in the Origin and Early Radiation of Vertebrates. Verlag Dr. Friedrich Pfeil, Munich.

Hanke, G.F. and Wilson, M.V.H. 2006. Anatomy of the early Devonian acanthodian Brochoadmones milesi based on nearly complete body fossils, with comments on the evolution and development of paired fins. Journal of Vertebrate Paleontology, 26:526-537.

Hanke, G.F. and Wilson, M.V.H. 2010. The putative stemgroup chondrichthyans Kathemacanthus and Seretolepis from the Lower Devonian MOTH locality, Mackenzie Mountains, Canada, p. 159-182. In Elliott, D.K., Maisey, J.G., Yu, X., and Miao, D. (eds.), Morphology, Phylogeny and Paleobiogeography of Fossil Fishes. Verlag Dr. Friedrich Pfeil München.

Hay, O.P. 1902. Bibliography and catalogue of the fossil vertebrata of North America. Bulletin of the United States Geological Survey, 179:1-868.

Hay, O.P. 1929. Second bibliography and catalogue of fossil Vertebrata of North America. Publication 390, volume 1. Carnegie Institute of Washington, Washington.
Heyler, D. 1969. Acanthodii, p. 21-70. In Piveteau, J. (ed.), Traité de Paléontologie. Tome IV, vol. 2.

Ivanov, A. and Märss, T. 2014. New data on Karksiodus (Chondrichthyes) from the Main Devonian Field (East European Platform). Estonian Journal of Earth Sciences, 63:156-165.

Jarvik, E. 1948. On the morphology and taxonomy of the Middle Devonian osteolepid fishes of Scotland. Kungliga Svenska Vetenskapsakademiens Handlingar, 25:1-301.

Kleesment, A., Nestor, H., and Soesoo, A. 2006. Devonian in Estonia. GEOGuide Baltoscandia, Tallinn. (In Estonian)

Knell, S.J. and Taylor, M.A. 2006. Hugh Miller: fossils, landscape and literary geology. Proceedings of the Geologists' Association, 117:85-98.

Lambe, L.M. 1905. Progress of Vertebrate Palaeontology in Canada. Proceedings and Transactions of the Royal Society of Canada, Ottawa, (2) 10(4):13-56.

Long, J.A. 1983. A new diplacanthoid acanthodian from the Late Devonian of Victoria. Memoirs of the Association of Australasian Palaeontologists, 1:51-65.

Long, J.A. 1995. The Rise of Fishes. University of New South Wales Press, Sydney.

Long, J.A., Mark-Kurik, E., Johanson, Z., Lee, M.S.Y., Young, G.C., Min, Z., Ahlberg, P.E., Newman, M., Jones, R., Blaauwen, J.d., Choo, B., and Trinajstic, K. 2015. Copulation in antiarch placoderms and the origin of gnathostome internal fertilization. Nature, 517:196-199.

Lyarskaya, L. 1975. New data about acanthodians from the Middle Baltic, p. 227-232. In Grigyalis, A.A. (ed.), Fauna and Stratigraphy of Palaeozoic and Mesozoic of Baltic and Byelorussia. Mintis, Vilnius. (In Russian)

Macfarlane, J.M. 1923. The Evolution and Distribution of Fishes. The Macmillan Company, New York.

Mark-Kurik, E. and Põldvere, A. 2012. Devonian stratigraphy in Estonia: Current state and problems. Estonian Journal of Earth Sciences, 61:33-47.

Märss, T., Kleesment, A., and Niit, M. 2008. Karksilepis parva gen. et sp. nov. (Chondrichthyes) from the Burtnieki Regional Stage, Middle Devonian of Estonia. Estonian Journal of Earth Sciences, 57:219-230.

M'Coy, F. 1848. On some new Ichthyolites from the Scotch Old Red Sandstone. The Annals and Magazine of Natural History, Second Series 11:297-312.

M'Coy, F. 1855. Description of the British Palaeozoic fossils in the Geological Museum of the University of Cambridge. John W. Parker and Son, London.

Miles, R.S. 1966. The acanthodian fishes of the Devonian Plattenkalk of the Paffrath Trough in the Rhineland. Arkiv för Zoologi, 18(9):147-194.

Miles, R.S. 1973a. Articulated acanthodian fishes from the Old Red Sandstone of England, with a review of the structure and evolution of the acanthodian shoulder-girdle. Bulletin of the British Museum (Natural History), Geology, 24:113-213.

Miles, R.S. 1973b. Relationships of acanthodians, p. 63103. In Greenwood, P.H., Miles, R.S., and Patterson, 
C. (eds.), Interrelationships of Fishes. Linnean Society, London.

Miles, R.S. and Westoll, T. S. 1963. Two new genera of Coccosteid Arthrodira from the Middle Old Red Sandstone of Scotland and their stratigraphical distribution. Transactions of the Royal Society of Edinburgh, 65:179-210.

Miller, H. 1841. The Old Red Sandstone (first edition). Thomas Constable and Sons, Edinburgh.

Miller, H. 1847. The Old Red Sandstone(third edition). John Johnstone, Edinburgh.

Miller, H. 1858. Cruise of the Betsey with Rambles of a Geologist. Thomas Constable and Co., Edinburgh.

Moy-Thomas, J.A. and Miles, R.S. 1971. Palaeozoic Fishes. Chapman and Hall, London.

Newman, M.J. 2010. Middle Devonian fish from the Orcadian Basin of Scotland, International Palaeontological Congress 4 pre-conference field trip guide.

Newman, M.J., Burrow, C.J., den Blaauwen, J.L., and Davidson, R.G. 2014. The Early Devonian acanthodian Euthacanthus macnicoli Powrie, 1864 from the Midland Valley of Scotland. Geodiversitas, 36:321348.

Newman, M.J., Davidson, R.G., den Blaauwen, J.G., and Burrow, C.J. 2011. The Early Devonian acanthodian Euthacanthus gracilis from the Midland Valley of Scotland. Scottish Journal of Geology, 47:101-111.

Newman, M.J., Davidson, R.G., den Blaauwen, J.L., and Burrow, C.J. 2012. The Early Devonian acanthodian Uraniacanthus curtus (Powrie, 1870) n. comb. from the Midland Valley of Scotland. Geodiversitas, 34:739-759.

Newman, M.J. and Dean, M.T. 2005. A biostratigraphical framework for geological correlation of the Middle Devonian strata in the Moray-Ness Basin Project area. British Geological Survey Internal Report IR/05/ 160.

Newman, M.J., Mark-Kurik, E., Den Blaauwen, J.L., and Zupiņš, I. 2015. Scottish Middle Devonian fishes in Estonia. Scottish Journal of Geology, 51(2):141-147.

Novitskaya, L.J. and Obruchev, D.V. 1967. Class Acanthodei, p. 263-291 (English translation from Russian). In Obruchev, D.V. (ed.), Fundamentals of Palaeontology Vol. 11. Israel Program for Scientific Translation, Jerusalem.

Owen, R. 1846. Lectures on the comparative anatomy and physiology of the vertebrate animals delivered at the Royal College of Surgeons, England in 1844 and 1846. Part I, Fishes. Longman, Brown, Green and Longmans, London.

Paton, R.L. 1976. A catalogue of fossil vertebrates in the Royal Scottish Museum, Edinburgh. Part Five. Acanthodii. Royal Scottish Museum Information Series, Geology, 6:1-40.

Plax, D.P. 2015. Stratigraphic ichthyofauna assemblages of the Devonian deposits in the east and southeast of Belarus. Lithosphera, 42:20-44.

Plax, D.P. and Kruchek, S.A. 2014. Stratigraphy of Middle Devonian deposits of the western part of the Pri- pyat Trough (according to results of the study of ichthyofauna). Litosphera, 40:24-42.

Poltnig, W. 1984. Fischreste aus dem Unterdevon von Graz (Steiermark). Mitteilungen der naturwissenschafteliche Verreinigung Steiermark, 114:107-131.

Powrie, J. 1864. On the fossiliferous rocks of Forfarshire and their contents. Quarterly Journal of the Geological Society of London, 20:413-429.

Powrie, J. 1870. On the earliest known vestiges of vertebrate life; being a description of the fish remains of the Old Red Sandstone rocks of Forfarshire. Transactions of the Edinburgh Geological Society, 1:284301.

Pradel, A., Maisey, J.G., Tafforeau, P., Mapes, R.H., and Mallatt, J. 2014. A Palaeozoic shark with osteichthyan-like branchial arches. Nature, 509:608-611.

Saxon, J. 1975. The Fossil Fishes of the North of Scotland. Caithness Books, Thurso.

Schultze, H.-P. 1968. Palaeoniscoidea-Schuppen aus dem Unterdevon Australiens und Kanadas und aus dem Mitteldevon Spitsbergens. Bulletin of the British Museum of Natural History (Geology), 16(7):343368.

Smith, B. 1910. Notes on some little-known fishes from the New York Devonian. Proceedings of the Academy of Natural Sciences Philadelphia, 46:656-663.

Sollas, W.J. 1903. A method for the investigation of fossils by serial sections. Philosophical Transactions of the Royal Society (B), 196:259-265.

Swofford, D. 2002. PAUP4.0b10 for Windows. Sinauer Associates, Sunderland, Mass.

Timbs, J. 1859. Curiosities of Science, Past and Present. A Book for Old and Young. Kent and Co., London.

Traquair, R.H. 1888. Notes on the nomenclature of the fishes of the Old Red Sandstone of Great Britain. The Geological Magazine, Decade III, V:507-517.

Traquair, R.H. 1890. On the fossil fishes found at Achanarras Quarry, Caithness. Annals and Magazine of Natural History, 6th series, vol. 9:479-486.

Traquair, R.H. 1892. List of the type and figured specimens in the "Powrie Collection" of fossils. The Annals of Scottish Natural History, 1:31-39.

Traquair, R.H. 1894. On a new species of Diplacanthus, with remarks on the acanthodian shoulder-girdle. Geological Magazine (Decade 4), 1:254-257.

Traquair, R.H. 1895. The extinct animals of the Moray Firth area, p. 235-285. In Harvie Brown, J.A. and Buckley, T.E. (eds.), A Vertebrate Fauna of the Moray Basin. Volume 2. David Douglas, Edinburgh.

Trewin, N.H. 1986. Palaeoecology and sedimentology of the Achanarras fish bed of the Middle Old Red Sandstone, Scotland. Transactions of the Royal Society of Edinburgh, 77:21-46.

Trewin, N.H. and Davidson, R.G. 1999. Lake-level changes, sedimentation and faunas in a Middle Devonian basin-margin fish bed. Journal of the Geological Society, London, 156:535-548.

Trewin, N.H. and Thirlwall, M.F. 2002. Old Red Sandstone, p. 213-249. In Trewin, N.H. (ed.), The Geology 
of Scotland (fourth edition). The Geological Society, London.

Trinajstic, K. 2001. Acanthodian microremains from the Frasnian Gneudna Formation, Western Australia. Records of the Western Australian Museum, Supplement 20:187-198.

Upeniece, I. 2011. Palaeoecology and juvenile individuals of the Devonian placoderm and acanthodian fishes from Lode site, Latvia. Unpublished PhD Thesis, University of Latvia, Riga.

Valiukevičius, J.J. 1985. Acanthodians from the Narva Regional Stage of the Main Devonian Field. Mokslas, Vilnius.

Valiukevičius, J.J. 1988a. New acanthodians from the Middle Devonian of the Baltic and Byelorussia. Palaeontological Journal, 2:80-86.

Valiukevičius, J. 1988b. Correlation of Lower and Middle Devonian deposits of the USSR with acanthodian assemblages. Canadian Society of Petroleum Geologists Memoirs, 14:601-607.

Valiukevičius, J.J. 1992. First articulated Poracanthodes from the Lower Devonian of Severnaya Zemlya, p. 193-214. In Mark-Kurik, E. (ed.), Fossil Fishes as Living Animals. Academy of Sciences of Estonia, Tallinn.

Valiukevičius, J. 1994. Acanthodian zonal sequence of Early and Middle Devonian in the Baltic Basin. Geologija, 17:115-125.

Valiukevičius, J.J. 1998. Acanthodians and zonal stratigraphy of Lower and Middle Devonian in East Baltic and Byelorussia. Palaeontographica A, 248:1-53.

Valiukevičius, J.J. 2000. Acanthodian biostratigraphy and interregional correlations of the Devonian of the Baltic States, Belarus, Ukraine and Russia. Courier Forschungsinstitut Senckenberg, 223:271-289.

Valiukevičius, J. 2002. The acanthodian standard for the Lower and Middle Devonian of the Old Red Sandstone continent, p. 214-218. In Satkunas, J. and Lazauskiene, J. (eds.), The Fifth Baltic Stratigraphical Conference, Vilnius, Lithuania, 22-27 Sept. 2002.

Valiukevičius, J.J. 2003. Devonian acanthodians from Severnaya Zemlya Archipelago (Russia). Geodiversitas, 25(1):131-204.

Valiukevičius, J.J. and Karatajūtè-Talimaa, V.N. 1986. Acanthodian scale assemblage from the base of the Middle Devonian of the Baltic and Byelorussia, p. 110-122 (In Russian). In Brangulis, A.P. (ed.), Biofacies and Fauna of the Silurian and Devonian Basins of the Baltic region. Zinatne, Riga.

Valiukevičius, J.J. and Kruchek, S. 2000. Acanthodian biostratigraphy and interregional correlations of the Devonian of the Baltic States, Belarus, Ukraine and Russia. In Blieck, A. and Turner, S. (eds.), Palaeozoic Vertebrate Biochronology and Global Marine/ Non Marine Correlation, Final Report IGCP 328, 1991-1996. Courier Forschungsinstitut Senckenberg, 223:271-289.

Wandolleck, B. 1900. Pisces für 1894. Archiv für Naturgeschichte, 66:301-367.
Warren, A., Currie, B.P., Burrow, C.J., and Turner, S. 2000. A redescription and reinterpretation of Gyracanthides murrayi Woodward 1906 (Acanthodii, Gyracanthidae) from the Lower Carboniferous of the Mansfield Basin, Victoria, Australia. Journal of Vertebrate Paleontology, 20:225-242.

Waterston, C.D. 1954. Catalogue of type and figured specimens of fossil fishes and amphibians in the Royal Scottish Museum, Edinburgh. Transactions of the Edinburgh Geological Society, 16(1953-4):i-x, 191.

Watson, D.M.S. 1937. The acanthodian fishes. Philosophical Transactions of the Royal Society (B), 228:49-146.

Westoll, T.S. 1937. The Old Red Sandstone fishes of the North of Scotland, particularly of Orkney and Shetland. Proceedings of the Geologists Association, 48:13-45.

Whiteaves, J.F. 1881. On some remarkable fossil fishes from the Devonian rocks of Scaumenac Bay, Province of Quebec. Annals and Magazine of Natural History 5th series, vol. 8:159-162.

Whiteaves, J.F. 1889. Illustrations of the fossil fishes of the Devonian rocks of Canada. Part II. Transactions of the Royal Society of Canada, 6(iv):77-96.

Woodward, A.S. 1891. Catalogue of the fossil fishes in the British Museum (Natural History). Part II. British Museum (Natural History).

Woodward, A.S. 1892. Further contributions to knowledge of the Devonian fishes of Canada. The Geological Magazine, 9 (new series. Decade III):481-485.

Woodward, A.S. 1906. On a Carboniferous fish fauna from the Mansfield district, Victoria. Memoirs of the National Museum, Melbourne, 1:1-32.

Wundsch, H.H. 1912. Pisces für 1911. Archiv für Naturgeschichte, 78(4):225 p.

Young, V.T. 1995. Micro-remains from Early and Middle Devonian acanthodian fishes from the U.K. and their biostratigraphic possibilities. Ichthyolith Issues Special Publication, 1:65-68.

Young, V.T. 1997. Early Palaeozoic acanthodians in the collection of the Natural History Museum, London. Ichthyolith Issues Special Publication, 3:46-50.

Young, G.C. and Burrow, C.J. 2004. Diplacanthid acanthodians from the Aztec Siltstone (late Middle Devonian) of southern Victoria Land, Antarctica. Fossils and Strata, 50:23-43.

Zhu, M., Yu, X., and Ahlberg, P.E. 2001. A primitive sarcopterygian fish with an eyestalk. Nature, 410:81-84.

Zhu, M., Yu, X., Ahlberg, P.E., Choo, B., Lu, J., Qiao, T., Qu, Q., Zhao, W., Jia, L., Blom, H., and Zhu, Y.A. 2013. A Silurian placoderm with osteichthyan-like marginal jaw bones. Nature, 502:188-193.

Zhu, M., Zhao, W., Jia, L., Lu, J., Qiao, T., and Qu, Q. 2009. The oldest articulated osteichthyan reveals mosaic gnathostome characters. Nature, 458:46974. 


\section{APPENDIX 1}

Specimen registration numbers with lists of thin section numbers derived from them, showing the relevant Figure numbers.

NMS G.2014.33.10, Diplacanthus crassisimus from Corbie Den, Banffshire.

Figures 5.6, 12.1-4, NMS G.2014.33.10.2

Figure 12.5-7, NMS G.2014.33.10.1

NMS G.2014.33.9, Diplacanthus crassisimus from Corbie Den, Banffshire.

Figure 5.7, NMS G.2.14.33.9.1

NMS G.2014.44.2, Diplacanthus crassisimus from Corbie Den, Banffshire.

Figures 5.9, 8.10, NMS G.2014.44.2.1

NMS G.2014.33.8, Diplacanthus crassisimus from west of Castletown harbour, Caithness.

Figure 8.1, NMS G.2014.33.8.2

Figure 8.2, NMS G.2014.33.8.3

Figure 9.2, NMS G.2014.33.8.1-6

NMS G.2015.11.2, Diplacanthus crassisimus from Gamrie, Banffshire.

Figure 8.3-5, NMS G.2015.11.2.16

NMS G.2015.11.3, Diplacanthus crassisimus from Gamrie, Banffshire.

Figure 12.8-9, NMS G.2015.11.3.2

NMS G.2015.11.2, Diplacanthus crassisimus from Gamrie, Banffshire.

Figure 12.10, NMS G.2015.11.2.21

Figure 12.11, NMS G.2015.11.2.6

NMS G.2014.4.18, Diplacanthus tenuistriatus from Marwick, Orkney.

Figure 16.5-6, NMS G.2014.4.18.2

NMS G.2014.33.1, Diplacanthus tenuistriatus from North Ronaldsay, Orkney.

Figure 16.7, NMS G.2014.33.1.2

NMS G.2014.7.36, Diplacanthus tenuistriatus from Marwick, Orkney.

Figures 16.1-4, 17.1, NMS G.2014.7.36.1

Fig. 17.2, NMS G.2014.7.36.2

NMS G.2014.7.35, Diplacanthus tenuistriatus from Marwick, Orkney.

Figures 16.5-6, 17.3, NMS G.2014.7.35.1

Figure 17.4, NMS G.2014.7.35.2

NMS G.2014.4.20, Diplacanthus tenuistriatus from Marwick, Orkney.

Figures 18.6, 19, J2B

Figures 18.7-8, 19, J2A

Figures 18.9, 19, J2

Figure 19, 12

NMS G.2014.4.27, Diplacanthus tenuistriatus from Flashes, Hoy, Orkney.

Figure 18.1-11, D2

Figure 19, A2-F1, I1
NMS G.2014.4.23, Diplacanthus tenuistriatus from Marwick, Orkney.

Figure 19, 10A, 10B

NMS G.2014.20.20, Diplacanthus tenuistriatus from Marwick, Orkney.

Figure 20, K2, L2, M2, O1

NMS G.1897.55.1, Diplacanthus tenuistriatus from Achanarras Quarry, Caithness.

Figure 21.4-5, NMS G.1897.55.1.2

Figure 21.6-7, NMS G.1897.55.1.5

Figure 21.8, NMS G.1897.55.1.3

Figure 21.9, NMS G.1897.55.1.8

NMS G. Canon Kyle no.1 Diplacanthus tenuistriatus from Tynet Burn, Moray.

Figure 22.4, NMS G.Canon Kyle no. 1.2

Figure 22.5, NMS G.Canon Kyle no. 1.5

Figure 22.6-8, NMS G.Canon Kyle no. 1.11

NMS G.1892.8.9, Diplacanthus tenuistriatus from Gamrie, Banffshire.

Figure 22.10, NMS G.1892.8.9.15

Figure 22.11, NMS G.1892.8.9.13

Figure 22.12, NMS G.1892.8.9.6

Figure 22.13, NMS G.1892.8.9.4

Figure 22.14, NMS G.1892.8.9.6

Figure 22.15, NMS G.1892.8.9.5

Figure 22.16, NMS G.1892.8.9.7

NMS G.2015.11.1, Rhadinacanthus longispinus from Broad Taing, Orkney.

Figures 27.1-2, 30.4, NMS G.2015.11.1.3

NMS G.2014.4.33, Rhadinacanthus longispinus from the slates west of East Murkle Bay, Caithness.

Figure 27.3, NMS G.2014.4.33.2

Figure 27.4-5, NMS G.2014.4.33.4

Figure 30.1-2, NMS G.2014.4.33.1-8

NMS G.2014.33.2, Rhadinacanthus longispinus median spine from North Ronaldsay.

Figure 27.6, NMS G.2014.33.2.2

NMS G.2014.4.32, Rhadinacanthus longispinus from Achanarras Quarry, Caithness.

Figure 28.1, NMS G.2014.4.32.13

Figure 28.2, NMS G.2014.4.32.11

Figure 28.3-4, NMS G.2014.4.32.21

Figure 28.5, NMS G.2014.4.32.24

NMS G.2014.44.1, Rhadinacanthus longispinus from Cromarty, Ross and Cromarty.

Figure 28.6-7, NMS G.2014.44.1.16

NMS G.2014.33.2, Rhadinacanthus longispinus from the slates west of East Murkle Bay, Caithness. 
Figure 30.3, NMS G.2014.33.2.2

NMS G.2014.44.1, Rhadinacanthus longispinus from Cromarty, Ross and Cromarty.

Figure 37.1, NMS G.2014.44.1.4
Figure 37.2, NMS G.2014.44.1.9

Figure 37.3-4, NMS G.2014.44.1.6

Figure 37.5, NMS G.2014.44.1.5

Figure 37.6, NMS G.2014.44.1.7 


\section{APPENDIX 2.}

Characters 1-253 are adopted from Zhu et al. (2013). Changes to characters have been written in boldface type. Characters 254, 255 are extra characters added by Dupret et al. (2014). Characters 256-262 are newly added characters.

Changes to codings in the data matrix from Zhu et al. (2013) have been highlighted in blue in the new data matrix (Appendix 3); the red highlighting used by Zhu et al. (2013) to show their coding changes has also been retained. Many of the unknown (?) codings in their analysis have been corrected to inapplicable (-), even though it is understood that codings (-) and (?) are treated equally in the phylogenetic analysis.

Character codings have been added or changed based on photographs of all acanthodian specimens in the National Museums Scotland and the ?stem chondrichthyan Doliodus in the New Brunswick Museum (BNHM) collections, and our work on the Lower and Middle Devonian acanthodians of Scotland, as well as the following publications for specified taxa:

Brochoadmones: Hanke and Wilson (2006);

Cassidiceps: Gagnier and Wilson (1996);

Climatius: Burrow et al. (2015);

Culmacanthus: Long (1983), Burrow and Young (2012);

Diplacanthus: Gross (1947: type species Diplacanthus crassisimus, referred by Gross to $D$. striatus, a junior synonym), Young (1995);

Euthacanthus: Newman et al. (2011, 2014);

Gladiobranchus = Uraniacanthus - previous analyses included the acanthodian Gladiobranchus in the taxon list, but Newman et al. (2012) demonstrated that G. probaton should be reassigned to Uraniacanthus, by priority: Hanke and Davis (2008), Newman et al. (2012);

Kathemacanthus: Hanke and Wilson (2010);

Lupopsyrus: Hanke and Davis (2012);

Nerepisacanthus: Burrow (2011), Burrow and Rudkin (2014);

Obtusacanthus: Hanke and Wilson (2004);

Parexus: Burrow et al. (2013);

Ptomacanthus: Brazeau (2012);

Rhadinacanthus: Gross (1947: R. longispinus was referred by Gross to Diplacanthus), Young (1995);

Tetanopsyrus: Hanke et al. (2001);

All MOTH acanthodian taxa: Hanke (2001);

Various acanthodian taxa: Miles (1966, 1973a, b), Watson (1937), and Burrow et al. (2011).

1. Tessellate calcified cartilage: absent (0); present (1).

This character was previously specified tessellate prismatic calcified cartilage, but histological study has been made of very few mid-Palaeozoic taxa, hence we have omitted 'prismatic' from the character. Doliodus should be coded as (?), because the calcified cartilage resembles the irregularly patterned calcified cartilage in acanthodians, rather than the regular tessellate pattern of polygonal tesserae in Late Devonian and younger chondrichthyans.

2. Perichondral bone: present (0); absent (1).

3. Extensive endochondral ossification: absent (0); present (1).

4. Dentine: absent (0); present (1).

Of the two outgroups, galeaspids lack dentine, whereas osteostracans have dentine. Earliest representatives of all gnathostome groups for which histological structure is known, have dentine, even though younger taxa can lack this tis- sue (e.g. the Early Devonian antiarch Parayunnanolepis vs. Late Devonian Bothriolepis). However, we have kept the polarity used in previous studies but note that we are not convinced that $(0)$ represents the general condition. Codings for several taxa are changed from (?) to (1): studies in progress on the Old Red Sandstone acanthodians of Scotland show that Brachyacanthus, Ischnacanthus, Mesacanthus and Rhadinacanthus scales are dentinous (CJB pers. obs.); Hanke (2001, fig. 130) figured Cassidiceps scale structure; eroded scales of Culmacanthus (Long 1983) show the dentinous structure of the crown; Schultze (1968) illustrated the dentinous histology of Dialipina; Both Doliodus teeth and scales are dentinous (BNHM collection, CJB pers. obs.); Hanke and Davis (2012, fig. 6G) figured Lupopsyrus scale structure; Burrow et al. (2013, fig. 13) figured Parexus scale structure; Brazeau (2012, fig. 7) figured Ptomacanthus scale structure.

5. Type of dentine: mesodentine (0); semidentine (1); orthodentine (2). 
Codings for several taxa have been changed from previous matrices: studies in progress on the Old Red Sandstone acanthodians of Scotland show that Brachyacanthus and Diplacanthus and Rhadinacanthus have mesodentine; Uraniacanthus has mesodentine, cf. Hanke and Davis (2008, fig. 13); Ischnacanthus and Mesacanthus scales have orthodentine (CJB pers. obs.); Lupopsyrus scales have Stranggewebe, a form of mesodentine, cf. Hanke and Davis (2012); Obtusacanthus has mesodentine including Stranggewebe (Hanke and Wilson 2004, fig. 10); Parexus teeth have mesodentine (Burrow et al. 2013); Promesacanthus scales have orthodentine (Hanke 2008, fig. 7); Ptomacanthus scales have mesodentine including Stranggewebe, cf. Brazeau (2012);

6. Cosmine: absent (0); present (1).

7. Lepidotrichia or lepidotrichia-like scale alignment: present (0); absent (1).

Fin webs preserved on specimens of Parexus and Rhadinacanthus in the NMS collection show this type of scale alignment.

8. Body scale growth pattern: monodontode (0); polyodontode (1).

Brachyacanthus, Climatius, Ischnacanthus, Mesacanthus and Rhadinacanthus scales are polyodontode (Burrow et al., 2015; this paper; CJB pers. obs.); eroded Culmacanthus scales show superposed growth zones (Long, 1983).

9. Body scale growth concentric: absent (0); present (1).

Brachyacanthus and Climatius scales show areal growth and so are coded (0), Ischnacanthus, Mesacanthus and Rhadinacanthus show superposed growth (this paper, CJB pers. obs.); eroded Culmacanthus scales show superposed growth zones (Long, 1983); Obtusacanthus is monodontode, so is coded (-) for this character; Ptomacanthus is coded (1) based on Brazeau (2012, fig. 7A, D). Cladoselache and Coccosteus are also coded (0). However, some taxa (Ptomacanthus and Nerepisacanthus) have body scales showing concentric growth, as well as other post-tectal scales showing areal growth crowns. For this reason, we have added a new character 260 to code for the latter type.

10. Body scales with peg-and-socket articulation: absent (0); present (1).

Brachyacanthus and Rhadinacanthus are coded (0) based on CJB (pers. obs.) and Gross (1947); Vernicomacanthus is coded (0) based on the description by Miles (1966).

11. Body scale profile: distinct crown and base demarcated by a constriction (neck) (0); flattened (1).
Brachyacanthus, Climatius, and Doliodus are coded (1), Diplacanthus and Rhadinacanthus are coded (0) based on Gross (1947); Parexus is coded (1) based on Burrow et al. (2013).

12. Body scales with bulging base: absent (0); present (1).

Doliodus and Diplacanthus are coded (0), Mesacanthus and Rhadinacanthus are coded (1), based on Gross (1947) and this paper; Lupopsyrus is coded ( 0 ) based on Hanke and Davis (2012); Parexus is coded (0) based on Burrow et al. (2013).

13. Body scales with flattened base: absent (0); present (1).

Lupopsyrus and Parexus are coded (1); Rhadinacanthus is coded ( 0$)$ based on this paper.

14. Flank scale alignment: vertical rows (0); oblique rows or hexagonal/rhombic packing (1); disorganised (2).

Rhadinacanthus is coded (1) based on this paper.

15. Sensory line canal: passes between or beneath scales (0); passes over scales and/or is partially enclosed or surrounded by scales (1); perforates and passes through scales (2).

Sensory lines pass between the specialised 'umbellate' scales on the head of Brochoadmones (Hanke and Wilson, 2006); there is no sign of sensory lines on the head tesserae of Cassidiceps (Gagnier and Wilson, 1996), and the lateral lines run between scales. Uraniacanthus is recoded (0) as lateral lines run between scales, and the infraorbital sensory line appears to run between scales and a circumorbital plate (Hanke and Davis, 2008, fig. 7C), not over scales.

16. Sensory line network: preserved as open grooves (sulci) in dermal bones (0); sensory lines pass through canals enclosed within dermal bones (1).

For all acanthodians which lack dermal bones, this character is coded (-), inapplicable.

17. Jugal portion of infraorbital canal joins supramaxillary canal: present (0); absent (1).

18. Dermal skull roof: includes large dermal plates (0); consists of undifferentiated plates or tesserae (1).

Rhadinacanthus is coded (1) based on NMS specimens (this paper).

19. Tessera morphology: large interlocking polygonal plates (0); microsquamose, not larger than body squamation (1).

Rhadinacanthus and Vernicomacanthus are coded (1) based on NMS specimens (this paper; CJB pers. obs.).

20. Extent of dermatocranial cover: complete (0); incomplete (scale-free cheek and elsewhere) (1). 
Mesacanthus and Rhadinacanthus are coded (0) based on NMS specimens (this paper; CJB pers. obs.).

21. Endolymphatic ducts open in dermal skull roof: present (0); absent (1).

For consistency, this character is coded as (?) in all acanthodians with plates larger than scales and tesserae on the skull roof, and (-) for those with scales or tesserae, as none of these taxa have plates on the skull roof so the character is inapplicable. Doliodus should be coded (?), as its head cover is not known.

22. Endolymphatic ducts with oblique course through dermal skull bones: absent (0); present (1).

23. Series of paired median skull roofing bones that meet at the dorsal midline of the skull (rectilinear skull roof pattern): absent (0); present (1).

All acanthodians which lack dermal skull roof plates should be coded (-), inapplicable.

24. Consolidated cheek plates: absent (0); present (1).

Diplacanthus, Rhadinacanthus and Culmacanthus have cheek plates, Cheiracanthus, Climatius, Lupopsyrus and Mesacanthus do not (Watson, 1937; Hanke and Davis, 2012; Burrow et al., 2015; CJB pers. obs.). This character is coded (1) for Uraniacanthus and Culmacanthus (Long 1983, fig. 3A) which have plates posterior to the circumorbital series in a comparable position to the cheek plate of (other) diplacanthiforms. This element differs from character 26, which refers to an element posterodorsal to the orbit (present in Climatius and Parexus).

25. Pineal opening perforation in dermal skull roof: present (0); absent (1).

Once again, for consistency, this character should be coded as (?) in all acanthodians which have a dermal skeleton (whether scales or tesserae or plates) over the skull roof, rather than (-) in some and (?) in others, and also for Doliodus, where presence/absence of a dermal cover is unknown.

26. Enlarged postorbital tessera separate from orbital series, over the otic region: absent (0); present (1).

The structure in Uraniacanthus appears to be posterior to the circumorbital bones (Hanke and Davis, 2008, fig. 5), and is in the same position as the cheek plates of (other) diplacanthiforms; Lupopsyrus lacks any large tesserae in the cheek/ postorbital region (Hanke and Davis, 2012, figs. 1, 2 ) and is coded (0).

27. Bony hyoidean gill-cover series (branchiostegals): absent (0); present (1).

Davis et al. (2012) coded Acanthodes as state (0), although they admitted that the objectivity of their recoding of this character from previous analyses was questionable; nor did they give any evidence to support their reinterpretation of the structures as endoskeletal rather than dermal elements. The only character by which these structures in Acanthodes and Homalacanthus differ from those in other acanthodiforms appears to be their lack of ornament. We maintain the traditional view that the thin rays/plates in Acanthodes and Homalacanthus are dermal structures homologous with those in other acanthodiforms, and code them as (1). The following characters 28-31 are also recoded for these two taxa, in line with our interpretation of these structures. Obtusacanthus lacks branchiostegals (Hanke and Wilson, 2004) and is coded $(0)$, with the following characters 2831 coded (-) inapplicable.

28. Branchiostegal plate series along ventral margin of lower jaw: absent (0); present (1).

Parexus has elongated diamond-shaped plates below the angle of the jaw, but they are possibly not homologous with the branchiostegal plates above the jaw angle and so are coded (?); Climatius is coded (1) and Rhadinacanthus coded (0), based on CJB (pers. obs.).

29. Branchiostegal ossifications plate-like (0); narrow and ribbon-like (1).

These structures are plate-like in Euthacanthus (Watson, 1937).

30. Branchiostegal ossifications ornamented (0); unornamented (1).

These structures are ornamented in Euthacanthus and Cheiracanthus (Watson, 1937; Miles, 1966).

31. Imbricated branchiostegal ossifications: absent (0); present (1).

The ossifications are separated in Acanthodes, Cheiracanthus and Homalacanthus, so are coded (0); they are contiguous in Brachyacanthus and Climatius, but it is unclear if they overlap and so these taxa are coded (?); in Ischnacanthus the ossifications are irregularly shaped, but appear to be separate, so it is coded (0).

32. Opercular cover of branchial chamber complete or partial (0); separate gill covers and gill slits (1).

Vernicomacanthus has branchiostegal plates (Miles, 1973a), so is coded (0).

33. Opercular (submarginal) ossification: absent (0); present (1).

Acanthodians with micromeric dermal covering on the head are coded (0); those with plates between the orbits and branchial plates which are larger than tesserae and scales, including diplacanthiforms, are coded (?), as it is unclear if any of these plates are homologous with submarginal plates.

34. Shape of opercular (submarginal) ossification: broad plate that tapers towards its proximal end (0); narrow, rod-shaped (1). 
35. Gular plates: absent (0); present (1).

Acanthodians Climatius and Parexus have fine short gular 'rays' anteroventral to the branchiostegals, but these structures are not morphologically comparable with the gular plates of osteichthyans and Entelognathus and so coding as $(0)$ is retained. Poracanthodes and Rhadinacanthus are coded (0) rather than (?), as they (like other acanthodians with this region preserved) show no evidence for such plates; these taxa are thus coded (-) for character

36. Size of lateral gular plates: extending most of length of the lower jaw (0); restricted to the anterior third of the jaw (no longer than the width of three or four branchiostegals) (1).

37. Basihyal: present (0); absent, hyoid arch articulates directly with basibranchial (1).

38. Interhyal: absent (0); present (1).

39. Oral dermal tubercles borne on jaw cartilages: absent (0); present (1).

Brachyacanthus, Culmacanthus, Euthacanthus and Rhadinacanthus all lack teeth or tooth-like structures on the jaws (Watson 1937, Burrow and Young, 2012; CJB pers. obs.). Taxa coded (0) for this character are coded (-) for characters 40-43. Achoania is coded (1) (Zhu et al., 2001).

40. Tooth whorls: absent (0); present (1).

This character could possibly be considered independent of character 39 , as symphysial tooth whorls appear to have developed between and not on the jaw cartilages, and extraoral elements indistinguishable from tooth whorls occur in some ischnacanthids (Blais et al., 2011). Tetanopsyrus lacks tooth whorls (Hanke et al., 2001) and is coded (0).

41. Bases of tooth whorls: single, continuous plate (0); some or all whorls consist of separate tooth units (1).

42. Enlarged adsymphysial tooth whorl: absent (0); present (1).

43. Teeth ankylosed to dermal bones: absent (0); present (1).

Brochoadmones, Climatius, Parexus and Vernicomacanthus have only separate tooth whorls borne on jaw cartilages and are coded (0). Tetanopsyrus lindoei (Hanke et al., 2001, fig. 3B) has rounded 'denticles' on the lingual surface of otherwise smooth occlusal surfaces on the jaw cartilages, but these appear to be ossified bumps rather than teeth, so Tetanopsyrus is coded as (0).

44. Dermal jaw plates on biting surface of jaw cartilages: absent (0); present (1).

It is uncertain if the occlusal jaw plates in diplacanthiforms and Tetanopsyrus are dermal or endoskeletal developments. Like Diplacanthus, other diplacanthiforms Culmacanthus, Uraniacanthus and Rhadinacanthus have smooth plates on the Meckel's cartilages (Burrow and Young, 2012; Newman et al., 2012; CJB pers. obs.), whereas Tetanopsyrus has mineralized upper and lower jaws, with no distinct separation between the biting surface and the rest of the jaw (Hanke et al., 2001, fig. 3A, B). We have added a new character 259 for smooth surfaced occlusal dental plates.

45. Maxillary and dentary tooth-bearing bones: absent (0); present (1).

Cassidiceps and Kathemacanthus are coded (0), as there is no evidence of these bones in the mouth region of either species.

46. Large otic process of the palatoquadrate: absent (0); present (1).

Euthacanthus has a palatoquadrate of typical acanthodian shape, and is coded (1) for this and character 47.

47. Insertion area for jaw adductor muscles on palatoquadrate: ventral or medial (0); lateral (1).

This character is uncertain for Kathemacanthus (Hanke and Wilson, 2010, fig. 6A), and coded (?).

48. Oblique ridge or groove along medial face of palatoquadrate: absent (0); present (1).

Climatius has this feature, and is coded (1).

49. Fenestration of palatoquadrate at basipterygoid articulation: absent (0); present (1).

Mesacanthus and Poracanthodes both lack a fenestration, and are coded (0), based on CJB (pers. obs.) and Valiukevičius (1992).

50. Perforate or fenestrate anterodorsal (metapterygoid) portion of palatoquadrate: absent (0); present (1).

51. Pronounced dorsal process on Meckelian bone or cartilage: absent (0); present (1).

Culmacanthus dental plates have this process (Burrow and Young, 2012, fig. 4a, b), and it is coded (1); Diplacanthus plates lack the process and it is coded (0); Euthacanthus cartilages lack a process and it is also coded (0).

52. Preglenoid process: absent (0); present (1).

The jaw articulation area is poorly preserved in all Climatius reticulatus institutional specimens, and presence or absence of this process is uncertain; Climatius is coded (?).

53. Jaw articulation located on rearmost extremity of mandible: absent (0); present (1).

54. Precerebral fontanelle: absent (0); present (1).

55. Median dermal bone of palate (parasphenoid): absent (0); present (1).

Despite examples with the inferred palatal region being preserved in all acanthodians in this analysis, none show evidence for a palatal bone, so they are all coded as (0). Several previous analyses (Brazeau, 2009; Davis et al., 2012; Zhu et al., 2013) coded most acanthodians as (?), unknown, but if there was a bone, whether denticulated or 
not, then it would be visible in acanthodians which have the head region preserved, even if none of the cartilaginous endoskeleton is preserved. We can often see both the external surface features of the exposed side, as well as the internal surfaces of the other side of the fish, particularly in the MOTH fishes but also in many LORS acanthodian species - if there was a bone between the two sides of the head, then it should be visible, at least as a lump in the scale/tessera cover or exposed when the upper dermal cover is incomplete. Given the excellent preservation of MOTH fish, where even statoconia are easily seen, an actual bone would be visible when the head region is preserved.

56. Nasal opening(s): dorsal, placed between orbits (0); ventral and anterior to orbit (1).

Nares have been identified anterior to the orbits in Culmacanthus (Long, 1983), Diplacanthus (Watson, 1937), Euthacanthus (Newman et al., 2014), Parexus (Burrow et al., 2013), and Nerepisacanthus (Burrow and Rudkin, 2014), and these are coded as (1).

57. Olfactory tracts: short, with olfactory capsules situated close to telencephalon cavity (0); elongate and tubular (much longer than wide) (1).

58. Prominent pre-orbital rostral expansion of the neurocranium: present (0); absent (1).

Recently described specimens of Lupopsyrus (Hanke and Davis, 2012), and NMS specimens of Rhadinacanthus (CJB pers. obs.) indicate coding (1) for these taxa.

59. Pronounced sub-ethmoidal keel: absent (0); present (1).

60. Position of myodome for superior oblique eye muscles: posterior and dorsal to foramen for nerve II (0); anterior and dorsal to foramen (1).

61. Endoskeletal intracranial joint: absent (0); present (1).

62. Spiracular groove on basicranial surface: absent (0); present (1).

63. Spiracular groove on lateral commissure: absent (0); present (1).

64. Subpituitary fenestra: absent (0); present (1).

65. Supraorbital shelf broad with convex lateral margin: absent (0); present (1).

Kathemacanthus is coded (?) as this region is not preserved in any specimens reliably assignable to the genus (Hanke and Wilson, 2010).

66. Orbit dorsal or facing dorsolaterally, surrounded laterally by endocranium: present (0); absent (1).

In Cheiracanthus, Climatius, Euthacanthus, Ischnacanthus, Mesacanthus and Promesacanthus the orbits are positioned laterally, and edged posteriorly and posteroventrally by the palatoquadrate, precluding the endocranium surrounding the orbit laterally.
67. Extended prehypophysial portion of sphenoid: absent (0); present (1).

68. Narrow interorbital septum: absent (0); present (1).

69. The main trunk of facial nerve (N. VII): elongate and passes anterolaterally through orbital floor (0); stout, divides within otic capsule at the level of the postorbital process (1).

70. Hyoid ramus of facial nerve (N. VII) exits through posterior jugular opening: absent (0); present (1).

71. Glossopharyngeal nerve (N. IX) exit: foramen situated posteroventral to otic capsule and anterior to metotic fissure (0); through metotic fissure (1).

72. Short otico-occipital region of braincase: absent (0); present (1).

73. Ethmoid region elongate with dorsoventrally deep lateral walls: absent (0); present (1).

74. Basicranial morphology: platybasic (0); tropibasic (1).

75. Ascending basisphenoid pillar pierced by common internal carotid: absent (0); present (1).

76. Jugular vein: invested in otic capsule wall posterior to the postorbital process (0); lateral wall of jugular canal incomplete or absent (1).

77. Canal for lateral dorsal aorta within basicranial cartilage: absent (0); present (1).

78. Entrance of internal carotids: through separate openings flanking the hypophyseal opening or recess $(0)$; through a common opening at the midline of the basicranium (1).

79. Canal for efferent pseudobranchial artery within basicranial cartilage: absent (0); present (1).

80. Position of basal/basipterygoid articulation: same anteroposterior level as hypophysial opening (0); anterior to hypophysial opening (1).

81. Postorbital process articulates with palatoquadrate: absent (0); present (1).

82. Labyrinth cavity separated from the main neurocranial cavity by a cartilaginous or ossified capsular wall (0); skeletal capsular wall absent (1).

83. Basipterygoid process (basal articulation) with vertically oriented component: absent (0); present (1).

84. Pituitary vein canal dorsal to level of basipterygoid process (0); flanked posteriorly by basipterygoid process (1).

85. External (horizontal) semicircular canal: absent (0); present (1).

86. Sinus superior: absent or indistinguishable from union of anterior and posterior canals with saccular chamber (0); present (1).

Following Dupret et al. (2014), this character has been recoded (1) for Galeaspida.

87. External (horizontal) semicircular canal: joins the vestibular region dorsal to posterior ampulla (0); 
joins the vestibular region levelling with posterior ampulla (1).

88. Trigemino-facial recess: absent (0); present (1).

89. Posterior dorsal fontanelle: absent (0); present (1).

90. Shape of posterior dorsal fontanelle: approximately as long as broad (0); much longer than wide, slot-shaped (1).

91. Dorsal ridge: absent (0); present (1).

92. Endolymphatic ducts: posteriodorsally angled tubes (0); tubes oriented vertically through median endolymphatic fossa (1).

93. Lateral otic process: absent (0); present (1).

94. Process forming part or complete wall of jugular groove or canal projecting from otic capsule wall: absent (0); present (1).

95. Position of hyomandibula articulation on neurocranium: below or anterior to orbit, on ventrolateral angle of braincase (0); posterior to orbit (1).

96. Ventral cranial fissure: absent (0); present (1).

97. Metotic (otic-occipital) fissure: absent (0); present (1).

98. Vestibular fontanelle: absent (0); present (1).

99. Occipital arch wedged in between otic capsules: absent (0); present (1).

100. Spino-occipital nerve foramina: two or more, aligned horizontally (0); one or two, aligned dorsoventrally (1).

101. Ventral notch between parachordals: absent (0); present or entirely unfused (1).

102. Parachordal shape: broad, flat (0); keeled with sloping lateral margins (1).

103. Hypotic lamina (and dorsally directed glossopharyngeal canal): absent (0); present (1).

104. Macromeric dermal shoulder girdle: present (0); absent (1).

105. Dermal shoulder girdle composition: ventral and dorsal (scapular) components (0); ventral components only (1).

Diplacanthus was previously coded (0), but the dermal ornament on the scapula comprises scales and tesserae attached to the endoskeletal scapula; Rhadinacanthus and Vernicomacanthus also lack dorsal components (NMS collection, CJB pers. obs.).

106. Dermal shoulder girdle forming a complete ring around the trunk: present (0); absent (1).

All acanthodians with a dermal shoulder girdle component are coded (1), as all acanthodian taxa in the analysis lack a dermal bone component to the dermal shoulder girdle so cannot have a complete ring; other acanthodians are coded (-).

107. Pectoral fenestra completely encircled by dermal shoulder armour: present (0); absent (1).
All acanthodians with a dermal shoulder girdle component are coded (1), as they lack a dermal component to the dermal shoulder girdle so the pectoral fenestra cannot be completely encircled; other acanthodians are coded (-).

108. Median dorsal plate: absent (0); present (1).

109. Pronounced internal crista ('keel') on median dorsal surface of shoulder girdle: absent (0); present (1).

110. Scapular process of endoskeletal shoulder girdle: absent (0); present (1).

111. Ventral margin of separate scapular ossification: horizontal (0); deeply angled (1).

Euthacanthus is coded (0); Rhadinacanthus is coded (1), based on CJB pers. obs.

112. Cross-sectional shape of scapular shaft: flattened or strongly ovate (0); subcircular (1).

Cassidiceps is coded (0), based on Gagnier and Wilson (1996, p. 253: scapular blade is short and has a flat internal face"); Culmacanthus (Long, 1983, fig. 6) and Diplacanthus are coded (1), based on NMS specimens (CJB pers. obs.); Lupopsyrus is coded (0); Uraniacanthus is coded (1), as the central shaft is subcircular in crosssection, even though the anterior and posterior flanges give the scapula a flattened appearance.

113. Flange on trailing edge of scapulocoracoid: absent (0); present (1).

Although the flange is not as large as on Diplacanthus, Culmacanthus has a short flange so is coded (1).

114. Scapular process with posterodorsal angle: absent (0); present (1).

Rhadinacanthus and Vernicomacanthus lack this feature and are coded (0), based on NMS specimens (CJB pers. obs.).

115. Endoskeletal postbranchial lamina on scapular process: present (0); absent (1).

Lupopsyrus lacks this structure (Hanke and Davis, 2012, fig. 5) and is coded (1); Promesacanthus appears to have a triangular region anteriorly on the scapula (Hanke, 2008, fig. 4) which could possibly be interpreted as a postbranchial lamina, so it is coded (?); Rhadinacanthus is coded (0), based on NMS specimens (CJB pers. obs.). Following Dupret et al. (2014), Galeaspida has been recoded from (0) to (-).

116. Mineralisation of internal surface of scapular shaft: mineralised all around (0); unmineralised on internal face forming a hemicylindrical crosssection (1).

Davis et al. (2012) referred to a scapular blade, which is the notation used for the ventral expansion of the scapula; the dorsal portion is usually termed the scapular shaft. In Lupopsyrus, the shaft is mineralised all around so it is coded (0); in Mesacanthus, only the internal face is ossified 
(CJB pers. obs.), so it is coded (1); Rhadinacanthus scapulocoracoid resembles that of Diplacanthus, and is coded (0), based on CJB (pers. obs.); in Tetanopsyrus the flattened preservation of the structure (Hanke et al., 2001, figs. 2A, 3E, 6A) precludes an assessment of the extent of mineralisation, so it is coded (?).

117. Coracoid process: absent (0); present (1).

As listed by Brazeau (2009), this character appears to necessarily refer to a mineralised process. If so, then Climatius, Euthacanthus, Ischnacanthus, Lupopsyrus, Parexus, Poracanthodes and Rhadinacanthus should be coded (0), as they have perichondrally ossified scapulas with a straight ventral margin, lacking any processes. Brochoadmones coding is changed to (-) as the pectoral girdle is not mineralised; Uraniacanthus is coded (?), as this region is not well preserved in any figured specimens, a coracoid process is not mentioned in the description by Hanke and Davis (2008) and their figure 8B is apparently based on a distorted specimen (Hanke and Davis, 2008, p. 314).

118. Procoracoid mineralisation: absent (0); present (1).

Diplacanthus, Rhadinacanthus have a mineralised procoracoid (CJB pers. obs. of NMS specimens), so are coded (1).

119. Fin base articulation on scapulocoracoid: stenobasal (0); eurybasal (1).

All acanthodians probably have a stenobasal articulation, but only those in which the fin is preserved have been coded (0); other taxa have been left as (?).

120. Perforate propterygium: absent (0); present (1).

121. Pelvic fins: absent (0); present (1).

122. Pelvic claspers: absent (0); present (1).

All acanthodian taxa in which the pelvic region is preserved, with pelvic fin spines and often pelvic fins, lack any mineralised structures which could be interpreted as pelvic claspers, and are thus coded (0). Cladoselache has been coded (?), after Long et al. (2015). The extra and revised codings added by the latter have not been included.

123. Dermal pelvic clasper ossifications: absent (0); present (1).

If taxa are coded $(0)$ for character 122 , then they are now coded (-) for this character.

124. Pectoral fins covered in macromeric dermal armour: absent (0); present (1).

125. Pectoral fin base has large, hemispherical dermal component: absent (0); present (1).

126. Dorsal fin spines: absent (0); present (1).

127. Anal fin spine: absent (0); present (1).
128. Paired pectoral fin spines: absent (0); present (1).

129. Median fin spine insertion: shallow, not greatly deeper than dermal bones/ scales (0); deep (1).

Kathemacanthus, Lupopsyrus, Obtusacanthus, Parexus, Poracanthodes and Vernicomacanthus all have shallowly inserted median spines, so are coded (0).

130. Prepelvic fin spines: absent (0); present (1).

This character was previously "intermediate fin spines", and included admedian spines medial to the pectoral fin spines. Admedian spines are here considered different structures, and coded as a separate character (256).

131. Prepectoral fin spines: absent (0); present (1).

The spine series between the pectoral spines in Kathemacanthus are regarded here as admedian (new character 256) not prepectoral spines, so coding is changed to (0).

132. Fin spines with ridges: absent (0); present (1).

133. Median and paired fin spines with nodes: absent (0); present (1).

Prepectoral, admedian and prepelvic spines often have a different ornament to the median, pectoral and pelvic spines, so only the latter are coded here.

134. Dorsal fin spines with rows of large retrorse denticles: absent (0); present (1).

Both pectoral and dorsal fin spines with such denticles are known, but occur in different taxa. Orthacanthus and Parexus are coded (1). Pectoral fin spines with these denticles are here considered as separate character (258).

135. Synarcual: absent (0); present (1).

136. Number of dorsal fins, if present: one (0); two (1).

137. Anal fin: absent (0); present (1).

138. Caudal radials: extend beyond level of body wall and deep into hypochordal lobe (0); radials restricted to axial lobe (1).

Characters added by Zhu et al. (2013)

\section{Skeletal Tissues}

139. Resorption and redeposition of odontodes: lacking or partially developed (0); developed (1).

No acanthodian taxa in which histological structure of scales and spines have been investigated, show evidence for resorption, so such taxa have been recoded (0).

140. Acrodin: absent (0); present (1).

Taxa lacking teeth are coded (-); Climatius, Doliodus, Ischnacanthus, Parexus, Poracanthodes and Ptomacanthus are coded (0), as the histological structure of their teeth has been studied and acrodin is lacking.

141. Plicidentine: absent (0); simple or generalized polyplacodont (1). 
Taxa lacking teeth are coded (-); the same acanthodians listed in 140 are also coded (0) for this character.

142. Rostral tubuli: absent (0); present (1).

\section{Dermal Skeleton: scales and fins}

143. Peg on rhomboid scale: narrow (0); broad (1).

144. Anterodorsal process on scale: absent (0); present (1).

145. Fringing fulcra: absent (0); present (1). No acanthodians (or chondrichthyans) known from specimens with fins preserved have lepidotrichia (although most have rows of scales on the fins, they are not regarded as being homologous with lepidotrichia); none can then have fringing fulcra (specialised lepidotrichia), and should be coded (-), inapplicable for this and character 146.

146. Epichordal lepidotrichia in caudal fin: absent (0); present (1).

\section{Dermal Skeleton: skull}

147. Dermal intracranial joint: absent (0); present (1).

148. Large unpaired median skull roofing bone anterior to the level of nasal capsules: absent (0); present (1).

149. Number of nasals: many (0); one or two (1).

Clearly defined specialized bones surrounding the nares are known in a number of acanthodians, including Brochoadmones, Cassidiceps, Climatius, Culmacanthus, Euthacanthus, Ischnacanthus, Homalacanthus, Mesacanthus, Nerepisacanthus, Ptomacanthus, so these taxa are coded (0). Other acanthodians with plates larger than scales and tesserae in the head region could possibly have nasals as well, and so are coded (?).

150. Mesial margin of nasal: not notched (0); notched (1).

Acanthodians with nasals have a ring of bones rather than a single nasal bone, and so their coding as (-), inapplicable, is retained.

151. Dermintermedial process: absent (0); present (1).

152. Posterior nostril: associated with orbit (0); not associated with orbit (1).

Culmacanthus has two pairs of nares (Long, 1983, fig. 5), and is coded (1); although their presence or absence is uncertain in other acanthodians, they should all be coded (?), rather than some as (-) and others as (?).

153. Position of posterior nostril: external, far from jaw margin (0); external, close to jaw margin (1).

The position of the posterior nostril is between the orbits and far from the jaw margin in Culmacanthus, so it is coded (0); all other acanthodians are coded (?).
154. Supraorbital (sensu Cloutier and Ahlberg, 1996, including posterior tectal of Jarvik): absent (0); present (1).

155. Supraorbital, preorbital and nasal: unfused (0); fused (1).

156. Tectal (sensu Cloutier and Ahlberg, 1996, not counting the 'posterior tectal' of Jarvik): absent (0); present (1).

157. Lateral plates: absent (0); present (1).

158. Location of pineal foramen/eminence: level with posterior margin of orbits (0); well posterior of orbits (1).

159. Parietals (preorbitals of placoderms) surround pineal foramen/eminence: yes (0); no (1).

160. Complete enclosure of spiracle by skull-roof bones: absent (0); present (1).

161. Number of marginal bones alongside paired median skull roofing bones over the otico-occipital division of braincase: single (0); two or more (1).

162. Number of paranuchals: one pair (0), two pairs (1).

163. Large unpaired median bone contributing to posterior margin of skull roof: absent (0); present (1).

164. Contact of nuchal or centronuchal plate with paired preorbital plates: absent (0), present (1).

165. Posterior process of the paranuchal plate behind the nuchal plate (dorsal face): absent (0), present (1).

166. Junction of posterior pitline and main lateral line: far in front of posterior margin of skull roof $(0)$, close to posterior margin of skull roof (1).

167. Number of extrascapulars: uneven (0); paired (1).

168. Dermal neck-joint between paired main-lateralline-bearing bones of skull and shoulder girdle: absent (0); present (1).

169. Type of dermal neck-joint: sliding, dermal shoulder girdle plate with flat articluar flange (0); ginglymoid, dermal shoulder girdle plate with articular condyle or fossa (1)

170. Number of sclerotic plates: four or less (0); more than four (1).

As noted by Burrow et al. (2011), most acanthodians have a sclerotic ring comprising five or six plates: codings for Brachyacanthus, Climatius, Euthacanthus, Parexus and Ptomacanthus are accordingly changed to (1); codings for acanthodians Brochoadmones, Diplacanthus, Uraniacanthus, Ischnacanthus, Kathemacanthus, Lupopsyrus, Obtusacanthus, Rhadinacanthus and Tetanopsyrus are changed to $(-)$ as these taxa lack a sclerotic ring (see new character 258).

171. Foramina (similar to infradentary foramina) on cheek bones: absent (0); present (1).

172. Lacrimal posteriorly enclosing posterior nostril: absent (0); present (1). 
173. Most posterior major bone of cheek bearing preopercular canal ("preopercular") extending forward, close to orbit: absent (0); present (1).

Acanthodes, Brochoadmones, Cheiracanthus, Euthacanthus, Uraniacanthus, Ischnacanthus, Kathemacanthus, Lupopsyrus, Mesacanthus, Obtusacanthus, Poracanthodes, Promesacanthus and Tetanopsyrus have only scales or tesserae in the cheek region, so are coded (-).

174. Number of cheek bones bearing preopercular canal posterior to jugal: one (0); two (1).

175. Bone bearing both quadratojugal pit-line and preopercular canal: absent (0); present (1).

176. Dermohyal: absent (0); present (1).

Acanthodians with micromeric head covering must lack a dermohyal, so are coded $(0)$.

177. Premaxillae with inturned symphysial processes: absent (0); present (1).

Acanthodians lack premaxillae and maxillae, and so are coded (-) for characters 177-182.

178. Premaxilla forming part of orbit: absent $(0)$; present (1).

179. Preorbital process of premaxilla: absent (0); present (1).

180. Posterior expansion of maxilla (maxilla cleavershaped): present (0); absent (1).

181. Ventral margin of maxilla: straight (0), curved (1).

182. Contribution by maxilla to posterior margin of cheek: present (0); absent (1).

183. Course of ethmoid commissure: middle portion through median rostral (0); sutural course (1); through bone center of premaxillary (2).

184. Position of anterior pit-line: on paired median skull roofing bones over the otico-occipital division of braincase (0); on paired median skull roofing bones over the sphenoid division of braincase (1). Acanthodians with only scales or tesserae as dorsal head cover are coded (-), inapplicable.

185. Middle and posterior pit-lines on postparietal: posteriorly situated (0), mesially situated (1).

186. Position of middle and posterior pit-lines: close to midline (0); near the central portion of each postparietal (1).

187. Course of supraorbital canal: between anterior and posterior nostrils (0); anterior to both nostrils (1).

188. Course of supraorbital canal: straight (0); lyreshaped (1).

189. Posterior end of supraorbital canal: in postparietal (0); in parietal (1); in intertemporal (2).

Acanthodians with only scales or tesserae as dorsal head cover are coded (-), inapplicable.

190. Contact between otic and supraorbital canals: not in contact (0); in contact (1).
In Acanthodes, Diplacanthus, Euthacanthus, Homalacanthus and Ischnacanthus, these two canals are separate and so coded (0), based on Watson (1937) and Miles (1966).

191. Contact of supraorbital and infraorbital canals: in contact rostrally (0); not in contact rostrally (1).

192. Otic canal: runs through skull roof (0); follows edge of skull roof (1).

193. Infraorbital canal follows premaxillary suture: no (0); yes (1).

194. Sensory canal or pit-line associated with maxilla: absent (0); present (1).

195. Anterior portion of preopercular canal: present (0); absent (1).

\section{Dermal Skeleton: operculogular series}

196. Median gular: present (0); absent (1).

Rhadinacanthus and Obtusacanthus lack dermal bones in the gular region, and so are coded (-).

\section{Branchial skeleton}

197. Foramen in hyomandibular: absent (0); present (1).

\section{Dentition and mandibular arch}

198. Large dermal plates forming outer dental arcade: only with denticles $(0)$, with a monolinear series of large, shedding teeth (1).

Toothed acanthodians are considered to lack an outer dental arcade, with dermal jaw bones of ischnacanthiforms and diplacanthiforms homologous with the coronoid series of osteichthyans (both being on the upper side of the Meckel's cartilage/bone). No other acanthodians in which this region is preserved have large dermal plates forming an outer dental arcade, and so are coded $(-)$.

199. Tooth-bearing median rostral: absent (0); present (1).

Culmacanthus has a median rostral bone, but it is not at the jaw margin, and is coded (-) as we cannot be certain it is homologous with the median rostral in osteichthyans. Other acanthodians that lack teeth are also coded (-), inapplicable.

200. Teeth of dentary: reaching anterior end of dentary (0); not reaching anterior end (1).

All acanthodians are coded (-), as they lack an outer dental arcade.

201. Number of coronoids (sensu lato, including parasymphysial dental plate but excluding parasymphysial tooth whorl): more than three (0); three (1).

202. Fangs of coronoids (sensu stricto): absent (0); present (1). 
203. Marginal denticle band on coronoids: broad band, at least posteriorly (0); narrow band with 2-4 denticle rows (1).

204. Infradentary bones: absent (0), present (1).

205. Infradentary foramina: always present $(0)$; variable (1); always absent (2).

206. Large ventromesially directed flange of symphysial region of mandible: absent (0); present (1).

No acanthodians have an ossified mandible sensu stricto, and so are coded (-) for this and character 208.

207. Flange-like extension composed of Meckelian ossification and prearticular that extends below ventral margin of infradentaries: absent $(0)$, present (1).

208. Strong ascending flexion of symphysial region of mandible: absent (0); present (1).

209. Parasymphysial plate: detachable tooth whorl (0); long with posterior corner, sutured to coronoid, denticulated or with tooth row (1); absent (2).

No acanthodians have a parasymphysial plate, so are all coded (-).

210. Anterior end of prearticular: far from jaw symphysis (0); near jaw symphysis (1).

No acanthodians have a prearticular, so are all coded (-).

211. Prearticular-dentary contact: present (0); absent (1).

212. Meckelian bone exposed immediately anterior to first coronoid: yes (0); no (1).

213. Dermal plates on mesial (lingual) surfaces of Meckel's cartilage and palatoquadrate: absent (0); present (1).

In all acanthodians with dental plates, these elements are on the dorsal surface of the Meckel's cartilage and ventral surface of the palatoquadrate, so all acanthodians are coded (0).

214. Biconcave glenoid on lower jaw: absent (0); present (1).

Ischnacanthus, Mesacanthus and Poracanthodes all have a simple jaw joint, so are coded (0).

215. Contact between palatoquadrate and dermal cheek bones: continuous contact of metapterygoid and autopalatine (0); metapterygoid and autopalatine contacts separated by gap between commissural lamina of palatoquadrate and cheek bones (1).

Acanthodians with only microsquamose cheek covering are coded (-), inapplicable.

216. Metapterygoid with developed mesial ventral protrusion (i.e. commissural lamina sensu stricto): absent (0); present (1).

217. Course of mandibular canal: not passing through most posterior infradentary (0); passing through most posterior infradentary (1).
Zhu et al. (2009, Character 119), and references therein.

218. Course of mandibular canal: passing through dentary (0); not passing through dentary (1).

\section{Neurocranium and palate}

219. Internasal pits: absent (0); undifferentiated or anterior palatal fossa (1); shallow, paired pits with strong midline ridge (2); deep, pear-shaped pits (3).

220. Fenestra ventrolateralis: absent (0); present (1); common ventral fenestra for anterior and posterior nostrils (2).

221. Ethmoid articulation for palatoquadrate: placed on postnasal wall (0); extends posteriorly to the level of N.II (1).

222. Eye stalk or unfinished area on neurocranial wall for eye stalk: absent (0); present (1).

223. Developed postorbital cavity: absent (0); present (1).

224. Postorbital pila ascending from basipterygoid process to postorbital process: absent (0); present (1).

225. Unconstricted cranial notochord: absent (0); present (1).

226. Descending process of sphenoid (with its posterior extremity lacking periostegeal lining): absent (0); present (1).

227. Articulation facet with hyomandibular: singleheaded (0), double-headed (1).

228. Hyoid arch articulation: on lateral commissure (0); on otic capsule wall (1).

229. Opercular suspension on braincase: absent (0); present (1).

230. Posterior postorbital process: absent (0); present (1).

231. Basicranial fenestra: absent (0); present (1).

232. Otical process (an outgrowth from the lateral wall of the braincase penetrated by the branches of the r. oticus lateralis): absent (0); present (1).

233. Lateral cranial canal: absent (0); present (1).

234. Midline canal in basicranium for dorsal aorta: absent (0); present (1).

235. Vomerine fangs: absent (0); present (1).

236. Vomeral area with grooves and raised areas: absent (0); present (1).

237. Parasphenoid: protruding forward into ethmoid region of endocranium (0); behind ethmoid region (1).

No acanthodians with this region preserved show evidence for a mineralised parasphenoid; Zhu et al. (2013) coded them all (-) for this character as well as 242 and 243, and they should also all be coded (-) for characters 238-241. 
238. Denticulated field of parasphenoid: without spiracular groove (0); with spiracular groove (1).

239. Ascending process of parasphenoid: absent $(0)$; present (1).

240. Shape of parasphenoid denticulated field: broad rhomboid or lozenge-shaped (0); broad, splintshaped (1); slender, splint-shaped (2).

241. Parasphenoid denticulated field with multifid anterior margin: absent (0); present (1).

242. Parasphenoid denticle field with anteriorly divergent lateral margins: absent (0); present (1).

243. Parasphenoid denticle field: terminates at or anterior to level of foramina for internal carotid arteries (0); extends posterior to foramina for internal carotid arteries (1).

\section{Paired fins and girdles}

244. Presupracleithrum: absent (0); present (1).

Climatius, Diplacanthus, Poracanthodes and Tetanopsyrus like all other acanthodians, have no dorsal dermal shoulder girdle plates, so are also coded (-).

245. Anocleithrum: element developed as postcleithrum (0); element developed as anocleithrum sensu stricto (1).

246. Dorsal cleithrum (AL of the Placodermi), ventral cleithrum (AVL of the Placodermi) and pectoral spine (SP of the Placodermi): not fused (0); fused (1).

247. Relationship of clavicle to cleithrum: ascending process of clavicle overlapping cleithrum laterally (0); ascending process of clavicle wrapping round anterior edge of cleithrum, overlapping it both laterally and mesially (1).

248. Triradiate scapulocoracoid: absent (0); present (1).

249. Subscapular foramen/fossa: absent (0); present (1).

Diplacanthus has subscapular foramen/foramina (Miles, 1973a, text-fig. 40) so is coded (1).

250. Endoskeletal supports in pectoral fin: multiple elements articulating with girdle (0); single element ("humerus") articulating with girdle (1).

251. Pectoral propterygium: absent (0); present (1). Zhu et al. (2009, Character 131), and references therein.

252. Pelvic girdle with substantial dermal component: yes (0); no (1).

No acanthodians where this region is well preserved show any evidence for a dermal compo- nent (other than the pelvic spines and enlarged scales), and so are coded (1).

\section{Fin spines}

253. Pelvic fin spine: absent (0); present (1).

Pelvic fin spines are known in all acanthodians in this analysis, so all taxa are coded (1). Characters added by Dupret et al. (2014)

254. Articulated jaws: absent (0); present (1).

255. Endocranial optic fissure: absent (0); present (1).

\section{New characters}

256. Admedian fin spines: absent (0); present (1).

The spines between the pectoral spines in Diplacanthus were named admedian pectoral spines by Watson (1937), but Miles (1973a) referred to them as "first intermediate spines". We consider that the admedian spines in diplacanthiforms and climatiids are not part of the "intermediate" (now usually called "prepelvic") paired spine series; the series of spines between the pectoral spines in Kathemacanthus (previously regarded as prepectoral spines) are also assessed as being an admedian series, separate to both the prepectoral and prepelvic spine series.

257. Fin spine insertion with fine parallel longitudinal ridges: absent (0); present (1).

258. Retrorse denticles on pectoral spine: absent (0); present (1).

Several diplacanthid and climatiid acanthodian taxa, as well as Doliodus, have rows of large denticles along the posterior edge(s) of the pectoral spines.

\section{Dermal structures}

259. Sclerotic plates: present (0); absent (1).

The wide distribution of dermal sclerotic plates amongst early gnathostomes, as well as in osteostracans, indicates sclerotic plates are a general condition for early gnathostomes (Burrow et al. 2011).

260. Postcranial scales with areal or appositional growth crowns: present (0); absent (1).

261. Dental plates with smooth occlusal surface: absent (0); present (1).

262. Scales with a canal system in the dentine of the crown, opening out through pores on the crown surface: absent (0); present (1).

This pore canal system differs to cosmine, as it only extends through the dentine and is not associated with bulbous pulp cavities extending into the underlying bone. 


\title{
APPENDIX 3.
}

Data matrix with 262 morphological characters for 77 taxa.

\section{MATRIX}

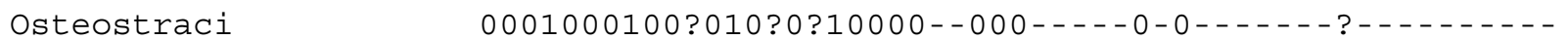
$00000000-? 0000000-000$ ? 0--- - ?0??00-00-?00??000-??000000-0??--?0-100-0-000?0?-

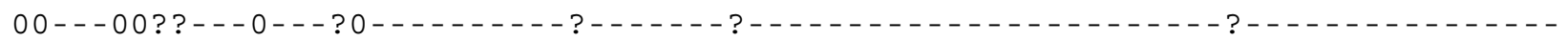
- - - - - ? 0? ? 0 ? ?-- - ? 0? ? - - - - - - - - ? ? 0-- 000--00?0

Galeaspida 0000-0-? ?00101?0?1000?--000------0------ ?-------000000 ? - ?0000000-000?0--- - ?0? ?01?00-?00? ?000-0000--- - - - ?-- ?-- - - - 0- ?-- ? ?-- ?-

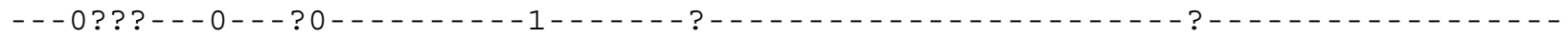
- - - - ? 0? ? - ? ? - - ? 0? ? - - - -
\end{abstract}

Acanthodes 000120011001011-0110-?-0?01110000-0-1?0--0011101010?01?1??010?0111?0110111010011001101101001111?001101---0-

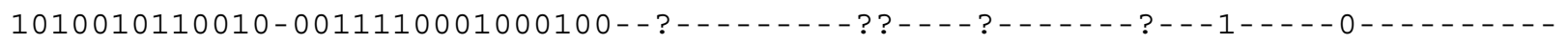

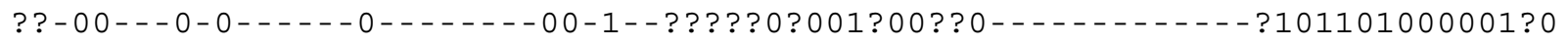

Achoania 001121 ????????1?0-

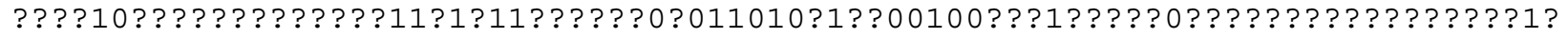

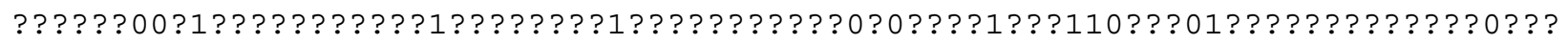
?100???????1010???1???1110??10101011011????30110111?????????010?0010??????01?0 100 ? - ???

Akmonistion 10012010?0-??21-?1?1----00----10-0-?011100011?000?0101010?01001110101100?111?11?001??110111010100?0011---0-1-

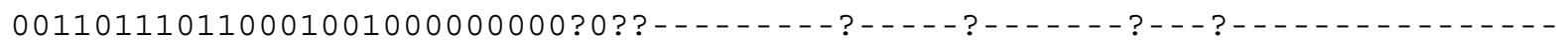

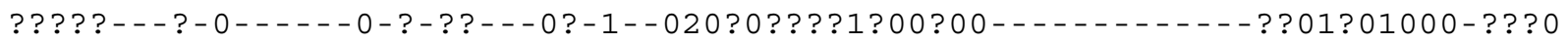

Austroptyctodus 0001?0?1?01010?1?0-?1-001-0----0110-0010-

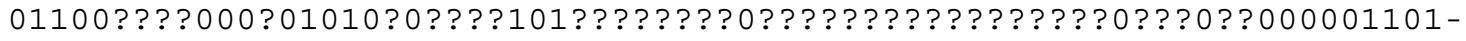

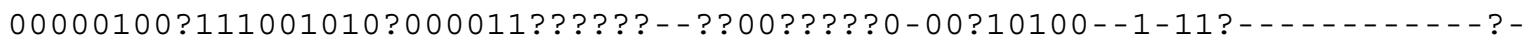

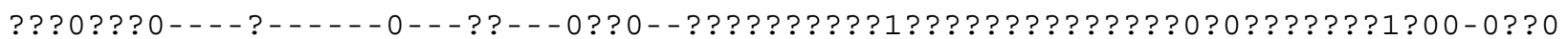

Bothriolepis 0000-0-?--?--?10?0-000010-0----0100-???---

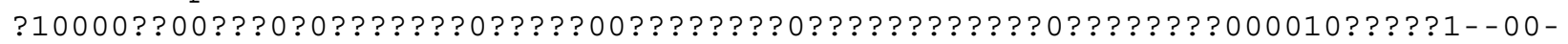

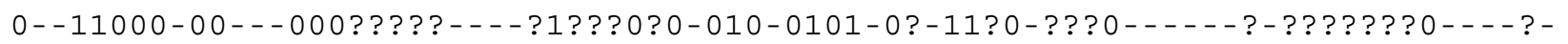
---- 0---02---0?00--?0??????????????????????0?0??? ?0--110--01?0

Brachyacanthus 00010001001?110??100??-0?11000?0??0-??0---00 ? ? ? ? ? ? 01 ? 1 ? ? ? ? ? ? ? ? ? ? ? ? ? ? ? ? ? ? ? ? ? ? ? ? ? ? ? ? ? ? ? $01110-$

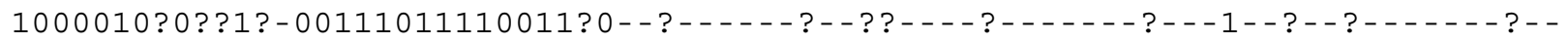


Brindabellaspis 000110?100010????0-?000?1-

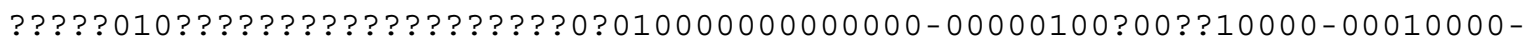

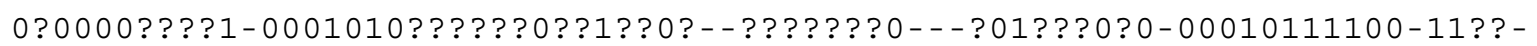

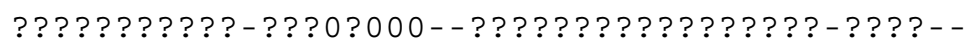

02 ? 100 ? ? ? 11 ? ?00? ? ? ? ? ? ? ? ? 0? ? ? ? 110 ? - ?0?0

Brochoadmones 0101000100?1110-0110??-0?00----10-0-

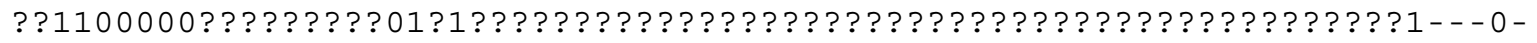

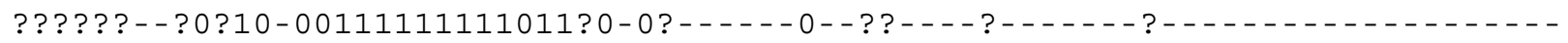

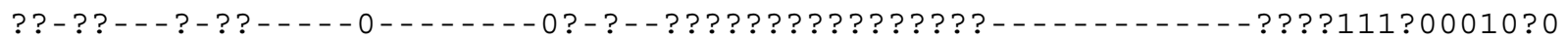

Buchanosteus 00?1?0?100010??0?0-001111-0----0110-??1-0?10010??0?001101000001010010-00000000?00??1000???0011000-0100000011?0?-1?1???????00?1??000-???????0---?00?????0-00010101011-11??-????--- - - ?-

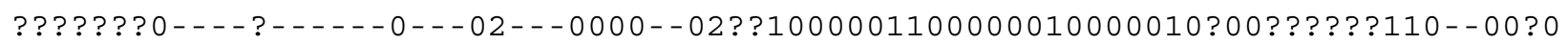

Campbellodus 000??011?01010?1?0-?1-001-0----0100-001001100 ? 0 ? 000 ? 0? ? ? ? ? ? ? ? ? ? ? ? ? ? ? ? ? ? ? ? ? ? ? ? ? ? ?0? ? ? ? ? ?000110 ? ? - - 1 ?0? 111001010 ?-001?01????----?0???? 0-00?10100--1-11?---------- ?- ?? ? 0? ? 0--- ?-----0-- ? ?-- - $00-0--$ ? ? ? ? ? ? ? 1 ? ? ? ? ? ? ? ? ? ? 0 ? 0? ? ? ? 0 ? 1 ? $0--00$ ? 0

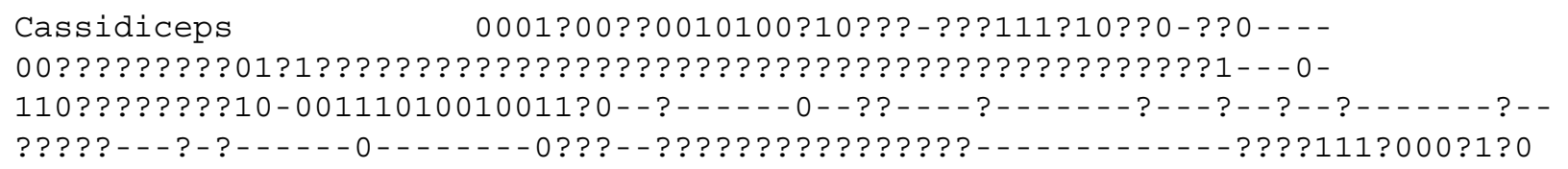

Cheiracanthus 000120011001010-?111-?-0?01110000-0-??0---0011001010 ? 01 ? ???????1???????????? 01?????????????????????1---0-

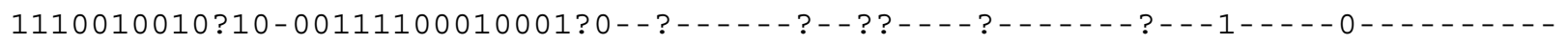
?? - ? ?-- ? - ?---- $0-------0$ ? - - - ? ? ? ? ? ? ? ? ? ? ? - - - - - - - - - ? ? ? 111 ? 00001 ? 0

Cheirolepis 000120010101012110-01-110-1100101011??10-

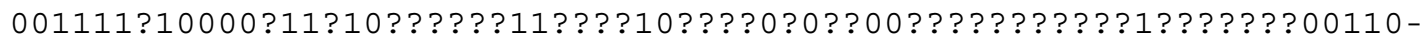
?????1???1010-00000-00---001?000?--11?0100101000011010--?10-00010010\{0 1\}00002?0?0000100100010000011000200?111100?0??????0??????10?000101?\{0 $1\} 0101$ ? $0110100--0$ ? ? 0

Chondrenchelys 11012010?00??-1-?1?1-----00----00-0-??11000011 ? 00011001110 ? $000110 ? ?-111$ ?? 0? ? ?? ?? ? ? ? 0?00110?0?0011---0-1-00110100-

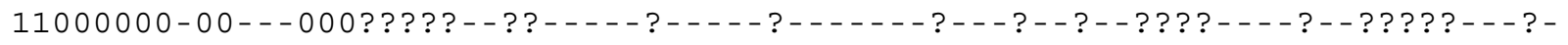
? ? ? - - - 0-? - ? ? - - ? ? 1- - ? ? ? ? ? ? ? ? ? ? ? - - ? - ? ?--- - - ? ? ? ? $100--$ ? ? ?

Cladodoides

110 ? ? ? ? ? ? ? ? ? - ? ? ? - - - - ? ? ? ? ? ? ? ? ? 111 ? - 


\section{BURROW: SCOTTISH DIPLACANTHID FISHES}

0011 ?00?? 1010 ?? 00000110101000011111110011011111 ? 0101010001 ? ? ?? ? ?? ? ? ? ? ?

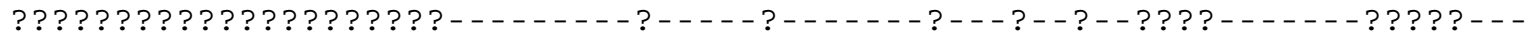

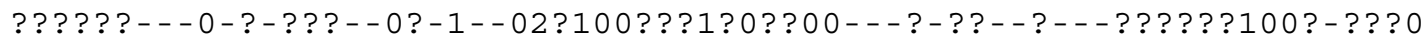

Cladoselache 1101201100-??2?-?1?1----00----10-0-?0111000110000 ? 01 ? 10?0??0111????10???11?11???????1?1?101010??10?1---0-1-

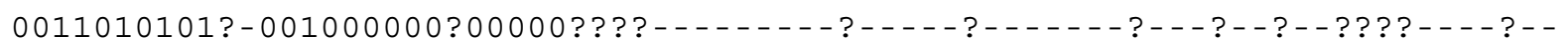

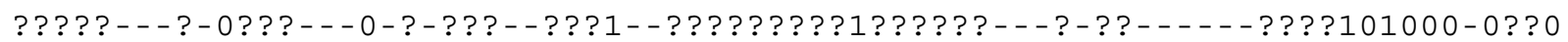

Climatius 000100010010110-?100?0-0?11100?0??0??1100000111000?0?0??1???????1??????????????????????????????????01-10100001000??10-00111011110011?000?------0-- ??---- ?------- ?---1-- ?-- ?---------

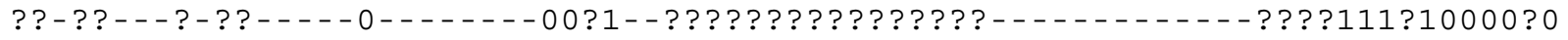

Cobelodus 1101?01??0-????-?1?1----00----10-0-0011100011 ?00010101?1??01000111101101011111110011011011001010000011---0-1-

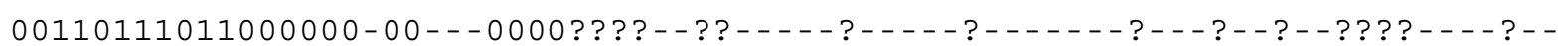

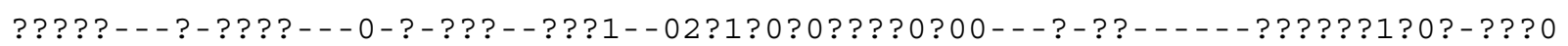

Coccosteus 000??01?0??????0?0-001111-0----0110-??10-

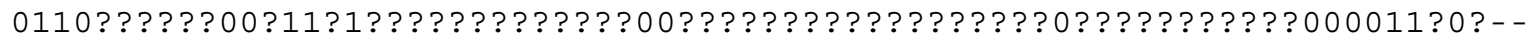
1?????1?000001-0010-100?????----?0?????0-00010101011-11?0-???0----- ?-

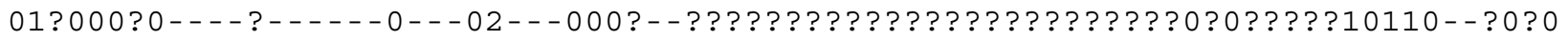

Cowralepis 000??0?????????0?0-1?-0-1-0????0110-0?10-

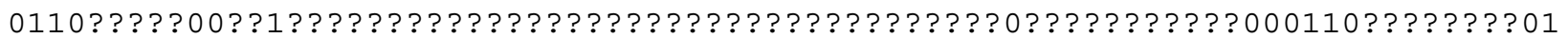

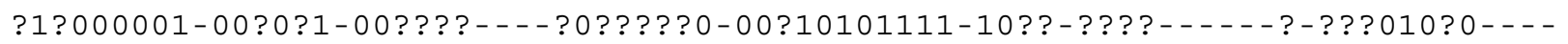

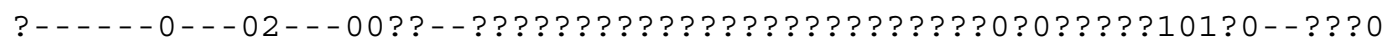

Culmacanthus ?001?00110010101?100??-1?00----0??0-??0----

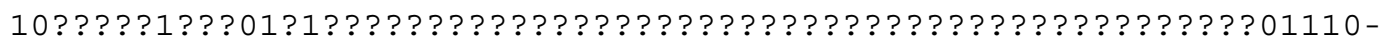
1011010????10-00111100010011??--?------0--00----0------ ?--- ?-- ?--0--------

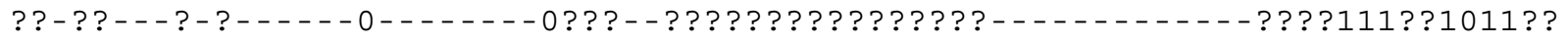

Debeerius 11012010?0???-1-?1?1----00----00-0-00101?0001 ?000?1001110?0?0?0111??-111??0?110??????10-0100100?0?00?1---0-1-

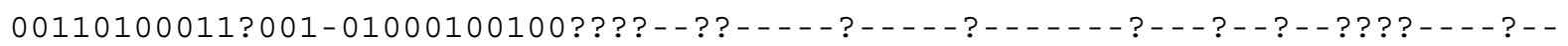
? ? ? ? - - ? - ? ? ? - - - 0 - - ? ? - - ? ? 1 - - ? ? ? ? ? ? ? ? ? ? ? - - - ? - ? - - - - - - ? ? 01 ? 1 ? 00 - ? ? ?

Diabolepis 001121 ????????1?0-?1-1?????????????? 10-

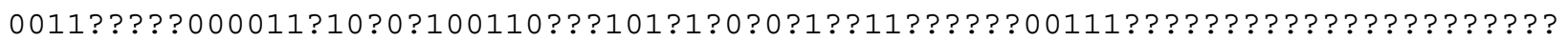
???????????????????1001????0?0011110?00101??????0-??1??? ?000?? ?11011110?11???100---11000210?????1101000??0?0?0?0??010101011??????????100?-???

Dialipina 0??1?00?011011?0?0-01-101??????0??10??1?- 
00 ? 1?? ?? ? ? ? ? 1 ? 1 ? ? ? ? ? ? ? ? ? ? ? 0 ? ? ? ? ? ? ? ? ? ? ? ? ? ? ? ? ? ? ? ? ? ? ? $00110-$

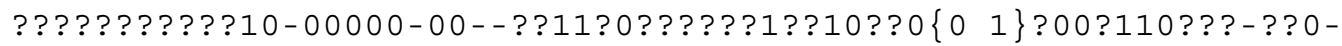
?0?? ?? ? ? ? 10 ? ? ? 01010 ? ? ? ? 110 ? ? ? 11 ? ?0? ? ? ? ? ?1 ? ? ? ? ? ? ? ? ? ? ? ? ? ? ? ? ? ? ?0 0 ? ? ? ? 01 ? $0--$ ? 0 ? 0

Dicksonosteus 00?110?1?0?????0?0-001111-0----0100-

??1??0110000????001101000001010010-00001000?00??10000-0001100000?0000001000?-1-101????000?1-?010-1??????0-- ??00?????0-00010101011-1100-???0------ ?-\{0

1\} 1 ? $01000---0-----0--02---0000--02111000001100000010000010$ ? 00000 ? ? ?110-0 ???

Diplacanthus 010100011000110?0100-?-1?00----0? ?0-??0--0-

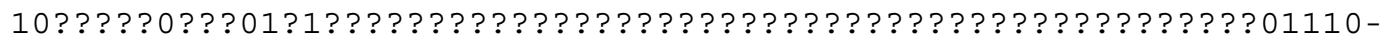

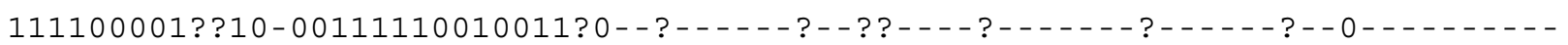
??-0?-- ? - ? - - 0

Doliodus ??01?0?10010???-?1???--0??0----???0-??11100011 ?? ?? ? 101010 ?00?00010???00??111?11?00????11??10101000?0?????????????????

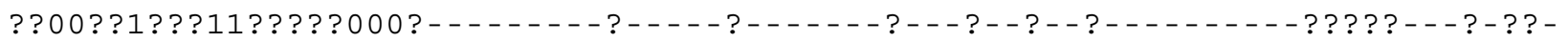

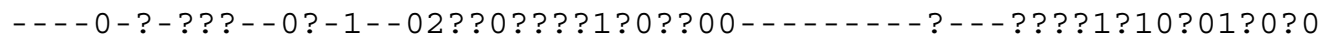

Entelognathus 000??0?? 0101??0?0-01-111-

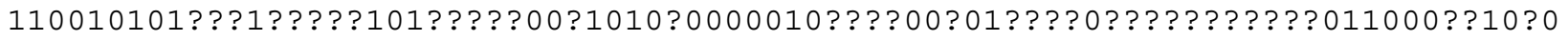

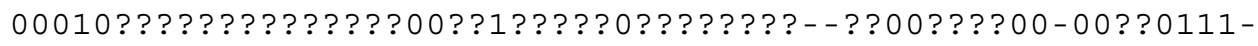

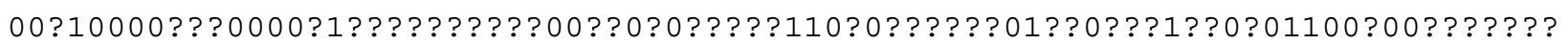
?0? ?0? ? ? ? ? 1 ? 0 ? - 0 ? ? 0

Eusthenopteron 001120010010112100-01-110-11001010101110$001111100000011110111100110110101110000 ? 1111111100$ ?0011110101000110-0-- - - 000-10-00000-00---0111?010--0110001--10100001110-?00-10??0000010????????1?????01???0??11???????? 111111000010100010001000020000111111 $010100--0 ? ? 0$

Euthacanthus 000100011001110-0100-?-0?01100100-0-??0--00011 ?? 0 ? 0?01?1???????1??????????????????????????????????? $01110-$

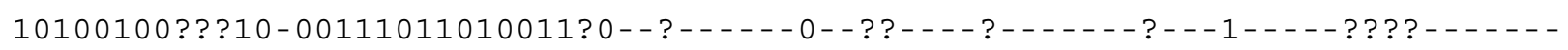
? ?-0?-- ?- ?-- 0 -

Gogonasus 0011210100101?2100-01-110-1101?010101?10001111100000011110111010110110001110000 ??1111?1????0011110101000110?? ?? ??? ? ?? ?? 0???????? 0?1?1010100?10001--10100001110-?00-10??0000010????????1??????1???0??1?????????111111000010100010001000020000?11111 ?10100--0?? 0

Guiyu 0011200101101121?0-01-110-1100101010??11-

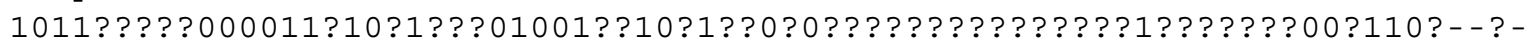




\section{BURROW: SCOTTISH DIPLACANTHID FISHES}

1?????1??001?1000010?11?000001??101001010001001110-?00?0110000000000?001000?0?101?11101111001?11011??1?301?0110???0?????010000001100 ????01100? - ??? 0

Gyracanthides_murrayi 000120110?001?--?11?-?-0-000---10-0-??0--0-

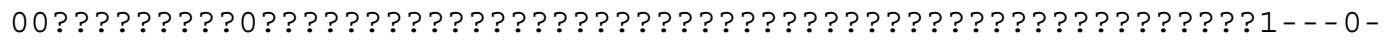

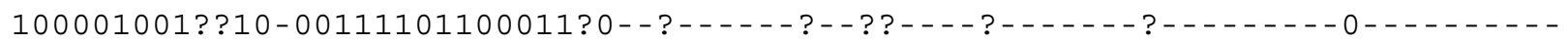

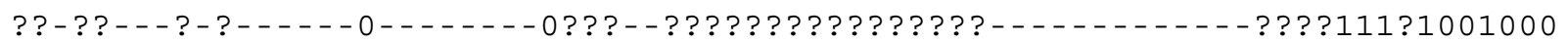

Hamiltonichthys 11012010?00?120-?110---0-00----10-0-0?11100001?0?010101?11?00??0110??-?0??1???1????????110?0?10001??011---0-1-

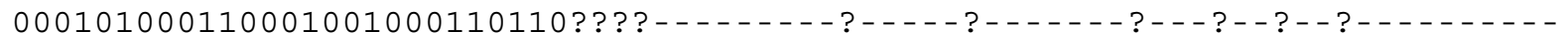
?????-- -?-??---- 0-?-???--00?1--0???0????1?0??0?------- ?-- - ???1?01000-???0

Homalacanthus 000??00??001011-0111-?--?01111000-0-??0---00110010?0?01?1??????011????1?1?????01?????????????11?????1?1-- - 0-

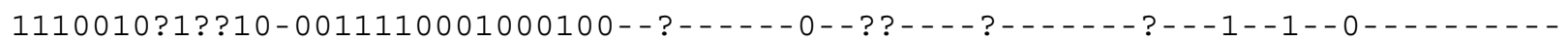

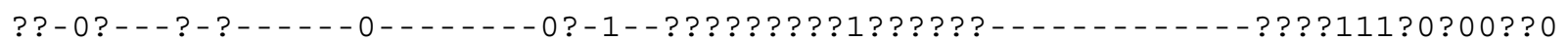

Howqualepis ?????00?0110112110-01-1101100101011?1110101111?1??00?11?10?0110?111???101?????0????????????0?1111???100 0110 - ?-???1??01110-00000-00---?011010?0110001100001000010110-?100001001 ?1100000?00000100100011?00011001200?1?110000????0?000?0??1?001111111010 ??01101?0--0???

Ischnacanthus 000120011001010-0100-?-0?01101000-0??110111011100010?0??1???????1???????????????????????????1??????? ?1- - - 0 -

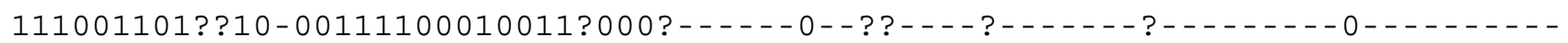

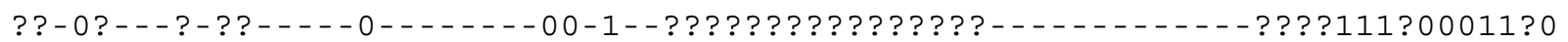

Kathemacanthus 0101000100?011?-?110-?-0?000---00-0-??0---

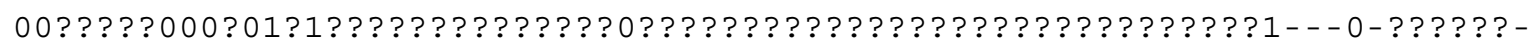

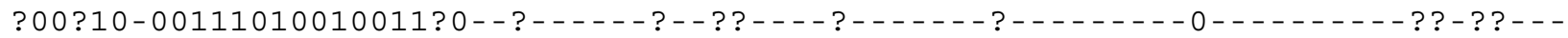

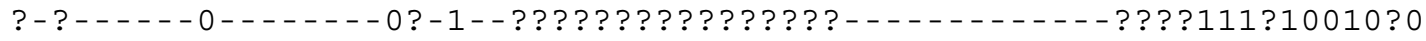

Kenichthys 001121?101101??100-01-11?-??00101010??10-011?????000011??0?1?100110???1011????0??11?????????:111??????00110-0--- -1-000???????0??????????101010??1??011110100101110-?00-

?11001000010111011121001010?100010111001110????1111000?10???0?????000020010?1? ??????100? - ????

Ligulalepis 001??0?10??????1?0-?11?????????????????????????????0?101010?1?011010010??1?000010011?1100000111???

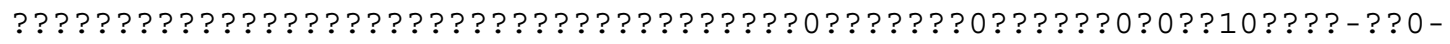

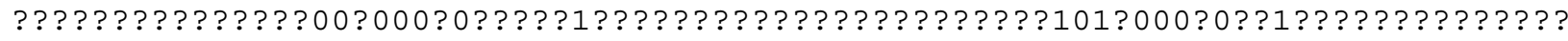
??????10??????0 
Lophosteus ?? 120?101???? 0?0-

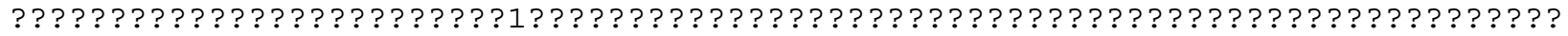
? ? ? ? ? ? ? ? ? ? ? ? ? ? ? ? ? ? ? ? ? ? ? ? ? ? ? 0? ? -

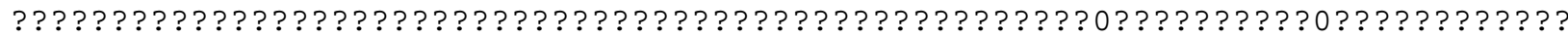
? ? ? ? ? ? ? ? ? ? ? ? ? ? ? ? ? ? ? ? ? ? ? 1 ? ? 0 ? ? 0 ? 0

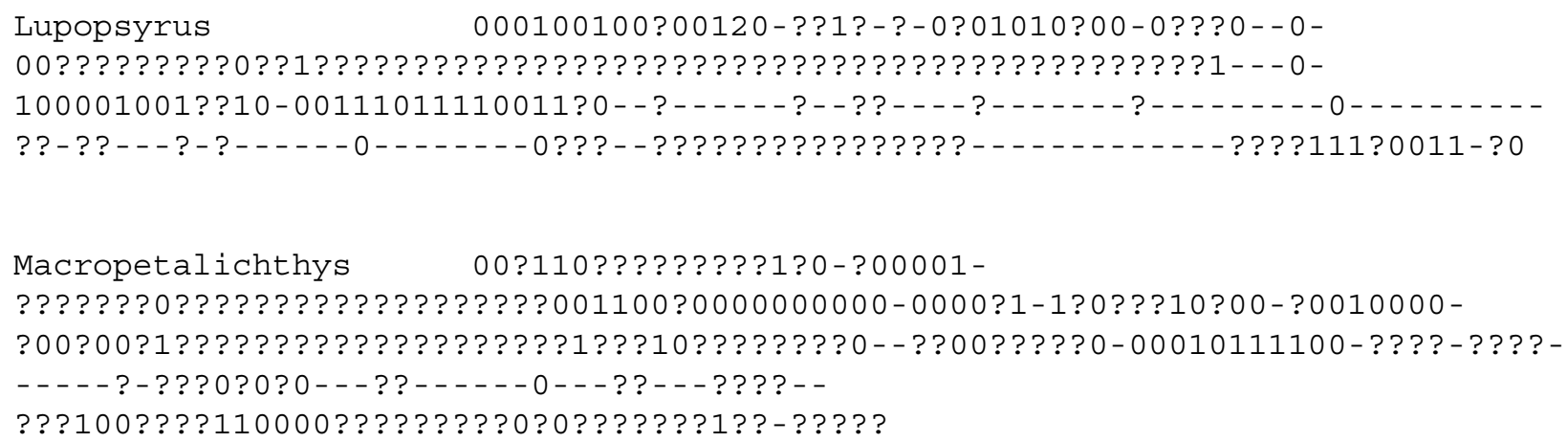

Moythomasia 001120010110112110-01-11?-1100101011?110$0011111100000111101011001111101011110000100111110000011110111000110-0----1-$ $001110000000-00--001101000110001100001000010110-? 10-$ $00010010110100001000010010011\{0$

1\}0000110002001??110000000?0000000?110001111111010100110100--0??0 


\section{BURROW: SCOTTISH DIPLACANTHID FISHES}

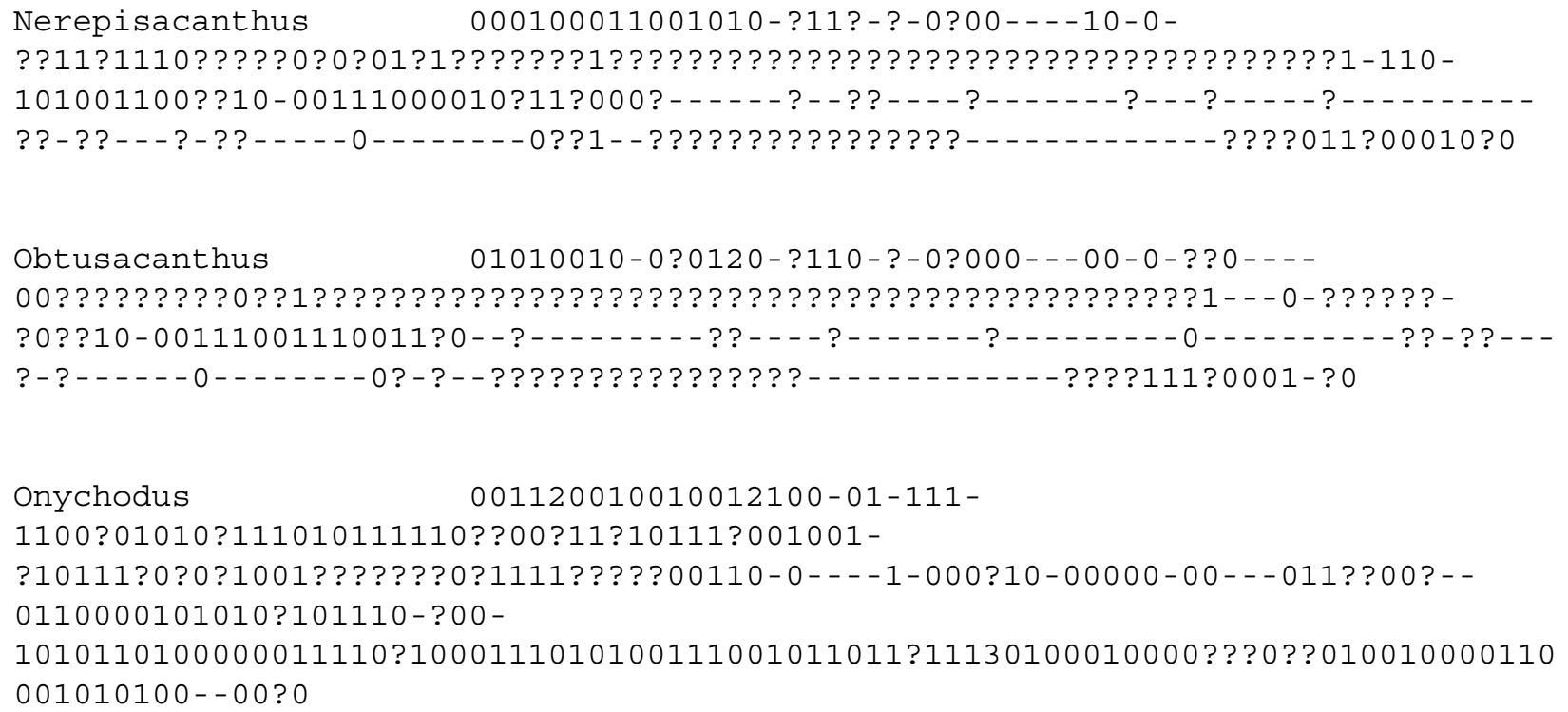




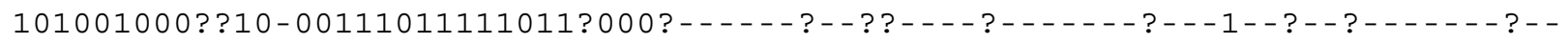

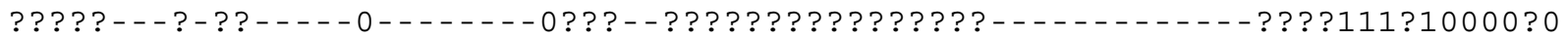

Poracanthodes $000100010001010-$ ?10???-0????????? ?0-

? ?110111011?000?0? ? ? ? ? ? ? ? ? 1 ? ? ? ? ? ? ? ? ? ? ? ? ? ? ? ? ? ? ? ? ? ? ? ? 1 - - - 0 -

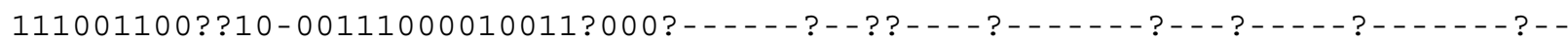

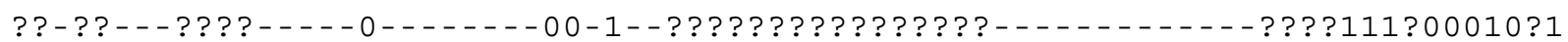

Porolepis 001121010110112100-01-110110 ?101010?1110101111100000011110?11?0011011?1011100?0??101??1????001111??01?0 0110-0---1-000?10-00000-00---?11?1010100110???10???0??00110-??0???0???000?????1?1??10???1011?11101???0?11?11111121?0001??000???0???1010???1?? ?? $1010100--$ ?? ? 0

Powichthys 001121?10110112100-01-11?-

1100 ?0101???11??011?????000011110?111001101??101?1?0?0??10??????? 0011110?0100 0110 -??????????????????0??????????101111??0000111101011011????00??10??0000101110111100010?0?101110101000110????1121000?1110?011?01011010010111 11101 ? $100--$ ???

Promesacanthus 00012001101101?-?101??--?01110000-0-? ?0----

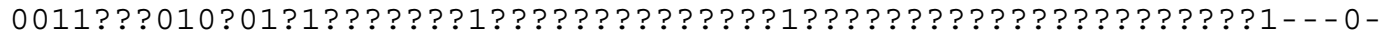

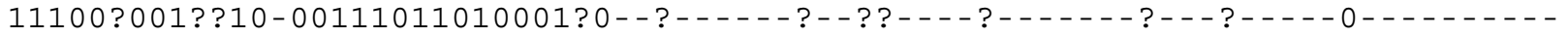

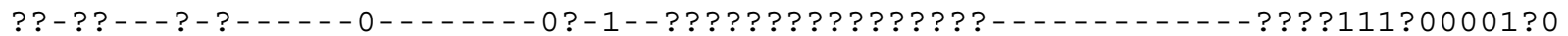

Psarolepis 001121?101?0??21?0-01-?10?? ?? ??? ?? ? 11 ?1011???? ?000011010?1?10010011?10?11?0?0?1001???100000111??????0 0?1??????-1??01?????01?10?0010????000001??10??110???0100??10-??0?1010??111000010110000?010??11101110101011011??113011011000?0001??01000000??\{0 1\}00001011000-???0

Pterichthyodes 0?0??0-1?0???010?0-00??10-0?---0100-??0--

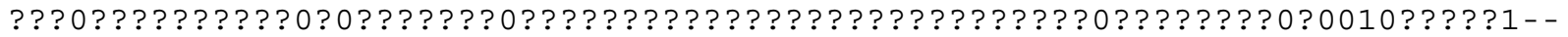

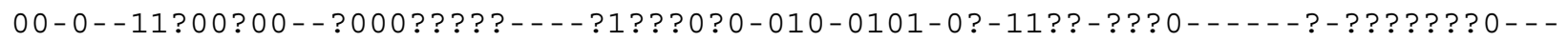

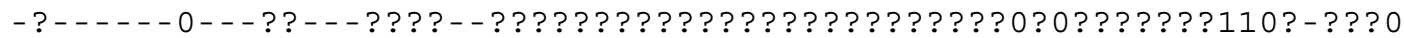

Ptomacanthus ?00100?11001110-?100??-0?01?0001??????110000110000 ?? 01?10??0????0????0????0000????????????????????10?01110-

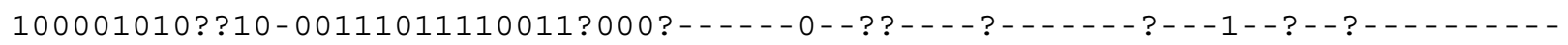

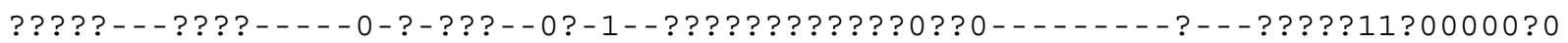

Pucapampella 110??0???????? - ?? ? - - - -

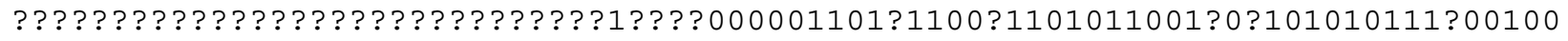

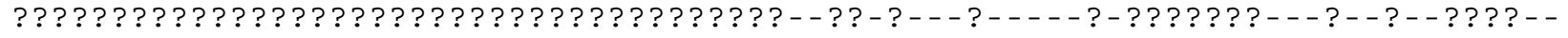

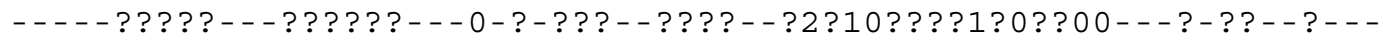
? ? ? ? ? 10 ? ? ? ? ? 


\begin{abstract}
Rhadinacanthus 010100011001010?0100-?-1?00----0??0-??0--0-

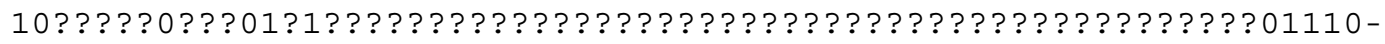

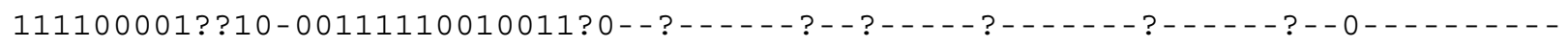

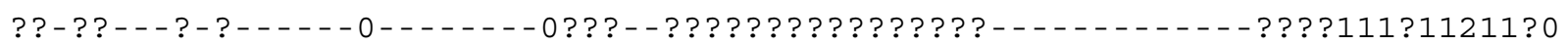

Rhamphodopsis 000??0???????0?1?0-?1-001-0----0110-??1001100 ? ? ? ? ? ?0? ? ? ? ? ? ? ? ? ? ? ? ? ? ? ? ? ? ? ? ? ? ? ? ? ? ? ? ? ? ? ? ? ? 00011 ? ?0 ? - - 1 -

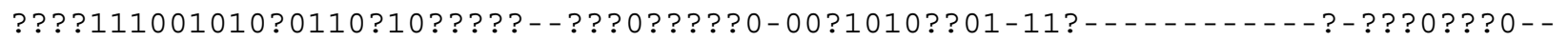

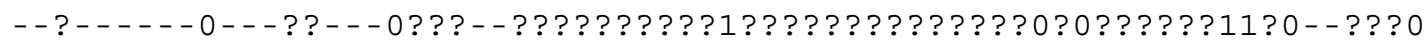

Sigaspis 0????0???0???010?0-00111?-0--- 0 010 ? ? ? ? ? ? ? ? 0 ? ? ? ? ? ? ? ? ? ? ? ? ? ? ? ? ? ? ? ? ? ? ? ? ? ? ? ? ? ? ? ? ? ? ? ? ? ? ? ? ? ? ? ? ? 000010

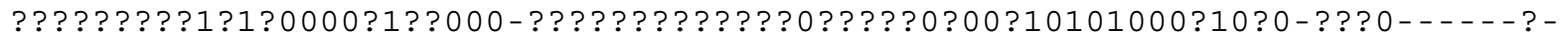

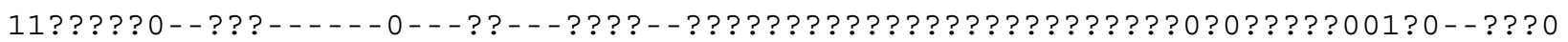

Styloichthys 001121?101101?2100-01-11?-

????????????11??011?????000011110?1?1001101?0101110? ?0?1101? ? ? ?0?001110010100 0110-0---1-000-???????0?????????00?011??1???01????00?01110-??0?1?0010??0101110111200?101??101???100100110????1121010?1110?01??0?00001011??11 1110 ? ? 100 ? - ? ? ?

Tamiobatis 1101?0?100-01??-?11?---0-???????? ????11100011?000??101??0?000001101010000111111?001???111110101000001?---

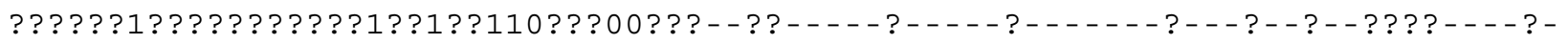

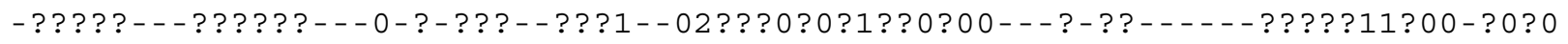

Tetanopsyrus 000120011001010-?110??-0?00----00-0-??100010010001 ? 0 ? 01 ? ? ? ? ? ? ? ? ? ? ? ? ? ? ? ? ? ? ? ? ? ? ? ? ? ? ? ? ? ? ? 1-- - $0-$

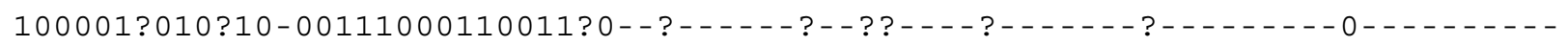
? ? ? ?-- ? - ?-- - $0------00-1--$ ? ? ? ? ? ? ? ? ? ? ? - - - - - - - - ? ? ? 111 ? 00011 ? 0

Tristychius 11012011?0-??-?-?1?1-----00----00-0-?011100001?0?010101010?000001101?-1000101?-0?001?????11101000?10011---0-1-

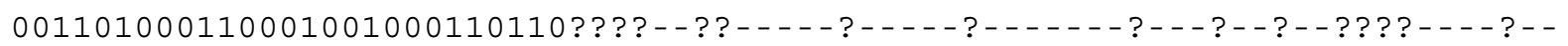

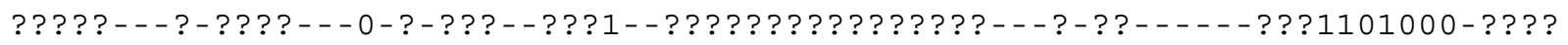

Uraniacanthus 000100011001010-?100-?-1?01000100-0-??0---

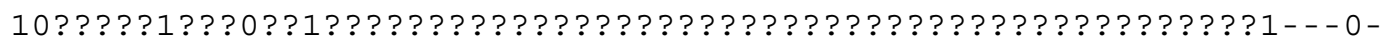

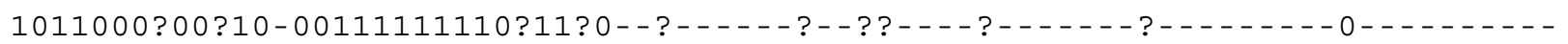
? ? ? ?-- ? - ? - -

Vernicomacanthus 000 ??0?????? 1?-??0????? ? 100 ? ?0?? ?? ? 11 ? 0000 ? ? ? ? ? ? 0? ? ? ? ? ? ? ? ? ? ? ? ? ? ? ? ? ? ? ? ? ? ? ? ? ? ? ? ? ? ?

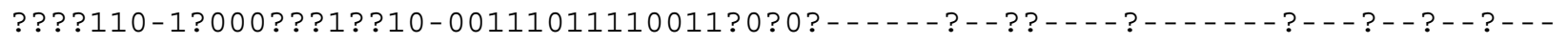

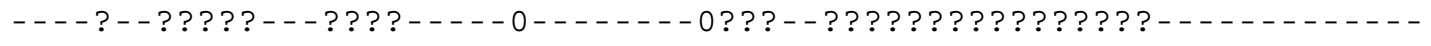


Youngolepis 001121?101101?2100-01-11?-

???? 0101???11??01111???000011110?011001101101011100?0011011111?00001111010100 0110-0---1-000-???????0?????????101111??0?00111???00101110-?00-

?11001000010111011110011010?100110101100110???11121000?1110?001001101010\{0

$1\} 1$ ? ?111110? ?1?0? - ? ? ? 